\title{
A taxonomic revision of Acanthaceae tribe Barlerieae in Angola and Namibia. Part 2
}

\author{
lain Darbyshire ${ }^{1}$ (D), Erin A. Manzitto-Tripp ${ }^{2}$ \& Frances M. Chase $\mathrm{e}^{3,4}$
}

Summary. The second part of a taxonomic revision of the tribe Barlerieae (Acanthaceae) in Angola and Namibia covers Barleria sects. Somalia and Stellatohirta. Thirty-one taxa including 27 accepted species are treated. Four new species (Barleria eburnea, B. imatensis, B. louiseana and B. thunbergiiflora), one new subspecies (B. kacondensis subsp. glabrescens) and one new variety (B. violascens var. humpatana) are described. In addition, B. taitensis S.Moore var. occidentalis S.Moore is elevated to subspecies status and B. newtonii Lindau is resurrected as a distinct species endemic to the Lubango Highlands of Angola. Full descriptions, citations of types and representative specimens, and notes on their habitat(s), ecology and biogeography are provided for each taxon. Thirteen names in Barleria are lectotypified and a neotype is selected for B. newtonii. A preliminary assessment of the conservation status and extinction risk is provided for each taxon. Of the 31 taxa enumerated, five are assessed as Endangered, two as Vulnerable, two as Near Threatened, and 13 are of Least Concern, whilst nine are currently considered to be Data Deficient. This contribution completes our revision of Barleria in Angola and Namibia, with 59 accepted species, four additional subspecies, four additional varieties and two incompletely known taxa documented in total. A remarkable $75 \%$ of the taxa are endemic or near-endemic to Angola and Namibia.

Key Words. Acanthaceae, endemic, IUCN Red List assessment, lectotype, new species, taxonomy.

\section{Introduction}

This paper presents the second and final part of the revision of Barleria L. (Acanthaceae: Acanthoideae: Barlerieae) in Angola and Namibia, continuing on from Part I of this work (Darbyshire et al. 2019a), which treated subg. Barleria and subg. Prionitis (Nees) C.B.Clarke sect. Prionitis Nees. Here, we complete the revision of species in subg. Prionitis, as redefined by Darbyshire et al. (2019b), by treating sects. Somalia (Oliv.) Lindau and Stellatohirta M.Balkwill (Table 1). For a detailed background to this study and its objectives, the reader should refer to the Introduction in Darbyshire et al. (2019a).

Sects. Somalia and Stellatohirta are challenging in the study region because many of the taxa are restricted to Angola alone and are known from very few collections (see Introduction in Darbyshire et al. 2019a for more discussion on this point), hence infraspecific variation can be difficult to assess and species delimitation is sometimes problematic. Furthermore, the paucity of collections for many taxa causes difficulties with assessment of their conservation status and extinction risk. However, given the fact that large areas of Angola are experiencing rapid habitat declines and transformation as a function of human population density and so the threats to plant species are often extreme (Mendelsohn 2019), we have tried to apply a provisional assessment for the species in question using the categories and criteria of the IUCN Red List (IUCN 2012; IUCN Standards and Petitions Committee 2019) avoiding wherever possible the Data Deficient category. However, we acknowledge that for many species, further data on range and population sizes are highly desirable.

In the discussion section, we present an overview of the distributional patterns and species richness of Barleria across Angola and Namibia, placed in the context of wider phytogeographical patterns in the region.

\section{Materials \& Methods}

The materials and methods used in this study were described in Darbyshire et al. (2019a). The numerical sequence of the species continues from that work, in which 32 species were documented. As there has been past confusion over the circumscription of Barleria alata S.Moore and B. elliptica Benoist, we cite all material seen for these species, including collections from outside the study region, although we only map the Angolan portion of their ranges. For all other species, specimen citations are restricted to the study region. For species where there is

Accepted for publication 15 August 2020. Published online 18 June 2021

1 Herbarium, Royal Botanic Gardens, Kew, Richmond, Surrey, TW9 3AE, UK. e-mail: i.darbyshire@kew.org

2 Museum of Natural History (COLO Herbarium) \& Department of Ecology and Evolutionary Biology, University of Colorado-Boulder, C105 Ramaley Hall, Campus Box 334, Boulder, CO, 80309-0350, USA.

3 National Herbarium of Namibia, Ministry of Environment, Forestry and Tourism, National Botanical Research Institute, Private Bag 13306, Windhoek, 10005, Namibia.

4 Present address: Namibian Nature Foundation, P O Box 245, Windhoek, Namibia. 
Table 1. Species treated in the present study, section to which each belongs, geographical range and conservation assessments assigned herein. Under range, "Endemic" status noted for plants endemic to either Angola, Namibia, or both.

\begin{tabular}{|c|c|c|c|}
\hline Species & Section & Range & Conservation Assessment \\
\hline B. alata & Somalia & Angola, Widespread & Least Concern \\
\hline B. antunesii & Somalia & Angola (Endemic) & Data Deficient \\
\hline B. benguellensis & Somalia & Angola (Endemic) & Data Deficient \\
\hline B. buddleoides & Stellatohirta & Angola (Endemic) & Endangered \\
\hline B. eburnea & Somalia & Angola (Endemic) & Least Concern \\
\hline B. elliptica & Somalia & Angola, D. R. Congo & Data Deficient \\
\hline B. gossweileri & Somalia & Angola (Endemic) & Least Concern \\
\hline B. grootbergensis & Somalia & Namibia (Endemic) & Least Concern \\
\hline B. imatensis & Somalia & Angola (Endemic) & Data Deficient \\
\hline B. kacondensis subsp. kacondensis & Somalia & Angola (Endemic) & Near Threatened \\
\hline B. kacondensis subsp. glabrescens & Somalia & Angola (Endemic) & Endangered \\
\hline B. lancifolia & Somalia & Namibia, Widespread & Least Concern \\
\hline B. louiseana & Somalia & Angola (Endemic) & Endangered \\
\hline B. lugardii & Somalia & Namibia, Widespread & Least Concern \\
\hline B. mackenii & Somalia & Angola, Namibia, Widespread & Least Concern \\
\hline B. matopensis & Somalia & Namibia, Widespread & Least Concern \\
\hline B. newtonii & Somalia & Angola (Endemic) & Endangered \\
\hline B. pabularis & Somalia & Angola (Endemic) & Least Concern \\
\hline B. phaylopsis & Somalia & Angola, D. R. Congo, Zambia & Least Concern \\
\hline B. polyneura & Somalia & Angola (Endemic) & Near Threatened \\
\hline B. salicifolia & Stellatohirta & Angola (Endemic) & Data Deficient \\
\hline B. stellato-tomentosa & Stellatohirta & Angola (Endemic) & Vulnerable \\
\hline B. subglobosa & Stellatohirta & Angola (Endemic) & Vulnerable \\
\hline B. taitensis subsp. occidentalis & Stellatohirta & Angola, Namibia (Endemic) & Least Concern \\
\hline B. thunbergiiflora & Somalia & Angola (Endemic) & Least Concern \\
\hline B. violacea & Somalia & Namibia (Endemic) & Data Deficient \\
\hline B. violascens var. violascens & Somalia & Angola (Endemic) & Least Concern \\
\hline B. violascens var. humpatana & Somalia & Angola (Endemic) & Endangered \\
\hline B. welwitschii & Somalia & Angola (Endemic) & Data Deficient \\
\hline B. sp. (= Boss s.n.) & Somalia & Angola (?Endemic) & Data Deficient \\
\hline B. sp. (= Teixeira s.n.) & Somalia & Angola (?Endemic) & Data Deficient \\
\hline
\end{tabular}

considerable variation outside of the study region, most notably in B. matopensis S.Moore and B. taitensis S.Moore, we include notes on and keys to the variation across their respective ranges.

Since the publication of Darbyshire et al. (2019a), a major, multi-author volume on the biodiversity of Angola has been published (Huntley et al. 2019a), which provides useful information relevant to the current study. In particular, the chapters on the flora of Angola (Goyder \& Gonçalves 2019) and landscape changes in Angola (Mendelsohn 2019) have informed the current work.

Some recent collections by D. J. Goyder (K) from Angola are housed in the fledgling herbarium of the government's Instituto Nacional da Biodiversidade e Áreas de Conservação, which is not yet listed on Index Herbariorum; this is abbreviated to 'INBAC' (following Darbyshire \& Goyder 2019).

The species distribution maps were produced using QGIS version 2.14.4, whilst the species richness maps were produced in QGIS version 3.10 (available online at https://www.qgis.org/en/site/forusers / download.html). Species richness is mapped using a grid with each square measuring half a degree of latitude and longitude.

\section{Taxonomic Account continued}

To assist with understanding of the descriptions and keys, the reader should refer to the notes on terminology, presented in Darbyshire et al. (2019a: 6 ). The key to infrageneric taxa in Barleria can be found in Darbyshire et al. (2019a: 7).

\section{Barleria subg. Barleria (addendum)}

Since the publication of the first part of this revision, photographs have become available of two of the species of subgen. Barleria that were not previously illustrated by colour images: B. elegans S.Moore ex C.B.Clarke subsp. elegans and B. crabbeoides I.Darbysh., and better photographs have become available for B. rupicola I.Darbysh. These are included here in Fig. 1. As B. crabbeoides is a rare species that was newly described in Darbyshire et al. (2019a), we include the details of the additional collection below.

21. Barleria crabbeoides I.Darbysh. (in Darbyshire et al. 2019a: 57). Fig. 1C \& D.

ADDITIONAL COLLECTION STUDIED. ANGOLA. Huíla, Tundavala, fl. 23 Feb. 2018, F. Lages, (photo. 

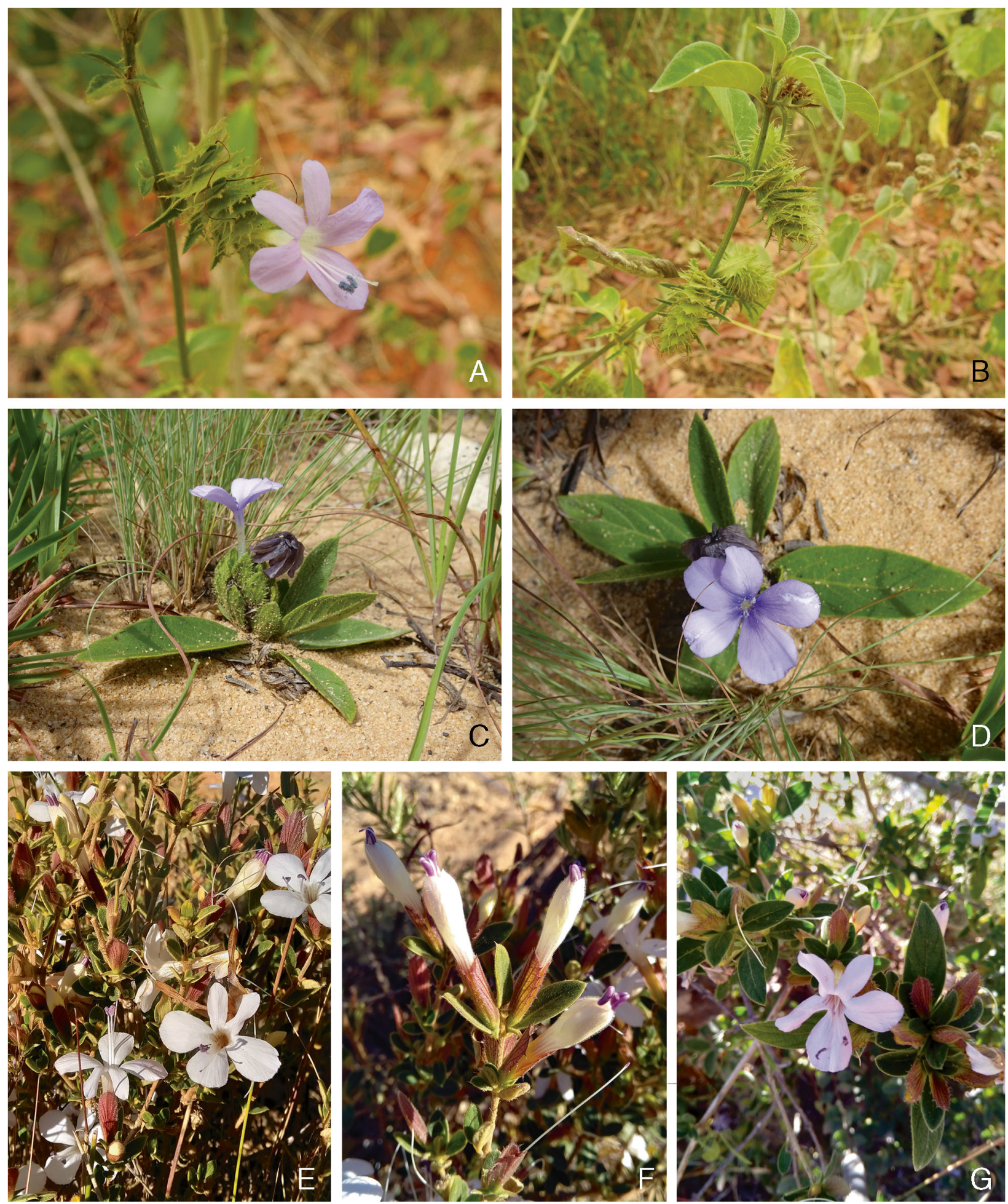

Fig. 1. A - B Barleria elegans subsp. elegans, Quissama, Angola: A inflorescence and flower; B branch with inflorescences. C - D Barleria crabbeoides, Tundavala, Angola: C habit; D flower. E - G Barleria rupicola, Lubango, Angola: E, G flowers, F flower buds. PHOTOS: A, B P. BEJA; C, D F. LAGES; E - G F. LAGES.

record); https://www.inaturalist.org/observations/ 33554726; https://www.inaturalist.org/observations/ 33554727.
NOTES. With the additional information provided from the above field observation, a full conservation assessment of this species has been possible and it has been 
assessed as Endangered - EN B1ab(iii)+2ab(iii) (Darbyshire et al. 2020b).

Barleria subg. Prionitis (Nees) C.B.Clarke (1884: 482) (continued)

Barleria sect. Somalia (Oliv.) Lindau (1895a: 315); Clarke (1899: 142); Obermeyer (1933: 130); Balkwill \& Balkwill (1997: 563); Darbyshire \& Ndangalasi (2009: 122 - 134); Darbyshire (2010: 387; 2015: 92).

Somalia Oliv. (Oliver 1886: t.1528).

Barleria subgen. Eu-Barleria "Glabratae" sensu Clarke (1899: 143), pro parte, excl. B. marginata.

Barleria sect. Cavirostrata M.Balkwill (in Balkwill \& Balkwill

1998: 110); Balkwill \& Balkwill (1997: 566); Darbyshire

(2009: 601 - 611; 2010: 385; 2015: 91).

Axillary spines absent. Indumentum (in our region) simple and/or of biramous hairs, these medifixed or "anvil-shaped" (i.e. with one long arm and one short arm, the latter sometimes reduced to a swelling), or plants glabrous. Leaves often densely pale-hairy in bud but later glabrescent. Inflorescences single-flowered or dichasial cymes, either axillary, then bracts foliaceous, or aggregated into terminal thyrses, then bracts \pm modified. Calyx lobes with margins entire. Corolla white, blue, pink or purple, rarely yellow, sometimes with darker guidelines; limb variously in " $4+1$ ", " $2+3$ ", " $1+3$ " or subregular configuration. Staminodes 2 or 3, antherodes absent. Stigma linear, often curved, apex entire or minutely bilobed. Capsule drying (pale) brown, \pm laterally compressed, fertile portion orbicular or obovate, \pm abruptly narrowed into a prominent solid or basally hollow apical beak; lateral walls remaining attached to flanks at dehiscence, septum with a membranous portion above the retinacula, elsewhere woody; seeds 2 or 4, discoid or lenticular, with dense cream or buff-coloured, woolly hygroscopic hairs or these rarely absent (not in our region).

Section Cavirostrata is included within sect. Somalia here, as per the revised circumscription proposed by Darbyshire et al. (2019a); it was previously separated by having four-seeded capsules (see Balkwill \& Balkwill 1997; Darbyshire 2009) but these four-seeded species are nested within sect. Somalia. In our region, there are a number of four-seeded species (e.g. B. kacondensis and allies, B. pabularis and allies) that are otherwise very similar to typical two-seeded species of sect. Somalia. Furthermore, the group of species within the B. lancifolia-mackenii complex (spp. 44 - 49 below) appear to be somewhat intermediate, in that they are two-seeded but the capsule has a more tapered base than in typical sect. Somalia and there is some free locular capacity towards the base, suggesting that the two extra ovules abort rather late in these species. Molecular evidence demonstrates that the B. lancifoliamackenii complex is allied to former members of sect. Cavirostrata (Darbyshire et al. 2019b; Comito 2019).

Under this revised circumscription, sect. Somalia comprises c. 65 species. It is most diverse in east and northeast Africa and in Angola, but is also recorded in Madagascar, Arabia and the Indian Subcontinent, with 24 species documented below in Angola and Namibia.

\section{Key to species of Barleria sect. Somalia in Angola and Namibia}

1 Corolla 4-lobed due to fusion of the pair of adaxial lobes into a single emarginate lobe . . . . . . 43. B. lugardii Corolla 5-lobed, pair of adaxial lobes free for as long as the lateral lobes or (rarely) fused for up to half their

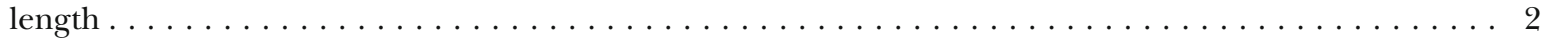

2 Outer calyx lobes either with eglandular hairs only or glabrous $\ldots \ldots \ldots \ldots \ldots \ldots$ Outer calyx lobes with at least some glandular hairs present and usually conspicuously glandular-pubescent,

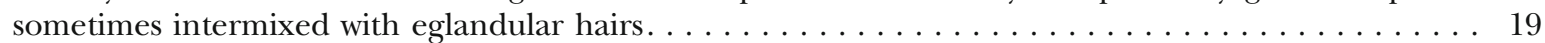

3 Outer calyx lobes glabrous externally or at most with sparse and inconspicuous hairs along margin and/or midrib . . . 4 Outer calyx lobes conspicuously hairy externally with eglandular hairs numerous throughout or concentrated along

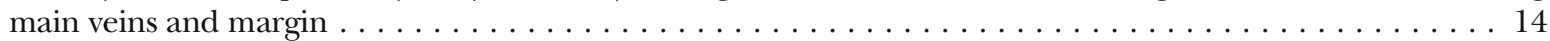

4 Dwarf perennial herb with stems to $20 \mathrm{~cm}$ tall; calyces small, posterior lobe broadly ovate-elliptic, up to $14 \times 10 \mathrm{~mm}$,

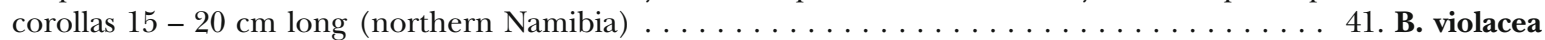

Plant habit various but often taller than $20 \mathrm{~cm}$, calyces larger, posterior lobe variously shaped, $17-36.5 \times 9-$

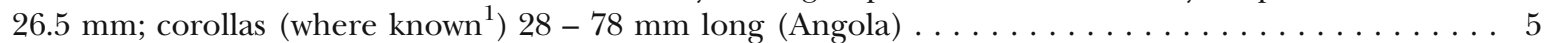

5 Leaves cordate and amplexicaul at base; corolla $57-78 \mathrm{~mm}$ long, white with a line of dark purple-brown spots along the centre of each lobe $\ldots \ldots \ldots \ldots \ldots \ldots \ldots \ldots \ldots \ldots \ldots \ldots \ldots \ldots \ldots \ldots \ldots$. newtonii

Leaves with base variously attenuate or cuneate to rounded or shallowly cordate but not amplexicaul; corolla (where known) $28-53 \mathrm{~mm}$ long, without a line of dark spots along the centre of each lobe . . . . 6 6

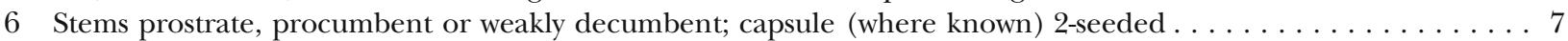
Stems erect or decumbent; capsule (where known) 4 -seeded $\ldots \ldots \ldots \ldots \ldots \ldots$

\footnotetext{
${ }^{1}$ Corolla not known in B. sp. (= Boss s.n.) and B. sp. (= Teixeira s.n.).
} 
7 Largest leaves ovate to ovate-elliptic or broadly so, $1.4-3.7 \mathrm{~cm}$ wide, l:w ratio $1.3-3: 1 \ldots \ldots$

Largest leaves variously narrowly elliptic, narrowly oblong, lanceolate or linear-lanceolate, up to $2 \mathrm{~cm}$ wide, $1: \mathrm{w}$

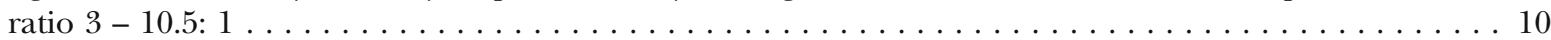

8 Largest leaves with base cuneate or attenuate, l:w ratio 2.1 - 3: 1; outer calyx lobes with base rounded or subcordate;

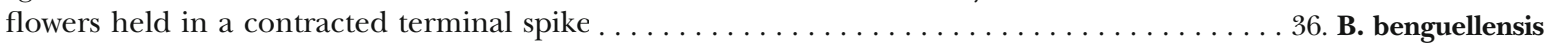

Largest leaves with base rounded, subcordate or obtuse, l:w ratio 1.3 - 2.3: 1; outer calyx lobes with base cordate or shallowly so; flowers held singly in distal axils, not contracted into a terminal spike . . . . . . 9

9 Leaves 2.7 - $3.8 \mathrm{~cm}$ long; corolla lilac, lobes equal in length to or slightly shorter than the tube, lateral lobes

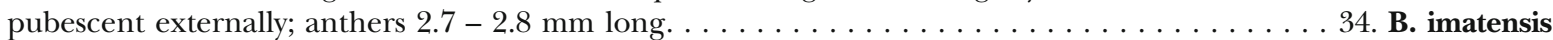

Leaves 4.3 - $7 \mathrm{~cm}$ long; corolla white or cream-coloured sometimes with a violet throat, lobes slightly longer than the tube, all lobes glabrous externally; anthers $3.4-3.8 \mathrm{~mm}$ long . . . . . . . . 35. B. polyneura

10 Outer calyx lobes ovate or ovate-rhombic, base rounded or shallowly cordate; flowers axillary in distal leaf axils or together

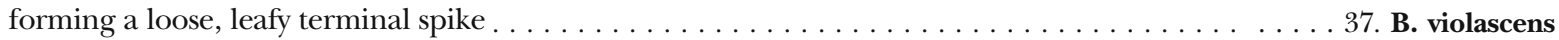
Outer calyx lobes elliptic-rhombic, base cuneate or attenuate; flowers held in a well-defined contracted terminal spike (imperfectly known species, possibly a form of B. violascens) . . . . . . . . . . 38. B. sp. (= Boss s.n.)

11 Leaves ovate or ovate-elliptic, l:w ratio \pm 2: 1; single-flowered cymes aggregated into a dense terminal spike; outer

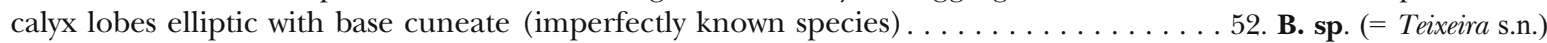

If leaves as above then single-flowered cymes held in loose terminal spikes, not densely aggregated, and outer

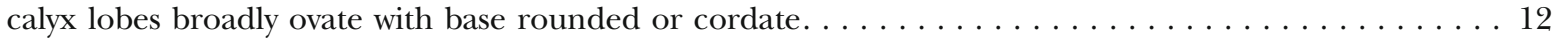

12 Corolla 28 - $31 \mathrm{~mm}$ long including tube $10.3-11.7 \mathrm{~mm}$ long; staminal filaments $6-8 \mathrm{~mm}$ long, glabrous except for short glandular hairs at base $\ldots \ldots \ldots \ldots \ldots \ldots \ldots \ldots \ldots \ldots \ldots \ldots$. eburnea

Corolla 33 - $53 \mathrm{~mm}$ long including tube 13.5 - $19 \mathrm{~mm}$ long; staminal filaments 12.5 -18.5 mm long, with subsessile glands throughout or for $2 /{ }_{3}$ of their length in addition to glandular hairs at base . . . . 13

13 Corolla white or tinged pink; leaves lanceolate to oblong-elliptic, l:w ratio $3.3-8.4$ : 1; posterior calyx lobe with apex

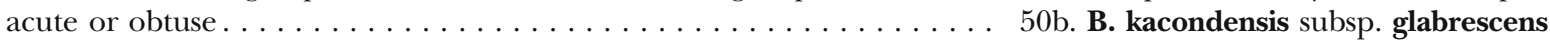

Corolla blue-lilac; leaves ovate-elliptic to obovate, l:w ratio $1.3-2.5$ : 1; posterior calyx lobe with apex broadly

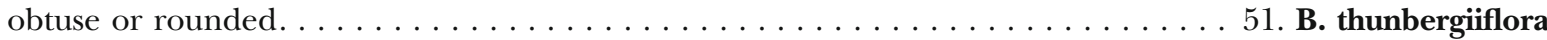

14 Corolla glabrous externally; mature stems lacking a white-puberulous indumentum. . . . . . . . . . 15

Corolla eglandular- and glandular-pubescent externally at least on the lateral lobes, if only sparsely so then mature stems white due to dense white-puberulous indumentum $\ldots \ldots \ldots \ldots \ldots$

15 Outer calyx lobes broadly obovate or posterior lobe elliptic, apex of posterior lobe rounded, external surfaces finely puberulous; leaves (oblong-) elliptic or somewhat obovate, l:w ratio $(1.75$-) $2.2-3.5: 1 \ldots$. . . 56. B. louiseana

Outer calyx lobes ovate, ovate-rhombic or elliptic, apex of posterior lobe acute, attenuate or rarely obtuse, surfaces either antrorse- or patent-pubescent; leaves narrow, lanceolate, oblong-lanceolate or oblong-elliptic,

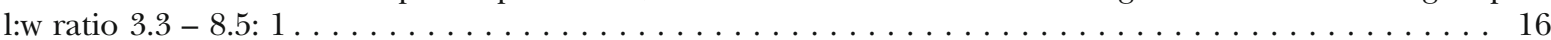

16 Staminal filaments glabrous except for short glandular hairs at base; outer calyx lobes shortly antrorse-pubescent throughout; corolla throat only narrowly widened, not funnel-shaped . . . . . . . . . 39. B. antunesii

Staminal filaments with subsessile glands throughout or for $2 / 3$ of their length in addition to glandular hairs at base; outer calyx lobes pubescent with spreading hairs, primarily on the main veins and margin; corolla throat markedly funnel-shaped. . . . . . . . . . . . . . . . . 50a. B. kacondensis subsp. kacondensis

17 Mature stems usually glabrescent, not densely white-puberulent; corolla throat campanulate, limb in conspicuous " $4+1$ "

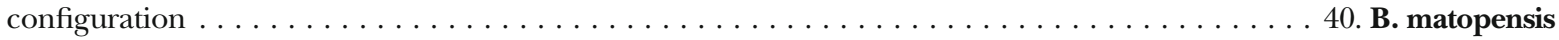

Mature stems densely white-puberulent, giving a velutinous texture; corolla throat funnel-shaped to weakly so, limb

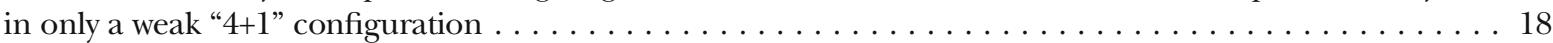

18 Outer calyx lobes broadly ovate with base (sub)cordate, \pm strongly accrescent in fruit . . . . . . 44. B. mackenii Outer calyx lobes (ovate-) elliptic with base cuneate, not strongly accrescent in fruit (rare forms lacking glandular hairs $\ldots \ldots \ldots \ldots \ldots \ldots \ldots \ldots \ldots \ldots \ldots \ldots \ldots$. . . lancifolia

19 Mature stems white and velutinous in texture due to dense white-puberulent indumentum . . . . . . . . . 20

Mature stem indumentum variable or glabrescent; if puberulent then hairs colourless or grey so that the stems

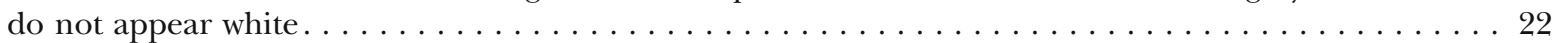

20 Inflorescence a well-defined terminal spike, dense and with the bracts and bracteoles held erect and largely hiding the calyces at least in the distal portion of the spike; calyces elliptic or often subrhombic with

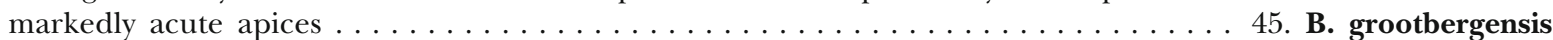

Inflorescence a loose and \pm lax terminal spike or thyrse, or cymose units axillary; bracts and bracteoles usually spreading, the calyces clearly exposed throughout; calyces elliptic or ovate-elliptic, with obtuse

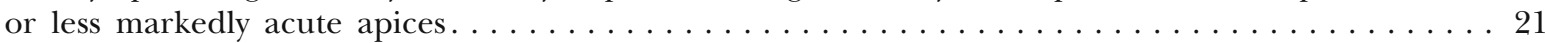


21 Indumentum of mature stems, young leaves, bracts, bracteoles and calyces including biramous (medifixed and/or

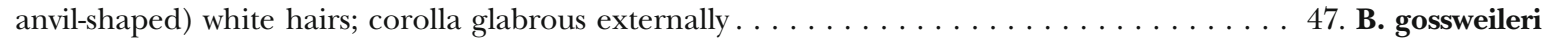

Plants lacking biramous hairs throughout; corolla glandular- and eglandular-pubescent externally mainly on

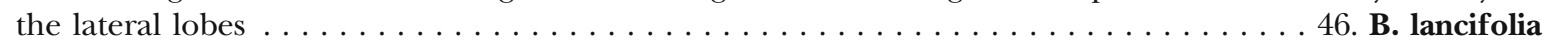

22 Dwarf suffruticose herbs with unbranched or few-branched erect, decumbent or procumbent stems $5-30 \mathrm{~cm}$ tall

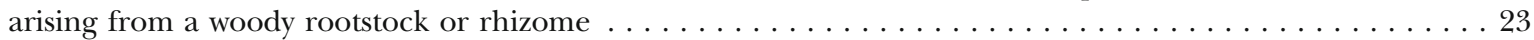

Perennial herbs or shrubs, usually larger than $30 \mathrm{~cm}$ tall (but rarely down to $10 \mathrm{~cm}$ tall), without a woody

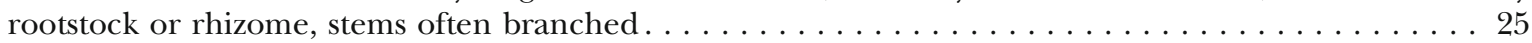

23 Corolla in "2+3" configuration, adaxial pair of lobes oblanceolate to subulate, $1.5-4$ mm wide, sometimes partially fused; outer calyx lobes narrowly oblong, lanceolate or subulate, $1.5-2.7 \mathrm{~mm}$ wide; ovary and capsule

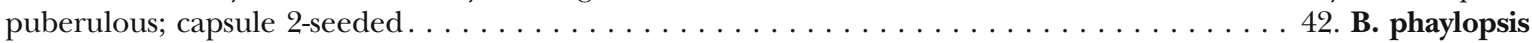

Corolla limb subregular, adaxial pair of lobes broadly obovate, 12.5 - $16 \mathrm{~mm}$ wide; outer calyx lobes oblong-ovate to obovate, 8 - $18 \mathrm{~mm}$ wide; ovary and (where known) capsule glabrous; capsule (where known) 4-seeded 24

24 Outer calyx lobes oblong-ovate, $26-30 \times 14.5-18 \mathrm{~mm}$, with more sparse glandular hairs between the veins externally; bracts all leafy, oblanceolate to oblong-elliptic, $27-56 \times 11.5-21 \mathrm{~mm} \ldots \ldots$. . . 54. B. pabularis

Outer calyx lobes obovate or obovate-elliptic, $18-25 \times 8-16 \mathrm{~mm}$, with numerous glandular hairs and short eglandular hairs between the veins externally; bracts above basal-most pair oblanceolate, $19-31 \times 6-9$

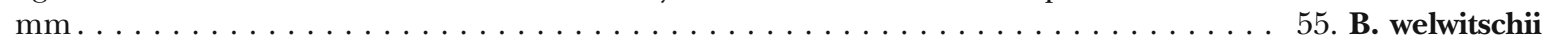

25 Ovary and capsule glabrous or rarely with few eglandular hairs towards apex; young stems with fine antrorseappressed or tomentellous hairs; outer calyx lobes with indumentum as stems but interspersed with

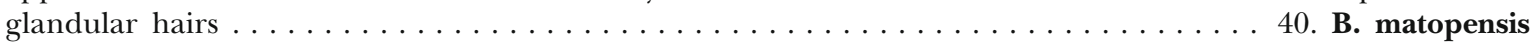

Ovary and capsule mixed glandular- and eglandular-puberulous; young stems mixed eglandular- and glandular-puberulous throughout or in two opposite lines, or largely glabrous; outer calyx lobes glandular- and eglandular-pubescent to -puberulous, often with strigulose hairs on main veins and

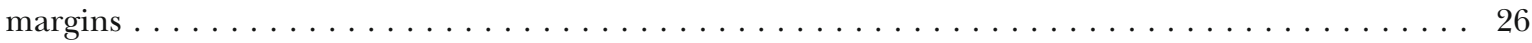

26 Outer calyx lobes elliptic or lanceolate; unwinged portion of petiole $3-32 \mathrm{~mm}$ long or blade subsessile, leaf base more gradually attenuate above cuneate wing-like extension; mature stems usually puberulent at least towards base, more rarely these hairs absent then with only scattered hispid hairs; corolla with only a weak " $4+1$ " configuration, abaxial lobe offset by $2-3.5 \mathrm{~mm} \ldots \ldots \ldots \ldots \ldots \ldots \ldots \ldots \ldots$. elliptica

Outer calyx lobes obovate; unwinged portion of petiole $(7-) 20-70 \mathrm{~mm}$ long, distal portion narrowly winged then attenuate or often more abruptly expanded into a rounded base above the winged portion; mature stems soon-glabrescent; corolla with a conspicuous " $4+1$ " configuration, abaxial lobe

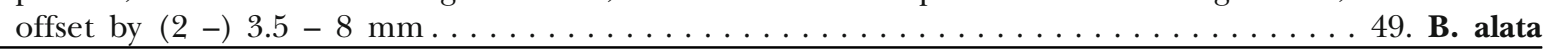

33. Barleria newtonii Lindau (1895b: 117). Types: Angola, Serra Chella bei Lobango [Lubango], fl. July 1883, Newton 193 (holotype B $\dagger$ ); Moçâmedes, Serra de Chela, near the summit, fl. 17 May 1937, Exell Ẽ Mendonça 2083 (neotype BM! [BM001010589], selected here; isoneotype $\mathrm{P}^{*}$ [P02894880]).

Barleria calophylla sensu auctt., non Lindau (1894: 17):

Clarke (1899: 159), pro parte quoad Newton 193; Benoist (1950: 17); Klopper et al. (2006: 4) pro parte; Makholela (2008: 21).

Perennial herb to c. $50 \mathrm{~cm}$ tall; stems reddish-brown, young stems with fine white spreading or antrorse hairs on two sides immediately below nodes and along nodal line, soon glabrescent; mature stems stout, subterete, to $5 \mathrm{~mm}$ diam. Leaf buds densely pubescent with cream-coloured hairs. Leaves sessile, blade lanceolate to narrowly oblonglanceolate, $8-13.5 \times 1.6-3.5 \mathrm{~cm}$ (l:w ratio $3.2-5.5$ : 1 ), base cordate and amplexicaul, margin entire, apex acute to obtuse, apiculate, surfaces glabrous; lateral veins $7-8$ pairs. Inflorescences of single-flowered subsessile cymes in upper axils and terminal, together forming a loose spike; bracts as leaves but rapidly reducing up the stem, typically $25-48 \times 10-19 \mathrm{~mm}$; bracteoles pale yellow-green, minute, lanceolate, $1.5-4.5 \times 0.8-2 \mathrm{~mm}$, conduplicate, surfaces with minute sessile glands; pedicels $4-6 \mathrm{~mm}$ long, with white antrorse hairs on two opposite sides at least towards base. Calyx green or pinkish-brown, somewhat accrescent; anterior lobe ovate, $25-42 \times 15-27.5$ $\mathrm{mm}$, base cordate, apex notched with two triangular lobes $1.5-5 \mathrm{~mm}$ long, external surface glabrous; posterior lobe as anterior lobe but $36-57 \times 17.5-34$ $\mathrm{mm}$, apex acute-apiculate; lateral lobes straw-coloured, linear-lanceolate, 11 - $12 \mathrm{~mm}$ long, margin with fine antrorse hairs. Corolla 57 - $78 \mathrm{~mm}$ long, white with a line of purple-brown spots running along centre of each lobe and into mouth, glabrous externally; tube $21-27 \mathrm{~mm}$ long, $4-5 \mathrm{~mm}$ in diam. in basal portion, gradually expanded above insertion point of stamens, mouth 7 $11 \mathrm{~mm}$ in diam.; limb in " $4+1$ " configuration, abaxial lobe offset by 6-11 mm, elliptic, $24-29 \times 17 \mathrm{~mm}$; lateral lobes elliptic or obovate-elliptic, $27-39 \times 19-25 \mathrm{~mm}$; adaxial lobes narrower, $25-37 \times 15 \mathrm{~mm}$. Stamens inserted c. $8 \mathrm{~mm}$ from base of corolla tube; filaments $26-41 \mathrm{~mm}$ 
long; anthers 4 - $5.6 \mathrm{~mm}$ long; lateral staminodes c. $1.5 \mathrm{~mm}$ long. Pistil glabrous; stigma linear, $0.8-1.4 \mathrm{~mm}$. Capsule not seen.

DISTRIBUTION. Endemic to Southwest Angola (Huíla and Namibe Provs.); Map 1.

ADDITIONAL COLLECTIONS STUDIED. ANGOLA. Moçâmedes, Humbia - Chela Hills, fl. 20 May 1937, Gossweiler 10962 (BM!, K!, P*); a 40 km de Sá da Bandeira [Lubango] na estrada para Vila Arriaga [Bibala], fl. 7 June 1962, Figueira de Sousa 222 (LUBA!).

HABITAT \& ECOLOGY. Gossweiler recorded this species from dry forest ("hiemisilva"); no other habitat data are available; it occurs at c. $950-1900 \mathrm{~m}$ elevation. It has so far been recorded only from the Lubango Highlands of the Huíla Plateau.

CONSERVATION STATUS. Based on current evidence, this species is endemic to the Lubango Highlands where it is apparently scarce, as it has only rarely been collected despite its large, showy corollas and despite this area being well botanised relative to other parts of Angola. This area has been subject to extensive natural habitat loss and intact vegetation is now largely restricted to steeper slopes and gullies. The main drivers of habitat loss in Huíla (as elsewhere in Angola) are agricultural activities, increased frequency of fire, fuelwood extraction, charcoal production and urban development (Chisingui et al. 2018). With an extent of occurrence (EOO) of c. $200 \mathrm{~km}^{2}$, fewer than five locations known and an ongoing decline in extent and quality of habitat, this species is considered to be Endangered - EN B1ab(iii).

NOTES. Although the original type material of Barleria newtonii is believed to have been destroyed, the extant specimens cited clearly match the description in the protologue. The neotype selected here was collected from close to the original type locality and is excellent flowering material.

Barleria newtonii is here resurrected as a good species. Clarke (1899) considered it to be conspecific with B. calophylla Lindau, today known from South Sudan and the Central African Republic. The two species do look quite similar on a superficial level but there are numerous differences. Barleria calophylla has (1) a pale pink or rose-pink corolla lacking any spots on the lobes, with a much less strongly offset abaxial lobe and with short glandular hairs externally at least on the lateral lobes, the tube often also with coarser eglandular hairs; (2) considerably longer bracteoles that vary from being subulate to elliptic and leafy; (3) outer calyx lobes with a rounded, not cordate, base, and (4) the leaves and bracts typically dry blackish-green whereas in $B$. newtonii they dry green. There is no doubt that they are separate species. Barleria calophylla is noted to have 4-seeded capsules (I.D., pers. obs.); the capsules of B. newtonii are not known but based on similarity to the following group of species (spp. 34-39) they are considered likely to be 2-seeded.

34. Barleria imatensis I.Darbysh. sp. nov. Type: Angola, Tchivinguiro, na quinta de Escola de Regentes Agrícolas, fl. 18 Jan. 1962, Barbosa E Moreno 10002 (holotype LUBA!; isotypes K! [K001009549], LISC! [LISC043649], PRE!).

http://www.ipni.org/urn:lsid:ipni.org:names:77214827-1

Barleria polyneura sensu Brummitt \& Seyani (1978: 726), pro parte, non S.Moore (1880: 266).

Suffruticose herb, many branched from a woody rootstock, stems prostrate or procumbent, $10-30 \mathrm{~cm}$ long, drying red-brown, with pale antrorse or spreading hairs either sparse and restricted to two opposite lines or more widespread on young stems. Leaf buds densely pubescent with cream-coloured hairs but soon glabrescent. Leaves subsessile, blade somewhat coriaceous, ovate or ovate-elliptic, $2.7-3.8 \times 1.4-2.3 \mathrm{~cm}$ (l:w ratio $1.4-2.3$ : 1 ), base rounded, subcordate or obtuse, margin entire, apex acute or obtuse, apiculate, surfaces glabrous; lateral veins $4-7$ pairs, these and reticulate tertiary venation prominent beneath. Inflorescences of single-flowered cymes in upper axils; bracts foliaceous; cymes subsessile or peduncle to $4.5 \mathrm{~mm}$ long; bracteoles lanceolate, linear-lanceolate or elliptic to broadly so, $4.7-13.5 \times 1-10 \mathrm{~mm}$, conduplicate and often enveloping calyx base, apex acute to rounded, surfaces glabrous; pedicels to $1.2 \mathrm{~mm}$ long, glabrous. Calyx drying green or brown-green, accrescent; anterior lobe broadly ovate, $17-22 \times 15$ $-16.5 \mathrm{~mm}$ in flower, up to $30 \times 26.5 \mathrm{~mm}$ in fruit, base cordate or shallowly so, margin entire, apex shallowly notched or emarginate for up to $1.8 \mathrm{~mm}$, surfaces glabrous except for few strigulose hairs at apex, palmate venation prominent; posterior lobe as anterior lobe but 21 - $24.5 \mathrm{~mm}$ long in flower, up to $32.5 \mathrm{~mm}$ long in fruit, apex obtuse or acute, apiculate, margin involute; lateral lobes pale, linear-lanceolate, c. $6 \mathrm{~mm}$ long in flower, up to $11.5 \mathrm{~mm}$ long in fruit, glabrous. Corolla 30 - $33 \mathrm{~mm}$ long, lilac, pubescent towards apex of lateral lobes externally; tube 15 $18 \mathrm{~mm}$ long, cylindrical, c. $2.5 \mathrm{~mm}$ in diam. below insertion point of stamens, barely expanded above, mouth 3-4 $\mathrm{mm}$ in diam.; limb subregular, abaxial lobe slightly offset from remaining lobes, obovate, 15.5 - $16.5 \times 8.5 \mathrm{~mm}$, apex slightly emarginate; lateral lobes obovate, $14-15 \times 8.5-9.5 \mathrm{~mm}$, apices rounded or slightly emarginate; adaxial lobes as lateral lobes but $4.5-5 \mathrm{~mm}$ wide. Stamens inserted in proximal half of corolla tube; filaments 11 - 12 mm long; anthers 2.7 $2.8 \mathrm{~mm}$ long, held at corolla mouth; lateral staminodes minute, $\pm 0.5 \mathrm{~mm}$ long. Pistil glabrous; 


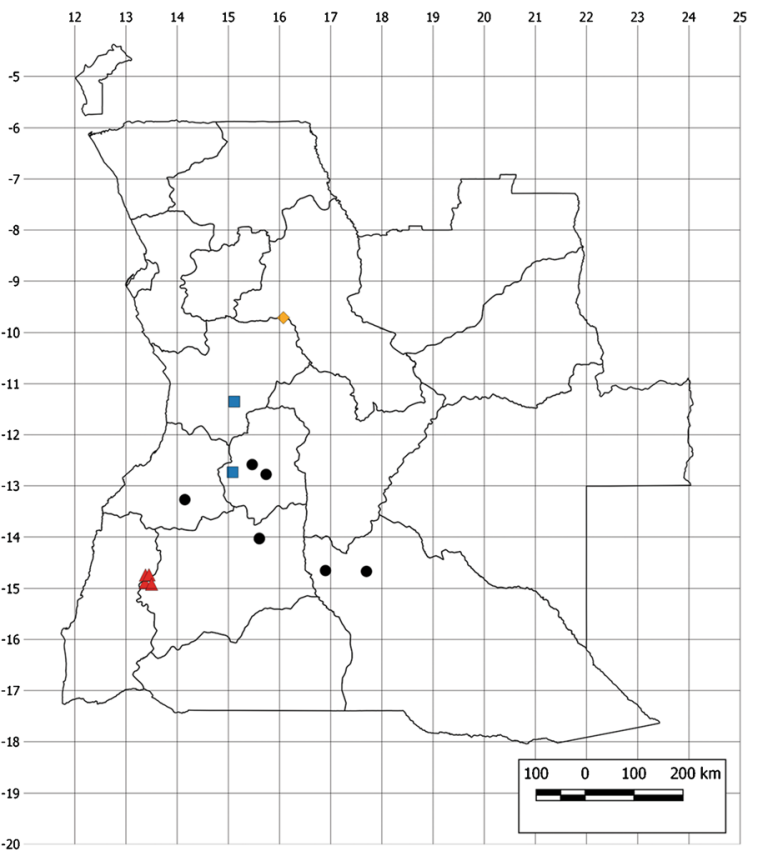

Map 1. Distribution of Barleria newtonii (red triangles), B. pabularis (black circles), B. welwitschii (yellow diamond) and $B$. louiseana (blue squares).

stigma linear, 2.2 - $2.4 \mathrm{~mm}$ long, curved. Capsule 2seeded, $\pm 20 \mathrm{~mm}$ long including beak $6.5 \mathrm{~mm}$, glabrous; seeds $9.5 \times 8 \mathrm{~mm}$. Fig. 2 .

RECOGNITION. This species resembles Barleria polyneura in being a largely glabrous trailing suffruticose herb with ovate leaves and broadly ovate calyces. However, it differs from B. polyneura in having smaller leaves 2.7 $-3.8 \mathrm{~cm}$ long (vs $4.3-7 \mathrm{~cm}$ long), the corolla being lilac (vs white or cream-coloured sometimes with a violet throat), the lobes being narrower, the adaxial lobes being only $4.5-5 \mathrm{~mm}$ wide (vs $9.5-11.5 \mathrm{~mm}$ wide), and equal in length to or slightly shorter than the tube (vs lobes slightly longer than the tube), the lateral lobes being pubescent (vs all lobes glabrous) and in having smaller anthers $2.7-2.8 \mathrm{~mm}$ long (vs $3.4-3.8 \mathrm{~mm}$ long).

DISTRIBUTION. Endemic to Southwest Angola (Cunene and Huíla Provs.); Map 2.

ADDITIONAL COLLECTIONS STUDIED. ANGOLA. Tchivinguiro, próximo da Escola de Regentes Agrícolas, fl. 5 Jan. 1962, Barbosa E Moreno 9803 (LUBA*); Cahama, fr. 18 May 1909, Pearson 2482 (K!). HABITAT \& ECOLOGY. Barleria imatensis is recorded from secondary dry "forest" (more likely to be a form of xeric woodland) on limestone outcrops and in dry places with Bauhinia sp.; it occurs at c. $1200-1550 \mathrm{~m}$ elevation.

CONSERVATION STATUS. This species is known only from two historic locations in southwest Angola. Satellite imagery available on Google Earth shows that at both of these sites there are areas of land extensively transformed due to agricultural activity. However, in the vicinity of the Instituto Médio Agrario do Tchivinguiro there are still areas of intact natural vegetation where this species may well be found. Further, the Cunene part of its range is underexplored botanically, and areas away from the main transport routes appear to have some intact vegetation still in place. This species may also be protected from some of the most severe human impacts by its preference for rock outcrops, although this requires confirmation. With more information needed on the full range, abundance and threats to this species, it is currently assessed as Data Deficient - DD, but it may well prove to be threatened once more complete data are available.

ETYMOLOGY. This species is named after the Instituto Médio Agrario do Tchivinguiro (IMAT, formerly the Escola de Regentes Agrícolas do Tchivinguiro), the type locality for this species. It is hoped that this species can be rediscovered and protected within the grounds of this Institute.

NOTES. This species has previously been included within Barleria polyneura (Brummitt \& Seyani 1978; Darbyshire 2010) but, although they are clearly closely allied, they differ in quite a number of characters as listed in the Recognition section. More material is desirable to confirm some of the differences e.g. in corolla form, but we have little doubt that they are different species.

NOTE ON SPECIES 35 - 38: THE BARLERIA POLYNEURAVIOLASCENS COMPLEX. Barleria polyneura, B. benguellensis and $B$. violascens together form a species complex and they could ultimately prove to be variants of a single species, or perhaps two species with $B$. polyneura maintained as separate from $B$. violascens (including $B$. benguellensis). They all share the combination of trailing, procumbent or weak decumbent branches, red-brown stems, largely glabrous foliage and broad, ovate or ovate-elliptic, largely glabrous calyces. However, based on the material seem to date, they are easily separated vegetatively and so are maintained as distinct here, with two varieties recognised within B. violascens.

35. Barleria polyneura S.Moore (1880: 266); Clarke (1899: 157); Hiern (1900: 815); Moore (1930: 134); Brummitt \& Seyani (1978: 726), pro parte — see note; Klopper et al. (2006: 4); Makholela (2008: 22). Type: Angola, "inter lacum Ivantala et Quilongues", fl. \& fr. 29 Feb. 1860, Welwitsch 5029 (lectotype BM! [BM000914332], selected here; isolectotypes K! [K000394518], LISU! [LISU223396, LISU223397], P* [P00434418]).

Suffruticose herb, several branched from a woody rootstock, stems prostrate, procumbent or weakly 


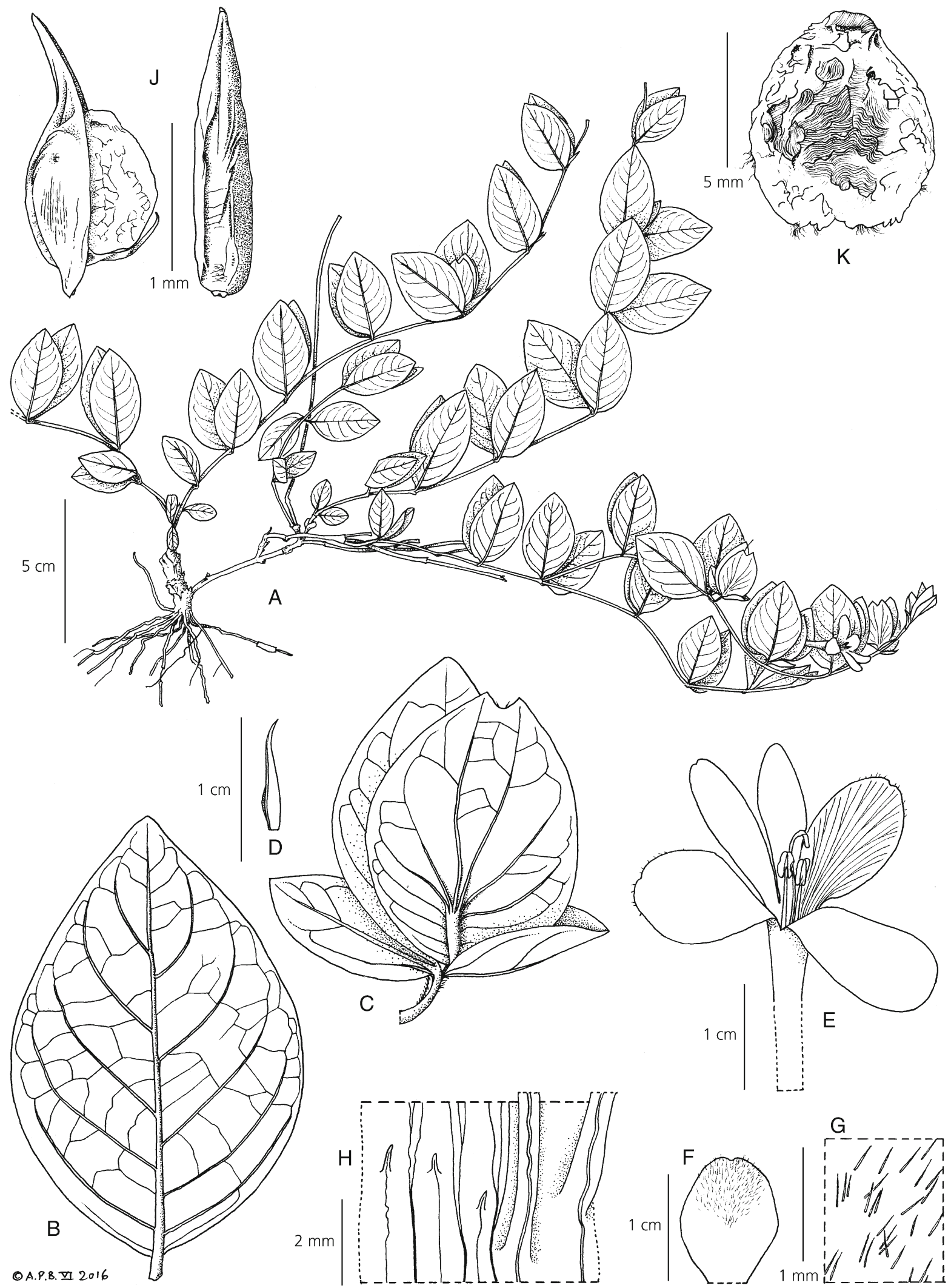

Fig. 2. Barleria imatensis. A habit; B leaf, abaxial surface; C calyx and subtending bracteoles; D lateral calyx lobe; E corolla, with lobes spread for display; $\mathrm{F}$ external surface of distal portion of lateral corolla lobe showing indumentum; $\mathrm{G}$ detail of hairs on lateral corolla lobes; $\mathrm{H}$ detail of staminodes and staminal filament bases; J valve of capsule, (left) lateral view with seed in situ, (right) dorsal view; K seed. A - H from Barbosa \& Moreno 10002, J \& K from Pearson 2482. DRAWN BY ANDREW BROWN. 
ascending, 10 - $30 \mathrm{~cm}$ long, drying dark red-brown, with pale antrorse or spreading hairs sparse and restricted to two opposite lines, later glabrescent. Leaf buds densely pubescent with cream-coloured hairs but soon glabrescent. Leaves subsessile, blade somewhat coriaceous, glaucous-green but often drying browngreen, largest leaves ovate, $4.3-7 \times 2.6-3.7 \mathrm{~cm}(\mathrm{l}: \mathrm{w}$ ratio $1.3-2.1: 1$ ), base rounded, subcordate or obtuse, margin entire, apex acute- or obtuse-apiculate, surfaces glabrous; lateral veins $4-7$ pairs, these and reticulate tertiary venation prominent beneath. Inflorescences of single-flowered cymes in upper axils; bracts foliaceous but those towards stem apices reduced, often elliptic or obovate with base attenuate, typically $16-37 \times 7.5-21 \mathrm{~mm}$; cymes subsessile or peduncles to $6 \mathrm{~mm}$ long; bracteoles erect or ascending, either linear or oblanceolate, $4-22 \times 0.5-9 \mathrm{~mm}, \pm$ conduplicate, apex acute or rounded, surfaces glabrous; pedicels $2.5-7 \mathrm{~mm}$ long, appressed-pubescent or glabrous. Calyx often drying dark green or purplishbrown, somewhat accrescent; anterior lobe broadly ovate, $18.5-25.5 \times 13.5-19 \mathrm{~mm}$ in flower, up to $28 \times$ $21.5 \mathrm{~mm}$ in young fruit, base cordate, margin entire, apex shallowly notched or emarginate for up to $1 \mathrm{~mm}$, surface glabrous, palmate venation prominent; posterior lobe as anterior lobe but $19-28.5 \mathrm{~mm}$ long in flower, up to $32 \mathrm{~mm}$ long in fruit, apex obtuse or acute; lateral lobes linear-lanceolate, 9 - 14 mm long, often curved outwards, glabrous. Corolla $35-43 \mathrm{~mm}$ long, white or cream, sometimes with violet throat, glabrous externally; tube 13.5 - $18.5 \mathrm{~mm}$ long, cylindrical below attachment point of stamens where $3-3.5 \mathrm{~mm}$ in diam., narrowly funnel-shaped above, mouth 5 $5.5 \mathrm{~mm}$ in diam.; limb subregular, abaxial lobe slightly offset from remaining lobes, obovate-elliptic or -orbicular, $17.5-21.5 \times 13-15.5 \mathrm{~mm}$, apex rounded or slightly emarginate; lateral lobes obovate or elliptic, $20.5-21.5 \times$ $13-14.5 \mathrm{~mm}$; adaxial lobes as lateral lobes but $17-21 \times$ $9.5-11.5 \mathrm{~mm}$. Stamens inserted c. $5 \mathrm{~mm}$ from base of corolla tube; filaments $10.5-14.5 \mathrm{~mm}$ long; anthers $3.4-$ $3.8 \mathrm{~mm}$ long, held at corolla mouth; lateral staminodes minute, $\pm 0.8 \mathrm{~mm}$ long. Pistil glabrous; stigma linear, 2.2 - $2.7 \mathrm{~mm}$ long, curved. Capsule only seen in immature state, 2-seeded, glabrous. Fig. 3A \& B.

DISTRIBUtION. Endemic to South Angola (Cunene and Huíla Provs.); Map 2.

ADDITIONAL COLLECTIONS STUDIED. ANGOLA. Between the Serra de Ferreira de Amaral and R. Cusaba, fl. 9 April 1907, Gossweiler 2889 (BM!); Huíla, ao km 58 da estrada Sá da Bandeira [Lubango] - Vila Paiva Couceiro [Quipungo], fl. 9 Jan. 1973, Couto 288 (LUBA!); ao km 68 da estrada Sá da Bandeira [Lubango] - Paiva Couceiro [Quipungo], fl. 9 Jan. 1973, Rey E Lourenço 174 (LUBA!); Cunene, Cuvelai, ao km 5 do trajecto Cuvelai - Chamutete, fl. 9 Feb. 1973, Menezes et al. 4394 (LUBA!); Cacula, near Catanha-Mbandi, fl. 19 Jan. 2017,
F. M. P. Gonçalves sight record (photo.!); (?) Quialalla landa, Quipung. [?Quipungo], fl. Jan., without year, Unknown collector s.n. ( $\mathrm{P}^{*}$ [P03605722]).

HABITAT \& ECOLOGY. From the very limited habitat information available, this species appears to favour open woodland including among rocky areas, at c. 1250 - 1750 m elevation.

CONSERVATION STATUS. This species is currently known from six scattered locations in southwest Angola, with an EOO of $21,181 \mathrm{~km}^{2}$. The western portion of this species' range, between Lubango and Quipungo in Huíla Province, has been particularly heavily impacted by human activities (Mendelsohn 2019), including agricultural expansion, increased frequency of fire, fuelwood extraction, charcoal production and urban development (see Chisingui et al. 2018). This species' apparent preference for rocky areas may protect it from some of these pressures but this requires confirmation. Although not known to occur in any protected areas, the southwestern-most site at Cuvelai is close to the Mupa National Park, and the northern portion of the Bicuar National Park also lies within this species' EOO. If found there, these extensive protected areas may offer some protection for this species. Recent studies of woody plant and habitat diversity and structure in Bicuar National Park have noted that this extensive site is still relatively well preserved with extensive intact dry miombo woodland assemblages, despite significant past pressures including selective logging of species and farming activity (da Silva et al. 2020; Godlee et al. 2020). That said, the reserve was reduced from $7,900 \mathrm{~km}^{2}$ to $6,754 \mathrm{~km}^{2}$ due to conversion of natural habitat to commercial and subsistence agricultural land in the west and north (Mendelsohn \& Mendelsohn 2018) and there are some ongoing pressures on the park's habitats that need to be better understood and managed (da Silva et al. 2020). The national parks of Angola in general remain highly under-resourced, often without effective management and some, including Mupa, are threatened (Mendelsohn \& Mendelsohn 2018; Huntley et al. 2019b). Based on current evidence, this species is assessed as Near Threatened - NT B1ab(iii) as fewer than 10 locations are known and there are clear threats, but the EOO falls just outside the threshold for Vulnerable under criterion B1.

NOTES. Barleria polyneura is easily separated from $B$. benguellensis and B. violascens by the broadly ovate mature leaves with rounded, obtuse or subcordate bases (cuneate or attenuate in the other two species) and by the broader calyces with a more markedly cordate base, the apex of the posterior lobe usually being obtuse.

Brummitt \& Seyani (1978) assigned several collections of a Barleria species from Malawi to B. polyneura, stating that the only difference between the highly disjunct populations was the cuneate leaf base in the 


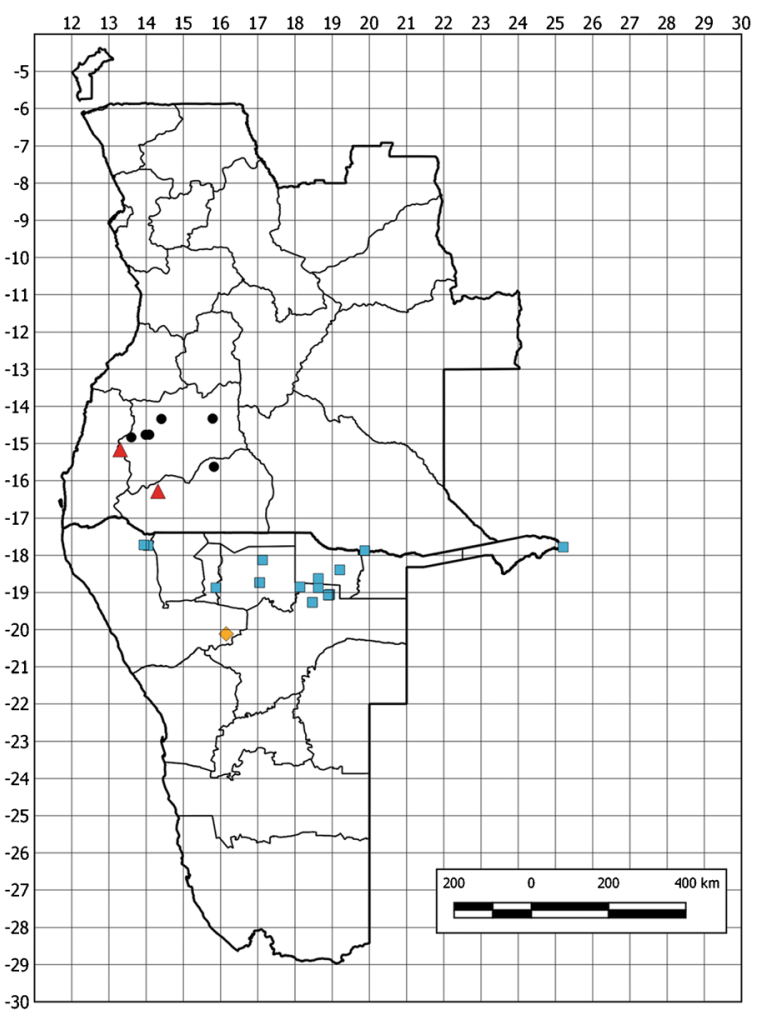

Map 2. Distribution of Barleria imatensis (red triangles), B. polyneura (black circles), B. matopensis (blue squares) and $B$. violacea (yellow diamond).

Malawi material, this being rounded in Angolan specimens. The Malawi plants have since been reidentified as $B$. calophylloides Lindau subsp. pilosa I.Darbysh. (Darbyshire 2010: 396; 2015: 97), with several notable differences to $B$. polyneura, particularly the much larger corolla $50-60 \mathrm{~mm}$ long with tube 25 - $33 \mathrm{~mm}$ long. This close relationship to B. calophylloides sensu stricto, from Tanzania and Zambia, has recently been confirmed by RADseq phylogenetic analyses (Comito 2019). Barleria polyneura has not yet been sequenced but the closely allied $B$. violascens is placed as sister to $B$. calophylloides with strong support.

36. Barleria benguellensis S.Moore (1911: 305); Moore (1930: 135); Klopper et al. (2006: 3); Makholela (2008: 21). Type: Angola, Benguela, Anha, fl. March 1907, Gossweiler 3621 (holotype BM! [BM000931103]; isotype K! [K000430940]).

Suffruticose herb, many-branched from a perennial rootstock (not seen), stems trailing or decumbent, to 30 - $40 \mathrm{~cm}$ long, drying dark red-brown, with two opposite lines of pale \pm antrorse or spreading hairs, later glabrescent. Leaves subsessile, blade somewhat coriaceous, glaucous-green but can dry brown-green, ovate or ovate-elliptic when mature, $6.5-8.7 \times 2.2-$
$3.5 \mathrm{~cm}$ (l:w ratio $2.1-3: 1)$, base cuneate or attenuate, margin entire, apex acute, apiculate, surfaces glabrous or with few strigulose hairs along margin towards leaf base; lateral veins $7-8$ pairs, these and reticulate tertiary venation \pm prominent beneath; young leaves narrowly oblong-elliptic and with apex sometimes more rounded. Inflorescences of singleflowered cymes aggregated into congested terminal spikes $4.5-6 \mathrm{~cm}$ long and also with solitary flowers in uppermost leaf axils; bracts in the spike foliaceous but much reduced, ovate-elliptic, $20-29 \times 5$ - $11 \mathrm{~mm}$, can be pale yellowish-green in dry state; cymes subsessile or peduncle to $3 \mathrm{~mm}$ long; bracteoles held erect or \pm ascending, linearlanceolate or -oblanceolate, $5-18 \times 0.7-3 \mathrm{~mm}$, conduplicate, margin pale-strigulose or glabrous, entire or with minute teeth formed by swollen hair bases; pedicels 2-4 mm long, pale-strigulose. Calyx yellowish-green or brown in dry state; anterior lobe ovate, $17.5-27 \times 14-18 \mathrm{~mm}$, base rounded or subcordate, margin entire, apex notched with two triangular lobes $1-3.5 \mathrm{~mm}$ long, surfaces glabrous except for pale-strigulose margin, with \pm prominent palmate venation; posterior lobe as anterior lobe but 22 - $31 \mathrm{~mm}$ long, apex acute or somewhat attenuate and apiculate, margin often involute, midrib sometimes with few multicellular crisped hairs towards base; lateral lobes lanceolate-attenuate, 12 - $13 \mathrm{~mm}$ long. Corolla [38 - 41] $52 \mathrm{~mm}$ long, white with purple throat or pale violet, glabrous externally; tube [17.5] $20 \mathrm{~mm}$ long, cylindrical below insertion point of stamens where $3-$ $4 \mathrm{~mm}$ in diam., funnel-shaped above, mouth [7] 9 $10 \mathrm{~mm}$ in diam.; limb in weak " $4+1$ " configuration, abaxial lobe offset by c. $4 \mathrm{~mm}$, this and lateral lobes oblong-elliptic or somewhat obovate to broadly so, [2324] $25 \times 16$ [18] mm, apices obtuse to rounded; adaxial lobes fused for a further c. $3-5 \mathrm{~mm}$, oblong-elliptic or elliptic, [22.5] $26-26.5 \times 12.5-14 \mathrm{~mm}$. Stamens inserted [6.5] $8.5 \mathrm{~mm}$ from base of corolla tube; filaments [11 11.5] 19 - 21 mm long; anthers [3.5] 4.7 - $5.2 \mathrm{~mm}$ long; lateral staminodes barely developed, $0.8-1.3 \mathrm{~mm}$ long. Pistilglabrous; stigma linear, $1.8-3 \mathrm{~mm}$ long. Capsule not seen.

DISTRIBUTION. Endemic to Southwest Angola (Benguela and Huíla Provs.); Map 3.

ADDITIONAL COLLECTION STUDIED. ANGOLA. Huíla, Ganguelas, Cassinga, ao km 1 do trajecto Chamutete - Cassinga, fl. 14 Feb. 1973, Menezes et al. 4618 (LUBA!) - see note.

HABITAT \& ECOLOGY. The type collection was recorded from amongst short grass in open thickets and Julbernardia ("mumua") woodland; c. 1100 - 1300 m elevation.

CONSERVATION STATUS. This species is only known from two localities, both of which are from areas 

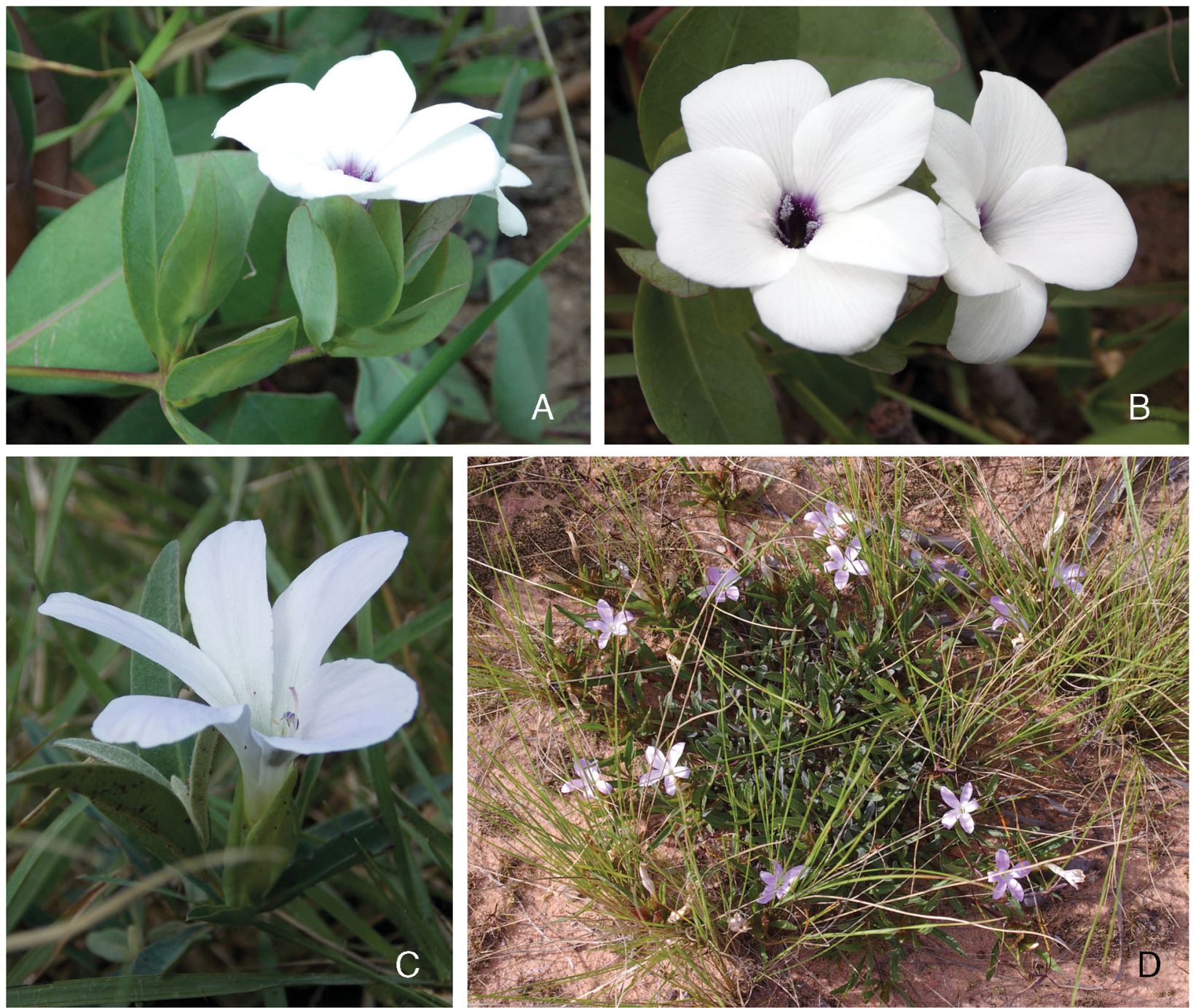

Fig. 3. A, B Barleria polyneura: A habit, flowering branch; B flowers. C Barleria violascens var. violascens, flower. D Barleria violascens var. humpatana, habit (collected as Crawford FC373). PHOTOS: A - C F. M. P. GONÇALVES, D F. M. CHASE (ALL IMAGES ANGOLA).

now heavily transformed by human activities including agriculture and settlement, as evidenced from Google Earth imagery. However, with only limited habitat information available and with some uncertainty over the taxonomy of this species (see Notes), it must currently be assessed as Data Deficient - DD.

NOTES. This species is most likely to be confused with Barleria violascens, the main differences being that $B$. benguellensis has considerably larger and broader leaves with l:w ratio $2.1-3: 1$ (vs $3-10.5$ : 1 ), and a more contracted compound inflorescence. In addition, the type specimen has a more markedly funnelshaped corolla tube, c. $9-10 \mathrm{~mm}$ diam. at the mouth (vs campanulate to narrowly funnel-shaped, 3.5 $7 \mathrm{~mm}$ diam. at the mouth in B. violascens) and larger anthers (4.7 - $5.2 \mathrm{~mm}$ long, vs $3-4 \mathrm{~mm}$ long). However, a second collection that closely matches the type specimen vegetatively (Меnezes et al. 4618) has smaller, less markedly funnel-shaped corollas with shorter, broader lobes and with smaller stamens, all of which are similar to $B$. violascens - the floral measurements for this second collection are placed in square brackets in the description here. The type locality is quite distant from the locality of this second collection and it is possible that they represent different taxa that are vegetatively similar.

37. Barleria violascens S.Moore (1880: 265); Hiern (1900: 815); Moore (1930: 135); Klopper et al. (2006: 5); Makholela (2008: 22). Type: Angola, Distr. Huíla, "gegen Eme", fl. April 1860, Welwitsch 5016 (lectotype BM! [BM001124098], selected here; isolectotypes C* [C10000005], K! [K000394517], LISU! [LISU223398], P* [P03591480]). Additional syntypes: Distr. Huíla, "gegen Eme", fl. April 1860, Welwitsch 5015 (BM! [BM000931115]); Huíla, "in dumetis editis de 5000 
ad 5300 ped. in Morro de Lopolo”, fl. 17 Feb. 1860, Welwitsch 5028 (BM! [BM000931116], LISU! [LISU223399]).

Suffruticose herb, few - many branched from a woody rootstock, stems prostrate or procumbent, $5-30 \mathrm{~cm}$ long, usually drying dark red-brown, with pale \pm antrorse hairs restricted to or most dense on two opposite sides. Leaf buds often densely pubescent with cream-coloured hairs. Leaves sessile or petiole to $7 \mathrm{~mm}$ long; blade somewhat coriaceous, glaucous-green but often drying green-brown, narrowly elliptic, lanceolate or linear-lanceolate, 2.8 - 8.6 $\times 0.4-2 \mathrm{~cm}$ (l:w ratio $3-10.5$ : 1 ), base cuneate or attenuate, margin entire or shallowly undulate, apex acute-apiculate, surfaces glabrous or midrib strigulose beneath, young leaves sometimes with dense fine whitewooly hairs but these \pm soon caducous; lateral veins $5-7$ pairs. Inflorescences of single-flowered cymes in upper axils, sometimes aggregated into loose leafy terminal spikes to $6 \mathrm{~cm}$ long; bracts foliaceous but those towards the stem apices much reduced, then typically oblong-elliptic to subulate, $23-56 \times 3-10 \mathrm{~mm}$; cymes subsessile or peduncles to $6(-11.5) \mathrm{mm}$ long; bracteoles ascending or spreading, narrowly oblanceolate or subulate, $7-30 \times 1$ $4.5 \mathrm{~mm}$, often conduplicate, glabrous or margin and midrib with few pale antrorse hairs, midrib sometimes also with spreading multicellular hairs; pedicels absent or to $4.5 \mathrm{~mm}$ long, appressed-pubescent. Calyx green with purplish veins or purple throughout, often drying brown, accrescent; anterior lobe ovate or ovate-elliptic, 15.5 - 23.5 $\times 10-17 \mathrm{~mm}$ in flower, up to $32.5 \times 21 \mathrm{~mm}$ in fruit, base rounded or shallowly cordate, margin entire, often involute, apex shallowly notched to more deeply bifid for 0.3-6 mm, surfaces glabrous or margin and lower portion of midrib with pale antrorse or appressed hairs, rarely midrib with few spreading multicellular hairs; posterior lobe as anterior lobe but $17-27 \mathrm{~mm}$ long in flower, up to $36.5 \times 24 \mathrm{~mm}$ in fruit, apex acute or attenuate and apiculate; lateral lobes linear-lanceolate, 7 - $9 \mathrm{~mm}$ long, with sessile glands on surface. Corolla 32 - $53 \mathrm{~mm}$ long, purple, blue-purple or lilac throughout or with lobes or whole flower white, glabrous externally; tube $16-25.5 \mathrm{~mm}$ long, cylindrical below insertion point of stamens where $2.5-4 \mathrm{~mm}$ in diam., narrowly campanulate above, mouth 3.5 - $7 \mathrm{~mm}$ diam.; limb subregular, abaxial lobe obovateorbicular to oblong-obovate or -elliptic, $15-23.5 \times 7-16.5$ $\mathrm{mm}$, apex rounded or emarginate; lateral lobes obovate to oblong-elliptic, $15-25.5 \times 6-15 \mathrm{~mm}$, apices obtuse to rounded; adaxial lobes as lateral lobes but $14.5-23 \times 4.5-$ $12.5 \mathrm{~mm}$. Stamens inserted $5.5-6.5 \mathrm{~mm}$ from base of corolla tube; filaments 11.5 - $16 \mathrm{~mm}$ long; anthers 3 $4 \mathrm{~mm}$ long, held at corolla mouth; lateral staminodes sometimes barely developed, $0.5-2.5 \mathrm{~mm}$ long. Pistil glabrous; stigma linear, 1.9 - $2.7 \mathrm{~mm}$ long, curved. Capsule 2-seeded, 17.5 - $23 \mathrm{~mm}$ long including beak $6.5-9 \mathrm{~mm}$ long, glabrous; seeds $8.3-9.5 \times 7.2-7.6 \mathrm{~mm}$. Fig. 3C \& D.

\section{7a. Barleria violascens S.Moore var. violascens}

Leaves narrowly elliptic or lanceolate, $8-20 \mathrm{~mm}$ wide, l:w ratio $3-4.7$ : 1 . Fig. $3 \mathrm{C}$.

DISTRIBUTION. Endemic to Southwest Angola (Cunene, Cuando Cubango, Huíla and Namibe Provs.); Map 3.

ADDITIONAL COLLECTIONS STUDIED. ANGOLA. Kutchi [Cuchi] R., fr. May 1906, Gossweiler 3124 (BM!); Gimbundo Jamaiambe, fr. May 1906, Gossweiler 3813 (BM!); between the fortification on the R. Cubango: Catoco - Ganguellas, fl. 10 Jan. 1907, Gossweiler 2506 (BM!, LISC!); Cubango near Fort Princeza Amelia, fl. Jan. 1902, Gossweiler 2941 (BM!, K!); Missão Catolica de Huíla, fl. 28 Jan. 1956, Mendes 1450 (K!, LISC!); Ganguelas, andados $33 \mathrm{~km}$ de Vila Artur de Paiva [Kuvango] para Cassinga, fl. 15 Jan. 1960, Mendes 2118 (K!, LISC!); Menongue, andados $50 \mathrm{~km}$ de Caiundo para Vila Serpa Pinto [Menongue], fl. 4 Feb. 1960, Mendes 2344 (LUBA!); Sá da Bandeira [Lubango], Vila Arriaga [Bibala] no Garganta, fl. \& fr. 16 March 1963, Loureiro 19 (LUBA!); Chibia, near Gangelas Dam, fl. 15 April 2017, F. M. P. Gonçalves sight record (photo.!).

HABITAT \& ECOLOGY. Var. violascens is recorded from open and degraded woodland, Julbernardia ("mumua") woodland and thicket including on shallow soils in areas of exposed laterite, and open areas with rocky outcrops; it occurs at c. $1150-1750 \mathrm{~m}$ elevation.

CONSERVATION STATUS. This subspecies is restricted to southern Angola, with an EOO of 40,211 km² based on known occurrence data. This is well in excess of the upper limit for a threatened category under IUCN Criterion B1. The western and northern parts of its range have a high human population and extensive losses of natural vegetation cover due to settlement, agriculture and firewood extraction, and this loss is ongoing (see Mendelsohn 2019, figs. 8.1 and 8.8). However, this subspecies appears to be tolerant of some disturbance, and occupies a variety of habitats including areas that are likely to be protected from the most severe human disturbance, such as rock outcrops. Therefore, although the population may well be in decline, it is provisionally assessed as of Least Concern - LC.

NOTES. Spencer Moore wrote on the BM sheet of Gossweiler 3124 and 3813 "this is a new species but not described in the absence of a satisfactory corolla. It comes close to $B$. polyneura and $B$. violascens, having much the outer calyx segments of the former and leaves of the latter species". However, it is our view that these two specimens (and also Gouveia 1173 which is a close match) are fruiting material of Barleria violascens; the calyx is accrescent which accounts for the difference to the flowering material previously seen by Moore, but it still has the acute or attenuate apices to the calyx lobes and the slender leaves and long slender bracteoles clearly match B. violascens. 


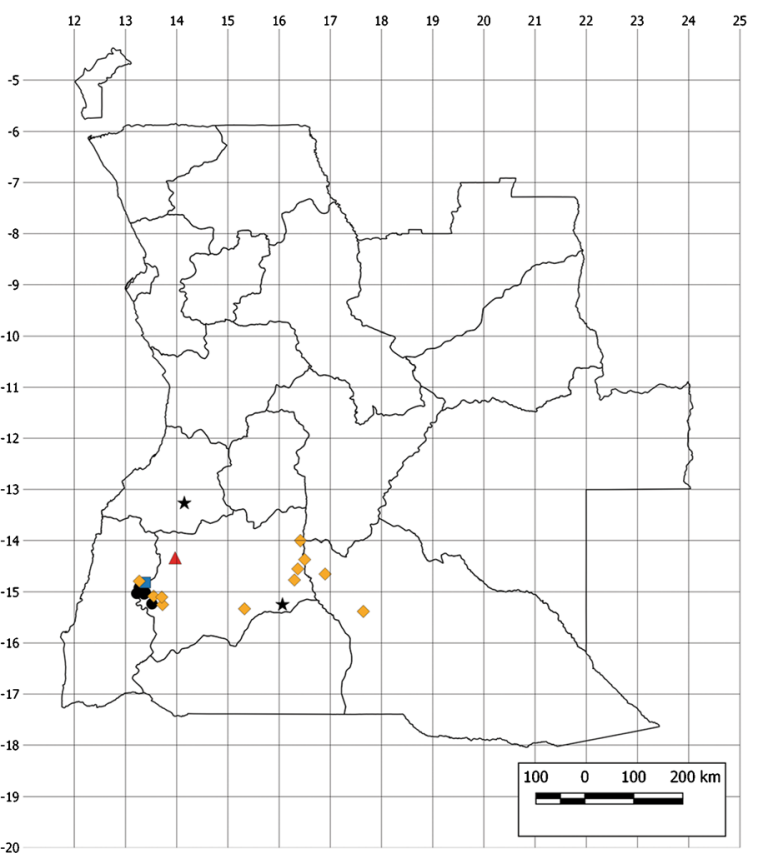

Map 3. Distribution of Barleria benguellensis (black stars), $B$. violascens var. violascens (yellow diamonds), $B$. violascens var. humpatana (black circles) , B. violascens s.I. (blue square) and B. sp. (= Boss s.n.) (red triangle).

37b. Barleria violascens S.Moore var. humpatana I.Darbysh. var. nov. Type: Angola, Humpata, prox. do campo da Aviação, fl. 30 Jan. 1956, Torre 8560 (holotype LUBA!).

http://www.ipni.org/urn:lsid:ipni.org:names:77215730-1

Leaves linear-lanceolate or very narrowly oblong, 4 $9 \mathrm{~mm}$ wide, l:w ratio $(4.7-) 6-10.5$ : 1 . Fig. 3D.

RECOGNITION. Var. humpatana is separated from var. violascens by its narrower, linear-lanceolate or very narrowly oblong leaves which are typically over six times longer than wide (vs leaves narrowly elliptic or lanceolate, typically less than five times longer than wide).

DISTRIBUTION. Endemic to the Lubango Highlands in Southwest Angola (Huíla Prov.); Map 3.

ADDITIONAL COLLECTIONS STUDIED. ANGOLA. Humpata, na margem do Rio Nene, fl. 14 Feb. 1957, Teixeira 2029 (LUBA!, PRE!); Humpata, Estação Agricola da Humpata, fl. 20 Feb. 1957, Teixeira 2087 (PRE!); Huíla, Jau, fr. 11 March 1966, Correia 3519 (LUBA!); c. 15 km NW of Humpata, Estação Zootecnica, fl. 16 Jan. 2009, Bester 9064 (LUBA!, PRE!); Humpata, old veterinary Zootecnica, fl. 16 Jan. 2009, Crawford FC373 (K!, PRE!).

HABITAT \& ECOLOGY. Var. humpatana grows in full sun in upland grassland with rocky outcrops and in fireprone wooded grassland; it is also recorded from open secondary ruderal communities; 1700 - $2250 \mathrm{~m}$ elevation.
CONSERVATION STATUS. This variety is restricted to the area around and northwest of Humpata in the Lubango highlands, with an EOO of only $162 \mathrm{~km}^{2}$. It was recorded as frequent and abundant by Teixeira (2087) but was found to be uncommon during recent botanical exploration in this area (Crawford FC 373). Much of the natural vegetation of the Humpata area has been transformed by human settlement and intensive agricultural activities. This variety can occur in rocky habitats that are likely to have been spared from the most intense human activities in these highlands, and it is tolerant of some disturbance and can persist in secondary vegetation. Even so, it is highly likely to have experienced population declines due to habitat transformation. With fewer than five locations known, it is therefore assessed as Endangered - EN B1ab(iii)+2ab(iii).

NOTES. This variety is restricted to the Humpata area south to Jau in the western Lubango highlands; var. violascens is usually recorded from lower altitudes, chiefly in the Cubango and Cunene catchments but also occurs in the eastern Lubango highlands and the two may not be entirely allopatric in the Lubango region. Santos $\mathcal{E}$ Henriques 379 from the Miradouro da Tunda Vala, fl. 10 Dec. 1961 (LUBA!) is intermediate between the two varieties. Given that the Humpata taxon is separated only on leaf shape, although this gives it a strikingly different appearance to most specimens of $B$. violascens, it is here treated at the varietal rank. In some specimens of var. humpatana (most notably Crawford FC373), the young leaves have a fine wooly indumentum which is later glabrescent; however, in other material these hairs are more quickly caducous. This character has not been seen in var. violascens although the leaf buds there are densely hairy.

\section{Barleria sp. (= Boss s.n.).}

Herb, basal parts not seen, stems red-brown at least when young, glabrous except for minute hairs on two opposite sides when young. Leaves sessile or petiole to $5 \mathrm{~mm}$ long; blade drying brown, narrowly lanceolate, $5.2-7.3 \times 0.8-1 \mathrm{~cm}$ (1:w ratio $6-8: 1)$, base cuneate, margin entire, somewhat revolute, apex acute-apiculate, surfaces glabrous; lateral veins $4-5$ pairs but obscure, midrib prominent beneath. Inflorescences of single-flowered cymes aggregated into a terminal spike $4.5-5.5 \mathrm{~cm}$ long, sometimes with additional singleflowered cymes in upper leaf axils; bracts foliaceous but rapidly reducing up the spike where narrowly oblong-elliptic or -lanceolate, $27-34 \times 7-9 \mathrm{~mm}$, can be caducous in fruit; peduncle of each cyme to $2.5 \mathrm{~mm}$ long in fruit or those of lowermost cymes up to $10.5 \mathrm{~mm}$ long, glabrous; bracteoles ascending, narrowly oblong-elliptic or somewhat oblanceolate, $15-26 \times 3-5.2 \mathrm{~mm}$, conduplicate, glabrous. Calyx ?purplish; anterior and posterior lobes subequal, 
elliptic-rhombic, $21-24 \times 9-10 \mathrm{~mm}$ in fruit, base cuneate or attenuate, margin involute, apex of anterior lobe notched for c. $1 \mathrm{~mm}$ with acute-triangular lobes, posterior lobe acute, surfaces glabrous; lateral lobes linear-lanceolate, 8.5 - $10 \mathrm{~mm}$ long in fruit, glabrous. Corolla not seen. Capsule 2-seeded but with vestigial remains of second seed per locule apparent at slightly tapered base, 23 - $24 \mathrm{~mm}$ long including beak $6.5 \mathrm{~mm}$ long, glabrous; seeds c. $9.5 \times 8 \mathrm{~mm}$.

DISTRIBUtion. Southwest Angola (Huíla Prov.); Map 3. COLLECTION STUDIED. ANGOLA. Lukundu [Lucondo], Tschiwinguru, fr. May 1954, Boss s.n. (M!, WAG!) see note.

HABITAT \& ECOLOGY. No habitat information is recorded on the single known specimen.

CONSERVATION STATUS. In view of the uncertain taxonomic status of this taxon and the lack of habitat information, it is assessed as Data Deficient - DD.

NOTES. The single specimen seen lacks basal parts and flowers. From the fruiting material, it appears to be close to the Barleria polyneura-violascens group, sharing the largely glabrous vegetative parts and calyces, reddish-brown stems and glabrous, 2-seeded capsules. It looks most similar to $B$. violascens, sharing the narrowly lanceolate leaves of that species, and could be a variant of that species but it differs in having elliptic-rhombic outer calyx lobes with a cuneate or attenuate base (vs ovate to ovate-rhombic with a rounded or shallowly cordate base in B. violascens), and a more well-defined and dense terminal inflorescence.

The M and WAG sheets are believed to be derived from the same collection but the label data differ slightly on the two sheets; the WAG sheet has the extra locality "Tschiwinguru" recorded, and the date is given only as "1954/55".

39. Barleria antunesii Lindau (1895b: 116); Clarke (1899: 165); Klopper et al. (2006: 3); Makholela (2008: 21). Type: Angola, Huilla [Huíla], without date, Antunes s.n. (holotype ?B $\dagger$ ) - see note.

Suffruticose herb, branched from a woody base, with a woody tuberous rootstock, stems erect, $10-30 \mathrm{~cm}$ tall, tinged purple when young, pubescent with pale \pm antrorse hairs, most dense on two opposite sides. Leaves sessile or petiole to $2 \mathrm{~mm}$ long; blade glaucousgreen, narrowly oblong-lanceolate, $5.5-7 \times 0.6-$ $1.2 \mathrm{~cm}$ (1:w ratio $5-8.5: 1$ ), base cuneate, margin entire, apex acute-apiculate, margin antrorse-pubescent, midrib with longer antrorse or more spreading hairs beneath; lateral veins $5-7$ pairs but obscure. Inflorescences of few single-flowered cymes crowded in the upper leaf axils; bracts foliaceous but those towards the stem apices somewhat reduced, $25-44 \times$
$3.5-6.5 \mathrm{~mm}$; flowers subsessile; bracteoles ascending, subulate or narrowly oblanceolate, $12-21 \times 1.5-2.2$ $\mathrm{mm}$, conduplicate, antrorse-pubescent. Calyx pale green-brown; anterior lobe ovate-rhombic, 18 - $24 \times$ 11 - $12 \mathrm{~mm}$, base obtuse, margin involute, apex notched for $1.2-3 \mathrm{~mm}$, external surface densely pale antrorse-pubescent; posterior lobe as anterior lobe but somewhat longer, apex \pm attenuate and apiculate; lateral lobes straw-coloured, lanceolate-attenuate, 8.5 $9.5 \mathrm{~mm}$ long, pubescent. Corolla [measurements based on one flower] c. $35 \mathrm{~mm}$ long, white, glabrous externally; tube $15.5 \mathrm{~mm}$ long, cylindrical below insertion point of stamens where $3.5 \mathrm{~mm}$ in diam., narrowly widened above, mouth $6.5 \mathrm{~mm}$ in diam.; limb subregular, abaxial lobe obovate-orbicular, $17.5 \times 15$ $\mathrm{mm}$; lateral lobes obovate, $15 \times 12-14 \mathrm{~mm}$; adaxial lobes obovate, $16 \times 11.5 \mathrm{~mm}$. Stamens inserted $5 \mathrm{~mm}$ from base of corolla tube; filaments $12-13 \mathrm{~mm}$ long; anthers 3.7 - $4.3 \mathrm{~mm}$ long, held above corolla mouth; lateral staminodes minute, $0.4-0.7 \mathrm{~mm}$ long. Pistil glabrous; stigma linear, c. $2 \mathrm{~mm}$ long, curved. Capsule not seen.

DISTRIBUtION. Endemic to Southwest Angola (Huíla Prov.); Map 4.

COLLECTION STUdied. ANGOlA. Huíla, Matéta [?Mutata], fl. 16 Jan. 1956, Teixeira 1813 (PRE!). Additional collection cited by Clarke (1899): Huíla, Capello 19 (n.v.).

HABITAT \& ECOLOGY. The single specimen seen was recorded from on clay soils at c. $1700 \mathrm{~m}$ elevation; no further habitat information is available. It appears to be endemic to the Huíla Plateau.

CONSERVATION STATUS. This species is recorded only from the Huíla area and the exact collecting locality of the extant specimen has not been confirmed. It is clearly scarce, as this part of Angola has been more thoroughly botanised than most parts of Angola. The Huíla Highlands have been heavily denuded of their vegetation with extensive conversion to farmlands and this is likely to have impacted this scarce species. Therefore, it is highly likely to be threatened. However, with almost no habitat information available for this species, it must currently be considered Data Deficient - DD.

NOTES. We have not been able to trace any duplicates of the Antunes type specimen, nor have we traced Capello 19 which is cited under this species by Clarke (1899). The description above is based solely on Teixeira 1813. This specimen broadly agrees with the description of Barleria antunesii in the protologue although there are some differences: Lindau (1895a) recorded the anterior calyx lobe as $25 \times 20 \mathrm{~mm}$ (although Clarke 1899 says nearly $1 \times 3 / 5$ in. [= $25 \times$ $15 \mathrm{~mm}]$ ) and the posterior lobe as $30 \times 21 \mathrm{~mm}$, and he records the corolla as larger, with tube $20 \mathrm{~mm}$ long and lobes $25 \mathrm{~mm}$ long, the abaxial lobe $20 \mathrm{~mm}$ wide, 
lateral lobes $15 \mathrm{~mm}$ wide and adaxial lobes $13 \mathrm{~mm}$ wide. The larger calyces could potentially be accounted for by accrescence at maturity and the variation in corolla size is not unusual in Barleria. Clarke (1899) placed B. antunesii as allied to members of sect. Fissimura and to B. holstii Lindau which is in sect. Barleria but looks similar to species of sect. Fissimura. This placement is clearly wrong, however, since without doubt the protologue description places B. antunesii in sect. Somalia, and Lindau (1895b) suggested that it is allied to $B$. calophylla and relatives. We are reluctant to select Teixeira 1813 as a neotype of Barleria antunesii in view of the slight discrepancies listed above and in case either of the two specimens seen by Clarke come to light.

This species is morphologically similar to Barleria violascens, and particularly to var. humpatana, but it clearly differs in the densely hairy calyces and bracteoles and the more erect habit.

40. Barleria matopensis S.Moore (1907a: 91); Obermeyer (1933: 149); Welman (2003: 94); Klopper et al. (2006: 4); Pickering \& Roe (2009: 13); Darbyshire et al. (2012: 766); Klaassen \& Kwembeya (2013: 129); Darbyshire (2015: 102). Type: Zimbabwe, Matopo Hills, fl. \& fr. Feb. 1903, Eyles 1165 (holotype BM! [BM000931090]; isotype GRA* [GRA0002737-0]).

Barleria albi-pilosa Hainz ex Suess. \& Merxm.

(Suessenguth \& Merxmüller 1955: 67); Meyer (1957: 380; 1968: 10); Balkwill \& Balkwill (1997: figs. 6S \& 12J); Craven (1999: 152); Welman (2003: 93); Klopper et al. (2006: 3). Type: Namibia, Etosha Pan, Onguma, "Gelbholzdüne”, fl. 8 July 1952, H. Walter Eं E. Walter 412 (holotype M! [M0109646]; isotypes $\mathrm{B}^{*}$ [B 10 0154011], PRE, WIND! [WIND000031427]).

Shrub or woody perennial herb, erect, decumbent or scrambling, 10 - $300 \mathrm{~cm}$ tall; stems with fine white antrorse-appressed or tomentellous hairs, often dense when young, sometimes also with numerous short patent glandular hairs, later glabrescent, mature stems first chestnut-brown then later with grey-brown bark. Leaf buds densely cream- to silvery-hairy. Leaves ovate, ovate-elliptic or lanceolate, $2-15 \times 0.8-5.6 \mathrm{~cm}(\mathrm{l}: \mathrm{w}$ ratio $(1.5-) 2-4.5: 1)$, base attenuate often with a wing-like extension decurrent onto the petiole, apex acute to rounded, surfaces at first with numerous fine white antrorse or crisped hairs, later glabrescent except along margin and midrib and main veins beneath; lateral veins $4-6$ pairs; petiole to $10(-26)$ mm long. Inflorescences 1 - 3-flowered cymes, axillary but sometimes crowded towards branch apices, sessile or peduncle to $2.5(-4.5) \mathrm{mm}$ long; bracts foliaceous, reducing in size upwards; bracteoles oblanceolate, spathulate or obovate (-elliptic), $11-28 \times 2-10$ $\mathrm{mm}$, indumentum as young leaves, often also with short glandular hairs along margin or more widespread and/or with long-pilose hairs along proximal margin; flowers sessile. Calyx somewhat accrescent; anterior lobe (oblong-) elliptic or ovate-elliptic, 6 $13.5 \times 2.5-9 \mathrm{~mm}$, base acute or attenuate, apex with two acute lobes (1 -) 2-6 mm long, surface with fine white antrorse or tomentellous hairs throughout or restricted to margin and 2 principal veins, usually also with short glandular hairs at least along margin, venation palmate, prominent in fruit; posterior lobe oblong-elliptic or oblong-lanceolate, $8.5-18.5 \times 3-12$ $\mathrm{mm}$, apex acute to rounded; lateral lobes lanceolate, 4 - 7.5 (- 9) mm long. Corolla 27 - 43 mm long, blue, mauve or purple with paler throat, or white throughout, pubescent especially on lateral lobes externally with mixed glandular and eglandular hairs; tube $9.5-$ 17 mm long, cylindrical towards base, campanulate towards mouth; limb in " $4+1$ " configuration; abaxial lobe offset by $3.5-8(-10.5) \mathrm{mm}$, obovate, $14-23 \times 8$ - $16 \mathrm{~mm}$, apex emarginate; lateral lobes obovate or elliptic, $12.5-22 \times 7-17 \mathrm{~mm}$, apices emarginate; adaxial lobes as lateral lobes but 5.5 - $13 \mathrm{~mm}$ wide. Stamens inserted $2.5-6 \mathrm{~mm}$ from base of corolla; filaments 19 - 29 mm long; anthers 3.4 - $5.5 \mathrm{~mm}$ long; lateral staminodes $0.5-2 \mathrm{~mm}$ long. Ovary glabrous or rarely shortly antrorse-pubescent towards apex; style glabrous; stigma 1.8 - 4 mm long. Capsule 2-seeded, 14 - $17 \mathrm{~mm}$ long, glabrous or rarely shortly antrorsepubescent on beak (see note); seeds $6-7.5 \times 4.5-6.5$ mm. Fig. $4 \mathrm{~A}-\mathrm{B}$.

DISTRIBUTION. Namibia (Kavango East, Kavango West, Kunene, Oshikoto, Otjozondjupa and Zambezi Regions); widespread in southern tropical Africa: Zambia, Zimbabwe, Mozambique and NE South Africa (Limpopo Prov.). Also likely to occur in SE Angola (Cuando Cubango Prov.) and N Botswana; Map 2.

SELECTED COLLECTIONS STUDIED. (Total of 17 Namibian collections seen). NAMIBIA. Grootfontein, Tsintsabis, Kuringkuru, fl. Jan./Feb. 1934, Schoenfelder S.526 (PRE!); Etosha Gamepark, NE Sandveld area, fl. Feb. 1967, Tinley 1567/1061 (WIND!); Grootfontein Distr., Choantsas, fl. 10 April 1973, Volk 251 (M!); eastern Caprivi, Impalela Is., fl. \& fr. 16 March 1976, du Preez 9 (17285) (PRE!, WIND!); myl 60, W met grondpad $-15 \mathrm{~km}, 110 \mathrm{~km}$ vanaf Rundu met teerpad, fl. 21 Feb. 1985, Potgieter 161 (K!, WIND!); Omytheya, $25 \mathrm{~km} \mathrm{~N}$ of 61 Mech. Inf. Batt. Grp. Camp on N/S chopline, fl. 4 Jan. 1989, Bodenstein 615 (PRE!); Kavango, Mangetti area, fl. Jan. 1994, Horn 168 (PRE, WIND!); Bushmanland, S of Rundu, about $10 \mathrm{~km}$ from Omatako Omuramba on road to Sonop Agricultural Station, fl. 7 March 1995, Burgoyne 3323 (PRE!); on road to Tsumkwe, $50 \mathrm{~km} \mathrm{NE}$ of Grootfontein, fl. 7 March 1995, Germishuizen 7629 (PRE!, WIND!) \& idem, Germishuizen 7630 (K!, PRE!, WIND!); 
Grootfontein Distr., Sonop South, about $7 \mathrm{~km} \mathrm{~N}$ of gate to Moedhou, fl. 7 Feb. 2000, Strohbach BS4577 (WIND!); Kaokoveld, fl. 8 March 2003, Schubert SS 88 (WIND!) \& idem, Schubert SS100 (WIND!); Rundu Distr., c. $1 \mathrm{~km}$ SW of Mile 46 Livestock Development Centre, fl. 8 Feb. 2006, Strohbach et al. BS6302 (WIND!).

HABITAT \& ECOLOGY. Shrubland and woodland, usually on freely drained sandy soils, including on dune slopes and dune streets, often recorded from Terminaliadominated woodland and thicket, occurring at c. 1150 - 1350 m elevation. Elsewhere within its range, Barleria matopensis is often associated with riparian habitats. In Namibia, it is found in the following vegetation types of Mendelsohn et al. (2002): the Western Highlands and Karstveld sub-divisions of the Acacia Tree-andshrub Savanna, and the North-eastern Kalahari Woodland and Caprivi Floodplains sub-divisions of the Broadleaved Tree-and-shrub Savanna.

CONSERVATION STATUS. Barleria matopensis is widespread in southern Africa, with an EOO in excess of 795,000 $\mathrm{km}^{2}$, and is locally common in parts of southern Zambia and northen Zimbabwe. It was assessed as of Least Concern - LC by Darbyshire (2015) and this assessment is upheld here. However, it appears to be rather scarce in the western part of its range and is often recorded as uncommon or rare on the Namibian specimens seen. NOTES. Barleria matopensis is a rather variable species; the description above covers the full range of variation across its broad geographical range. du Preez 9 (17285) from Zambezi region matches the widespread form from southern Zambia and northern Zimbabwe (form A of Darbyshire 2015; type A here) which has slender calyces (posterior lobe $8.5-17.5 \times 3-5.5 \mathrm{~mm}$, l:w ratio $2.6-5.8: 1$ ) with the hairs often restricted to the margins and main veins (see Fig. 4A \& B). Elsewhere in northern Namibia, the calyces are more densely hairy throughout, including more numerous glandular hairs, and are broader (posterior lobe typically 9 $16 \times 5.5-7 \mathrm{~mm}$, l: $\mathrm{w}$ ratio $1.9-2.4: 1)$. This variant (type $\mathrm{C}$ here) was previously separated as B. albi-pilosa Schinz. However, there is some overlap between these two variants, and in fact the type specimen of B. matopensis has slender but rather densely hairy calyces including numerous glandular hairs, and so is itself intermediate. The situation is further complicated by form B of Flora Zambesiaca (Darbyshire 2015; type $B$ here) from drier regions in the southeast of its range. This variant is similar to the north Namibian material, having similarly broad (though often larger) calyces (posterior lobe $15-18.5 \times 6-12$, l: w ratio 1.4 - 2.4: 1) with a similarly dense indumentum. However, type B has more tardily glabrescent foliage than the Namibian plants and often has glandular hairs along the young stems, these lacking in the Namibian plants. In light of this complex picture, we currently consider B. matopensis to be best treated as a single, variable taxon, but a key to the three forms is provided below.

Schubert SS100 from the Kaokoveld is unusual in having short antrorse hairs on the beak of the immature capsules, these being glabrous in all other material seen. The only other specimen seen from that region, Schubert SS88, has glabrous ovaries; it is otherwise a good match for SS100. More material is desirable from the Kaokoveld to assess the extent of variation there.

\section{Key to infraspecific variants of Barleria matopensis}

1 Outer calyx lobes with white antrorse or tomentellous hairs often restricted to the margin and main veins (2 veins on anterior lobe, midrib on posterior lobe) or to the margin only, glandular hairs usually restricted to the margin or absent, posterior lobe $3-5.5 \mathrm{~mm}$ wide, l:w ratio $2.6-5.8$ : 1 (NE Namibia to W Mozambique) . . . . . . type A

Outer calyx lobes with more dense white antrorse or tomentellous hairs throughout, glandular hairs restricted to the margin or more widespread and numerous; posterior lobe $5.5-12 \mathrm{~mm}$ wide, l:w ratio $1.4-2.4$ : 1 . . 2

2 Flower-bearing portions of stems with \pm numerous short glandular hairs; leaves only tardily glabrescent, often appearing silvery grey due to dense tomentellous hairs (SE Zimbabwe, SW Mozambique, NE South Africa). type B

Stems lacking glandular hairs; leaves \pm soon glabrescent $(\mathrm{N}$ Namibia $\ldots \ldots \ldots \ldots$. . . . . . . type

41. Barleria violacea Hainz ex Suess. E Merxm. (Suessenguth \& Merxmüller 1955: 67); Meyer (1957: 385; 1968: 18); Craven (1999: 152); Welman (2003: 94); Klopper et al. (2006: 5); Darbyshire et al. (2012: 766); Klaassen \& Kwembeya (2013: 130). Type: Namibia, nähe Outjo, Südpad-anfang, fl. 24 Feb. 1953, Schwerdtfeger in Walter 2/71 (holotype M! [M0109789]; isotype WIND! [WIND000031807]).

Erect dwarf perennial herb to $10-15 \mathrm{~cm}$ tall, severalstemmed from base; young stems white-tomentellous, mature stems soon woody and glabrescent, with pale grey bark. Leaves narrowly oblong-elliptic or lanceolate, $1.3-3.2 \times 0.4-0.9 \mathrm{~cm}$ (1:w ratio $3-4: 1)$, base cuneate, apex acute to obtuse, surfaces at first white tomentellous but soon glabrescent except along midrib beneath; lateral veins $4-6$ pairs, inconspicuous; petiole to $3 \mathrm{~mm}$ long. Inflorescences axillary, singleflowered; bracts foliaceous; peduncle to $1.5 \mathrm{~mm}$ long, tomentellous; bracteoles oblanceolate or elliptic-oblanceolate, $11.5-16 \times 2-3.5 \mathrm{~mm}$, base attenuate, 


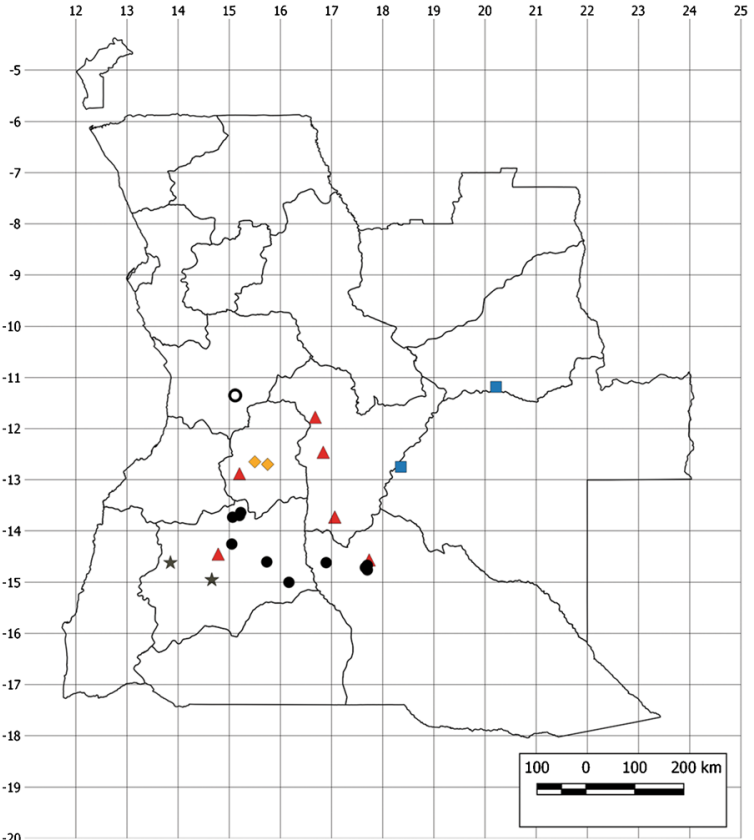

Map 4. Distribution of Barleria antunesii (grey stars), B. kacondensis subsp. kacondensis (black circles), $B$. kacondensis subsp. glabrescens (yellow diamonds), B. thunbergiiflora (blue squares), B. sp. (= Teixeira s.n.) (white-centred black circle) and $B$. eburnea (red triangles).

apex obtuse or rounded, glabrous; pedicel to $1 \mathrm{~mm}$ long. Calyx anterior lobe broadly ovate-elliptic, $10-13 \times$ (5.5-) 8-10 mm, base somewhat attenuate, apex shortly bifid for up to $4.5 \mathrm{~mm}$, surface glabrous; posterior lobe somewhat larger, to $14 \mathrm{~mm}$ long, apex acute; lateral lobes linear-lanceolate, c. $3 \mathrm{~mm}$ long. Corolla c. 15 $20 \mathrm{~mm}$ long, pale purple, glabrous externally; tube cylindrical, c. 7 - 8.5 mm long; limb in " $4+1$ " configuration, abaxial lobe shortly offset, lobes obovate, c. $8.5-$ $11 \mathrm{~mm}$ long, abaxial lobe to $6-6.5 \mathrm{~mm}$ wide, lateral and adaxial lobes somewhat narrower. Stamens with filaments c. $10 \mathrm{~mm}$ long; anthers c. 2.8 - $3 \mathrm{~mm}$ long; lateral staminodes $3 \mathrm{~mm}$ long (fide Suessenguth \& Merxmüller 1955). Pistil glabrous; stigma linear, apex bilobed. Capsule not seen.

DISTRIBUTION. Endemic to Northern Namibia (Kunene Region), known only from the type collection; Map 2.

COLLECTION STUDIED. NAMIBIA. Nähe Outjo, Südpadanfang, fl. 24 Feb. 1953, Schwerdtfeger in Walter 2/71 (M! holotype, WIND! isotype).

HABITAT \& ECOLOGY. The habitat of the single known specimen was not recorded. The type locality falls within the Karstveld Acacia Tree-and-shrub Savanna vegetation type of Mendelsohn et al. (2002).

CONSERVATION STATUS. This species is known only from the type specimen and has not been rediscovered in over 65 years. Assuming that it is indeed a good species (see Notes), it is clearly rare and highly localised and may well prove to be threatened, but in view of the lack of habitat information or population data, it must currently be considered Data Deficient - DD.

NOTES. The plants on the type collection appear to represent young regrowth from a perennial, somewhat woody base. Suessenguth \& Merxmüller (1955) noted in the protologue the similarity of this species to Barleria matopensis but did not record the differences. The broad glabrous calyx lobes and the small glabrous corollas of B. violacea appear to be diagnostic but we cannot entirely rule out the possibility that this is an aberrant, stunted specimen of B. matopensis. Efforts to rediscover this species have so far been hindered by the rather vague type locality and lack of habitat notes.

42. Barleria phaylopsis Milne-Redh. (Milne-Redhead 1940: 65); Klopper et al. (2006: 4); Darbyshire \& Ndangalasi (2009: 131 - 132); Darbyshire (2015: 107). Type: Zambia, Solwezi Distr., Mbulungu Stream, W of Mutanda Bridge, fl. \& fr. 9 July 1930, Milne-Redhead 690 (lectotype K (sheet 1)! [K000394499], chosen by Darbyshire 2015; isolectotypes BR* [BR0000006268381], K (sheet 2)! [K000394498], PRE* [PRE0130330-0]).

Barleria affinis De Wild. (De Wildeman 1903: 140), nom. illegit., non B. affinis C.B.Clarke (1901: 50). Type: D. R. Congo, Katanga, Lukafu, fl. July 1900, Verdick 561 (holotype BR! [BR0000006268343]).

Suffruticose herb with several decumbent or creeping stems 15 - $30 \mathrm{~cm}$ long from a woody rootstock; stems hispid, hairs (buff-) golden, ascending or spreading. Leaves subsessile, blade oblong-elliptic or oblanceolate, $4-9.5 \times 1.2-3 \mathrm{~cm}$ (l:w ratio $2.2-5.6$ : 1), base cuneate, apex acute or lower leaves obtuse, with numerous (buff-) golden hispid hairs on margin and midrib only or evenly distributed on both surfaces; lateral veins $4-8$ pairs, these and reticulate tertiary veins prominent. Inflorescences terminal and sometimes also in the uppermost leafy axils, densely spiciform or subcapitate, $2-5.5 \mathrm{~cm}$ long, each axil single-flowered or lowermost axils 2 - 3-flowered; bracts oblanceolate or narrowly elliptic, sometimes flushed purple distally or throughout, $9.5-15.5 \times 1.5-4.5 \mathrm{~mm}$ (basal pairs up to $23 \times 7.5 \mathrm{~mm}$ ), base cuneate, apex acute, \pm densely glandular-pilose and with subappressed stiff hairs at least on margin and midrib, those on margin sometimes with swollen base; bracteoles as bracts but (elliptic-) oblanceolate to linear, $9-14.5 \times 1-2 \mathrm{~mm}$, glandular hairs more numerous; flowers sessile. Calyx often flushed purple at least towards apex, pale at base; anterior lobe narrowly oblong or subulate, 10 $15.5 \times 1.5-2.5 \mathrm{~mm}$, apex bifid for $2.5-8 \mathrm{~mm}$, indumentum as bracteoles, 2 parallel principal veins prominent; posterior lobe narrowly lanceolate or subulate, $10-16.5 \times 2-2.7 \mathrm{~mm}$, apex acute, midrib only prominent; lateral lobes linear, 9 - $13.5 \mathrm{~mm}$ long. 
Corolla 17 - 22 mm long, white, pink, lilac or bright blue, with or without purple guidelines, lateral lobes sparsely pubescent externally; tube cylindrical, 9.5 $11.5 \mathrm{~mm}$ long; limb in " $2+3$ " configuration, abaxial lobe obovate or broadly so, $6-10.5 \times 4.5-7 \mathrm{~mm}$, apex emarginate; lateral lobes obovate, $7-10.5 \times 3-6 \mathrm{~mm}$, apices emarginated or rounded; adaxial pair fused for $0.7-5 \mathrm{~mm}$, free portions oblanceolate to subulate, 4.5 $-10 \times 1.5-4 \mathrm{~mm}$. Stamens inserted $2.5-3.5 \mathrm{~mm}$ from base of corolla tube; filaments 9.5 - $15.5 \mathrm{~mm}$ long; anthers 2.5 - $3 \mathrm{~mm}$ long; lateral staminodes $0.25-$ $0.8 \mathrm{~mm}$ long. Ovary densely puberulous at least distally, sometimes also with short glandular hairs at apex; style with few hairs towards base; stigma 1.2 $1.9 \mathrm{~mm}$ long. Capsule 2-seeded, 13 - $14.5 \mathrm{~mm}$ long including beak $5-5.5 \mathrm{~mm}$ long, puberulous; seeds \pm 6 $\times 5 \mathrm{~mm}$. Fig. $4 \mathrm{C}$.

DISTRIBUtION. Angola (Cuando Cubango Prov.); Zambia, southern D. R. Congo; Map 5.

COllection Studied. ANGola. Serpa Pinto [Menongue], a $27 \mathrm{~km}$ do R. Cuebe para Caiundo, fl. \& fr. 29 June 1966, Mendes dos Santos 2049 (LUBA!).

HABITAT \& ECOLOGY. The single Angolan specimen seen was recorded from open miombo (Brachystegia) woodland at $\pm 1400 \mathrm{~m}$ elevation, which is in keeping with the habitat in the rest of its range. It is a species of the Zambezian phytochorion (White 1983).

CONSERVATION STATUS. This species is scattered in the miombo woodland belt of southern central Africa, with a large EOO of c. $200,000 \mathrm{~km}^{2}$. However, to the authors' knowledge, it is only known from eight collections and one photographic record and it appears to be naturally rare. Further botanical exploration across its large range is likely to reveal further subpopulations of this species, and miombo woodland remains extensive in large parts of its range, although the easternmost locality of Mbala is threatened by intensive settlement and agriculture (Darbyshire 2015). It is currently assessed as of Least Concern - LC but with further information on population size and threats desirable.

NOTES. Barleria phaylopsis is here recorded in Angola for the first time, extending its known range westwards by several hundred kilometres from NW Zambia. Although unexpected, this range extension is not unprecedented; for example Justicia subsessilis Oliv. has recently been recorded from Angola for the first time, a long way west of its previously known Zambian range (Darbyshire \& Goyder 2019). It is possible that several other Zambesian miombo woodland species of Barleria may extend into the poorly botanised Cuando Cubango and Moxico Provinces of Angola.

43. Barleria lugardii C.B.Clarke (1899: 161); Meyer (1957: 382; 1968: 15); Balkwill \& Balkwill (1997: 539, figs. 2J, 6U \& 12L); Craven (1999: 152); Welman (2003: 94); Klopper et al. (2006: 4); Darbyshire (2010: 402; 2015: 106, fig. 8.6.43); Darbyshire et al. (2012: 766); Klaassen \& Kwembeya (2013: 129). Type: Botswana, Khwebe, fl. \& fr. Jan. 1897, Lugard 128 (holotype K! [K000394510]).

Barleria breyeri Oberm. (Obermeyer 1933: 151). Type: Namibia, Klein Namutoni, [date unknown], Breyer in Transvaal Mus. 20642 (holotype PRE, n.v.).

Perennial herb or subshrub, 10 - $60 \mathrm{~cm}$ tall; stems strigose with white anvil-shaped hairs, young stems often also patent glandular-pubescent; mature stems with pale greyish bark, glabrescent. Leaf buds densely whitestrigose. Leaves on petiole $0-5 \mathrm{~mm}$ long; blade ovate to elliptic, $1.9-6 \times 0.8-2.5 \mathrm{~cm}$, base attenuate, apex acute or obtuse, margin and midrib beneath sparsely strigose, sometimes with short glandular hairs towards base; lateral veins $3-5$ pairs. Inflorescences 1 - 3flowered, axillary but in densely-flowered plants forming a terminal racemose thyrse; bracts foliaceous, often narrowing upwards; bracteoles linear or linearoblanceolate to narrowly elliptic, $6-22 \times 0.5-3.5$ $\mathrm{mm}$, indumentum as leaves but with glandular hairs often more widespread; flowers (sub)sessile. Calyx somewhat accrescent; anterior lobe ovate, $5.5-14 \times$ $2-6.5 \mathrm{~mm}$, apex attenuate, entire or bifid with linear lobes $0.5-4.5 \mathrm{~mm}$ long, strigose on margin and principal veins, often also with scattered glandular hairs, venation palmate to subparallel; posterior lobe $6.5-16.5 \times 2.5-7.5 \mathrm{~mm}$, margin often involute and partially enveloping anterior lobe, apex attenuate; lateral lobes lanceolate, $3.5-6.5 \mathrm{~mm}$ long. Corolla 16 - $21 \mathrm{~mm}$ long, white, lateral lobes pubescent externally with mixed glandular and eglandular hairs; tube cylindrical, 7 - $10 \mathrm{~mm}$ long, somewhat expanded towards mouth; limb in " $1+3$ " configuration; abaxial lobe offset by $0.8-2 \mathrm{~mm}$, obovate, $9-11.5 \times 5-7$ $\mathrm{mm}$, apex rounded or shallowly emarginate; lateral lobes elliptic or obovate-elliptic, $7.5-10.5 \times 4.5-6.5$ $\mathrm{mm}$, apices rounded or obtuse; adaxial lobe elliptic or oblong-elliptic, $7.5-10.5 \times 3.5-5 \mathrm{~mm}$, apex conspicuously emarginate. Stamens inserted 2 $3.5 \mathrm{~mm}$ from base of corolla; filaments $13-20 \mathrm{~mm}$ long; anthers 2 - $3 \mathrm{~mm}$ long; lateral staminodes 0.5 $0.8 \mathrm{~mm}$ long. Ovary densely pubescent distally; style pubescent at base; stigma $0.8-1.2 \mathrm{~mm}$ long. Capsule $11-15.5 \mathrm{~mm}$ long, shortly pubescent; seeds $5.5-7 \times$ $4.5-6 \mathrm{~mm}$. Fig. 4D - G.

DISTRIBUTION. Namibia (Kavango East, Kavango West, Kunene, Oshikoto, Otjozondjupa and Zambezi Regions); Tanzania, Botswana, Zimbabwe, Mozambique. Also likely to occur in southwest Angola (Cuando Cubango Prov.). Map 5.

SELECTED COLLECTIONS STUDIED. (Total of 23 Namibian collections seen). NAMIBIA. Farm Lazy Spade 30 miles 

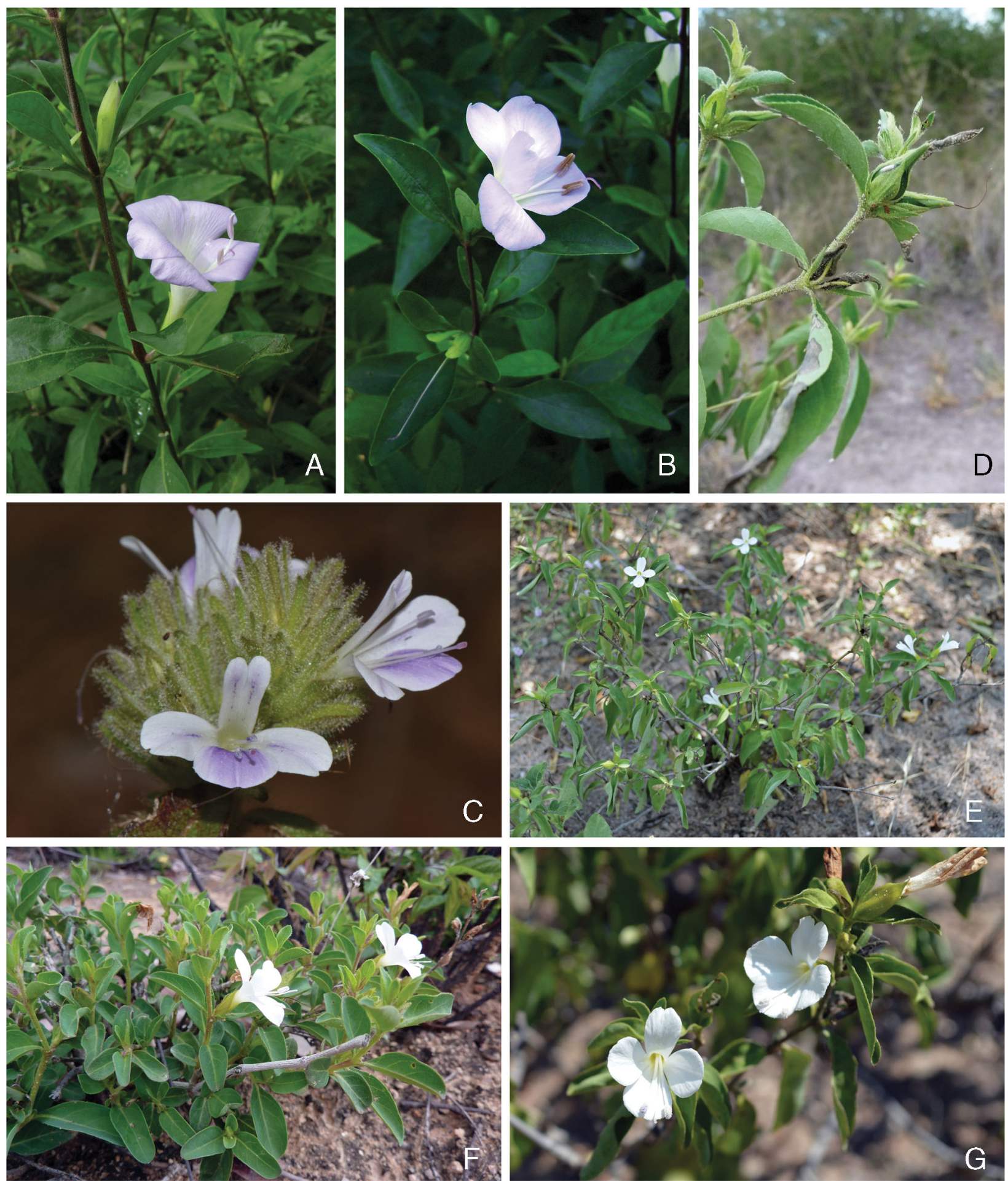

Fig. 4. A, B Barleria matopensis. habit, flowering branches, Zambia. C Barleria phaylopsis, inflorescence, Zambia. D - G Barleria lugardii: D fruiting branch (collected as Tripp \& Dexter 802, Namibia); E \& F habit; G flowers, Namibia. E, G collected as Aiyambo et al. 331; F collected as Tripp et al. 4065. PHOTOS: A, B H. PICKERING, C W. MCCLELAND, D, F E. A. MANZITTO-TRIPP, E, G I. DARBYSHIRE. C reproduced from Dressler et al. (2014+) with permission of the photographer.

NE of Outjo, fl. \& fr. 1 April 1955, de Winter 3027 (K!, M!, PRE!, WIND!); Kaprivi side of the river at Bagani Pontoon, fl. 19 Jan. 1956, de Winter E̋ Wiss 4334 (K!, M!, PRE!, WIND!); 6 miles N of Ohopoho, fl. \& fr. 27
March 1957, de Winter Eॄ Leistner 5206 (K!, M!, PRE!, WIND!); Grootfontein-Nord/Caprivizipfel, Popa-fälle, ufer und inseln des Okavango, fl. \& fr. 9 March 1958, Merxmüller E̋ Giess 2009 (M!, PRE, WIND!); E Caprivi 


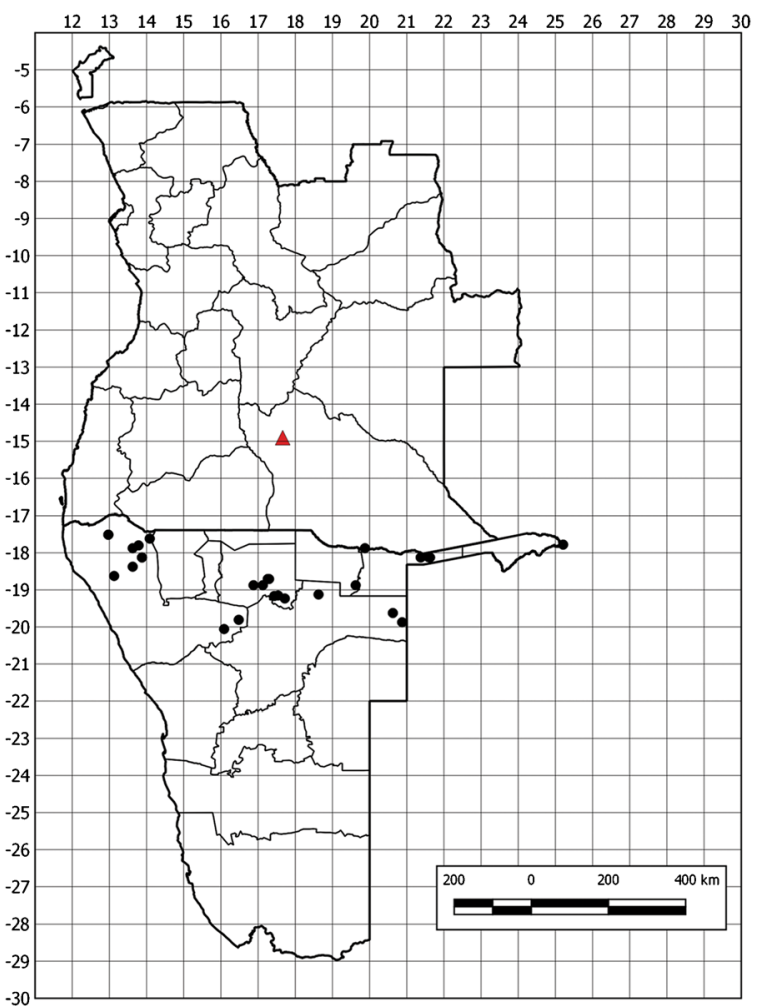

Map 5. Distribution of Barleria phaylopsis (red triangle) and B. lugardii (black circles).

zipfel, Mpilila Island, fl. 13 Jan. 1959, Killick $\mathcal{E}$ Leistner 3355 (K!, PRE!, WIND!); pfanne bei Tsumkwe, fl. 14 Jan. 1971, Giess et al. 11068 (M!, PRE!, WIND!); 5 km W Ombazu, fl. \& fr. 21 March 1974, Merxmüller \& Giess 30458 (M!, WIND!); Farm GR/TS 932, fl. 17 Feb. 1976, Giess E Müller 13949 (M!, PRE!, WIND!); Tsumeb, along road D 3043 to Lake Guinas, fl. \& fr. 1 Feb. 2006, Bartsch et al. SB2281 (WIND!); near Hoba Meteorite, W of Grootfontein, fl. \& fr. 20 March 2010, Tripp E Dexter 802 (K!, RSA, WIND); Gelunksanker Farm on D3001, c. $10 \mathrm{~km} \mathrm{E}$ of D3001 and B1 junction, fl. \& fr. 21 March 2010, Tripp E Dexter 810 (K!, RSA, WIND); $20 \mathrm{~km} \mathrm{SW}$ of Etengwa on road to Otjitanda, fl. \& fr. 16 Jan. 2013, Tripp et al. 4065 (COLO!, K!, WIND!); Tsumeb Distr., along the gravel road D3001 to Tsintsabis $\pm 2 \mathrm{~km}$ from B1 road, fl. 18 April 2015, Aiyambo et al. 331 (K!, WIND!).

HABITAT \& ECOLOGY. Barleria lugardii is recorded from shady situations in dry woodland and thicket, with Acacia (Vachellia and/or Senegalia) spp., Colophospermum mopane etc., occasionally on rocky hillslopes. It is recorded on sandy or stony soils including interdunal streets, or sometimes on calcareous soils. It occurs at $915-1500 \mathrm{~m}$ elevation. In Namibia, it is often found growing in close proximity to B. mackenii Hook.f. (see below). It occurs in the following vegetation types of Mendelsohn et al. (2002): the Western Highlands and Karstveld sub-divisions of the Acacia Tree-and-shrub Savanna, and the Northeastern Kalahari Woodland, Northern Kalahari and Caprivi Mopane Woodland of the Broadleaved Treeand-shrub Savanna.

CONSERVATION STATUS. This is a widespread and locally common species of various type of dry woodland, with an EOO of over 1,250,000 $\mathrm{km}^{2}$. It is considered to be of Least Concern - LC (Darbyshire 2015). In Namibia, it is fairly frequent and widespread in the north and is not threatened.

NOTES. Barleria lugardii is easily recognisable as it is the only species of Barleria in our region with a 4lobed corolla; this is a result of near-complete fusion of the two adaxial lobes to form a single, emarginate lobe (Fig. 4G).

NOTE ON SPECIES 44 - 49: THE BARLERIA LANCIFOLIAMACKENII COMPLEX. The following six species form a taxonomically challenging complex. Barleria lancifolia and B. mackenii are both widely distributed across southern Africa and become particularly common and variable in the current study area, where several closely allied taxa are also recorded. An in-depth molecular phylogenomic study is desirable to fully delimit the taxa within this group, but at present we have separated out the most distinctive elements and have made notes on the range of variation within B. lancifolia and B. mackenii in the study area. Although usually easily separable, there are rare specimens that appear intermediate between $B$. lancifolia and $B$. mackenii, suggesting that there may be occasional hybridisation, for example, $H$. Wanntorp $\mathcal{E} H$. E. Wanntorp 595 (K!) from Grootfontein and Giess et al. 5554 (WIND!) from Maltahoehe Distr. in Namibia. Similarly, Tripp E Dexter 6938 (COLO!, K!) from between Caraculo and Bentiaba in Angola is potentially intermediate between $B$. mackenii and $B$. gossweileri given its geographic location. Rare intermediate specimens were also noted in southern Africa by Darbyshire (2015).

44. Barleria mackenii Hook.f. (Hooker 1870: t. 5866); Clarke (1899: 160); Obermeyer (1933: 146); Meyer (1957: 382; 1968: 16); Balkwill \& Balkwill (1997: fig. 12A, K); Craven (1999: 152); Welman (2003: 94); Klopper et al. (2006: 4); Darbyshire et al. (2012: 766); Klaassen \& Kwembeya (2013: 129); Darbyshire (2015: 98, fig. 8.6.43). Type: South Africa, "Latin" Goldfields (cited as "Tati Goldfields" by Clarke 1899), fl. in hort., Natal Bot. Gard. 1869 - 1870, McKen s.n. (lectotype K (sheet 1)! [K000951846], selected by Darbyshire 2015; isolectotype $\mathrm{K}$ (sheet 2)! [K000951847]).

Barleria jucunda Benoist (1950: 18), nom illegit., non B. jucunda Lindau (1896: 75). Type: Angola, Moçâmedes, Hoque, fl. 15 April 1938, Abreu 70 (syntypes BM! [BM001015787], P* [P00434413]). 
Barleria jucunda Benoist var. pilosula Benoist (1950: 18), nom illegit. Type: Angola, Benguela litoral, Lengue, fl. 17 Dec. 1932, Gossweiler 9717 (syntypes B M! [ BM001014867], K! [K000913674]).

Barleria cunenensis Benoist (1950: 19); Klopper et al. (2006: 4). Type: Angola, Huíla, Ruacaná, R. Cunene, fl. 7 June 1937, Gossweiler 10883 (lectotype BM! [BM001010580], selected here).

Barleria galpinii sensu Craven (1999: 152), quoad Burgoyne 3273, non C.B.Clarke (1899).

Barleria gibsonii sensu Shendage \& Yadav (2010: 119), pro parte, non Dalzell (1850: 339).

Subshrub or suffruticose herb, branches erect, straggling or trailing, 15 - $120 \mathrm{~cm}$ long; stems with upper internodes strigulose, lower portion densely (rarely more sparsely) and minutely white-velutinous. Leaves on petiole to $12 \mathrm{~mm}$ long or subsessile; blade ovate, lanceolate or elliptic, $3-12 \times(0.7-) 1.2-4.4 \mathrm{~cm}(1: \mathrm{w}$ ratio $2-4(-5.75)$ : 1$)$, base attenuate, apex attenuate or acute, rarely obtuse, apiculate, leaf buds whitestrigulose and often white-velutinous, mature leaves \pm glabrescent except margin and veins beneath strigulose, upper surface often sparsely strigose, or surfaces sometimes also puberulous; lateral veins $4-6$ pairs. Inflorescences axillary in the distal portion of the branches, 1 - 3-flowered; peduncle 1 - $8 \mathrm{~mm}$ long; bracts foliaceous; bracteoles \pm ascending, those at distal axils linear to narrowly oblanceolate, $7-20 \times$ $0.5-2.5 \mathrm{~mm}$, those at lowermost fertile axils often larger, narrowly elliptic or oblanceolate, $20-37 \times 2.5-$ $9.5 \mathrm{~mm}$, margin and midrib strigose; pedicels $1.5-$ $5 \mathrm{~mm}$ long. Calyx accrescent; anterior lobe broadly ovate, $13.5-24 \times 11-21 \mathrm{~mm}$ in flower, $19-32 \times 18-$ $25 \mathrm{~mm}$ in fruit, base cordate or shallowly so, apex
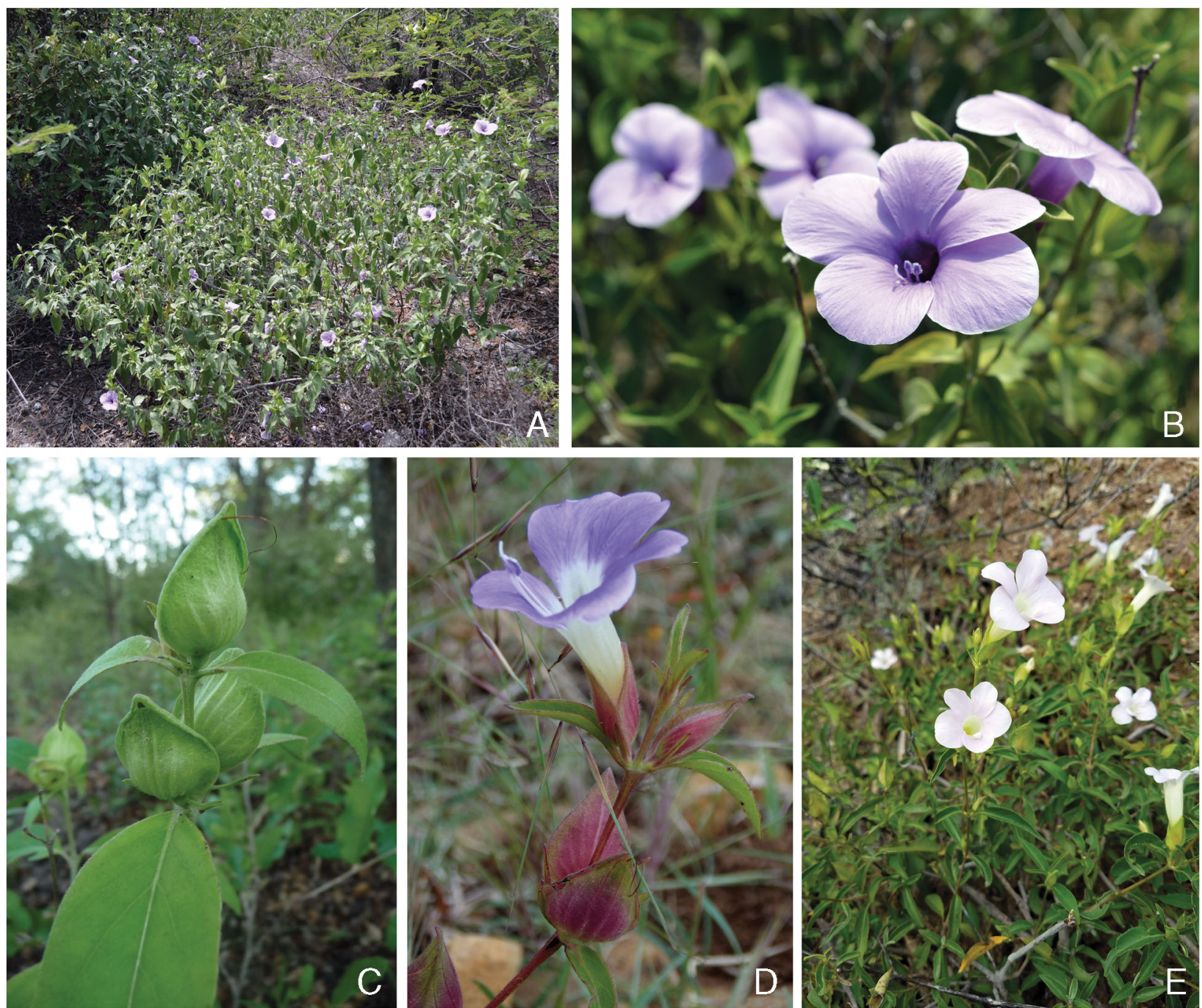

Fig. 5. Barleria mackenii. A habit; B flowers, typical form; C mature calyces post-anthesis; D flowers showing corolla and calyx colour variation; E variant with almost white flowers. A, B collected as Nanyeni et al. 1049, Namibia; C collected as Tripp et al. 811, Namibia; D Angola; E collected as Tripp \& Dexter 6914, Angola. PHOTOS: A \& B I. DARBYSHIRE, C, E E. A. MANZITTO-TRIPP, D F. M. P. GONÇALVES. 
notched for up to $4 \mathrm{~mm}$ or acute to obtuse, external surface strigose on main veins and margin, with or without fine puberulous hairs between the veins, internal surface puberulous to tomentellous with mixed eglandular and some glandular hairs or only the former, venation palmate, prominent externally; posterior lobe as anterior lobe but 15.5 - $28 \mathrm{~mm}$ long in flower, 22 - $35 \mathrm{~mm}$ long in fruit, apex acute or obtuse, margin often somewhat involute; lateral lobes linear-lanceolate, $7.5-11.5 \mathrm{~mm}$ long in flower, 11 $14.5 \mathrm{~mm}$ in fruit, eglandular- and glandular-pubescent. Corolla 31 - $52 \mathrm{~mm}$ long, blue, mauve or violet usually with a darker throat, rarely white throughout, throat and limb eglandular- and glandular-pubescent or sparsely so externally; tube $14.5-24 \mathrm{~mm}$ long, basal $3.5-6 \mathrm{~mm}$ cylindrical, $4-6 \mathrm{~mm}$ wide, then abruptly funnel-shaped, throat $8-12.5 \mathrm{~mm}$ wide; limb subregular or in weak " $4+1$ " configuration, all lobes usually imbricate even at anthesis; abaxial lobe offset by $1.5-4.5 \mathrm{~mm}$, obovate-orbicular or elliptic, $13.5-21$ $\times 12-18 \mathrm{~mm}$, apex slightly emarginate; lateral lobes as abaxial lobe but 12.5 - $21.5 \mathrm{~mm}$ wide; adaxial lobes 9 $15 \mathrm{~mm}$ wide. Stamens inserted $4-6 \mathrm{~mm}$ from base of corolla tube; filaments 12.5 - $22.5 \mathrm{~mm}$ long; anthers 3 - $4.2 \mathrm{~mm}$ long; lateral staminodes 0.5 - $2.2 \mathrm{~mm}$ long. Ovary eglandular- and glandular-puberulous or glabrous; style glabrous; stigma $2-3 \mathrm{~mm}$ long. Capsule 2seeded, 15.5 - $21.5 \mathrm{~mm}$ long, eglandular- and glandular-puberulous or more rarely glabrous; seeds $5.5-7.5 \times 5-7 \mathrm{~mm}$. Fig. 5 .

DISTRIBUtION. Angola (Benguela, Cuando Cubango, Cuanza Sul, Cunene, Huíla, Luanda and Namibe Provs.), Namibia (Kavango East, Kavango West, Kunene, Ohangwena, Oshana, Oshikoto, Otjozondjupa and Zambezi Regions); widespread elsewhere in southern Africa: Zambia, Zimbabwe, Botswana and South Africa (Limpopo \& Mpumulanga Provs.); Map 6.

SELECTED COLLECTIONS STUDIED. (Total of 96 Angolan and Namibian collections seen). ANGOLA. Anha, fl. \& fr. March 1907, Gossweiler 3623 (BM!, K!); between Gambos Fort and Mission Station, fl. \& fr. 15 May 1909, Pearson 2519 (K!); Tchimbolelo, entre Gambos e Quihita, fl. 11 Feb. 1956, Mendes 1697 (LUBA!); Huíla, Fazenda da Banja, fl. \& fr. 21 Dec. 1961, Barbosa E Moreno 9748 (K!, LUBA!); Chicungo, fl. 26 March 1962, Teixeira $\mathcal{E}$ Almeida 5733 (LUBA!); Luanda, foz de R. Cuanza, fl. \& fr. 8 Oct. 1964, Bozeira et al. 10880 (LUBA!); Sá da Bandeira [Lubango], próx. da Cacula, fl. 8 Feb. 1966, Sousa 936 (LUAI!); Cuanza Sul, picada para o Pau do Caçador Gungo ao km 44 de Novo Redondo [Sumbe], fl. 19 March 1967, Teixeira et al. 11437 (LISC!); Cuanza Sul, na estrada para Vila Nova de Seles ao km 7, fl. 3 April 1967, Teixeira et al. 11325 (LISC!); Cuanza Sul, picada Porto Amboim - Baroo do Longa a $35 \mathrm{~km}$ de Porto Amboim, fl. \& fr. 19 May 1967, Teixeira et al. 11606

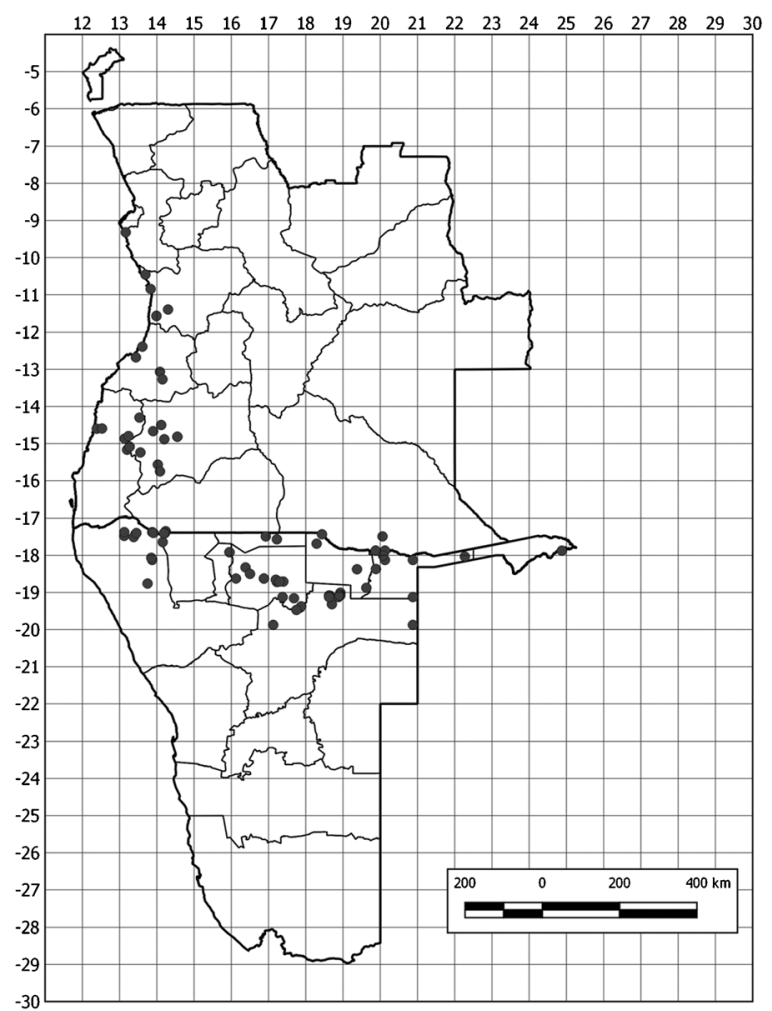

Map 6. Distribution of Barleria mackenii.

(LISC!); Sá da Bandeira [Lubango], Leba, fr. 20 May 1968, Sousa 1278 (LUAI!); idem, fl. \& fr. 24 May 1968, Sousa 1277 (LUAI!); Huíla, Chibia, ao km 16.5 da Estrada Chibia - Hunguéria, fl. \& fr. 6 May 1971, Borges 188 (LISC!, LUBA!, PRE!); Cuanza Sul, estrada de Porto Amboim, andados $35 \mathrm{~km}$ do cruzamento com a estrada Cabela - Novo Redondo [Sumbe], fl. 23 Jan. 1972, Raimundo et al. 1003 (LISC!); Humpata, junto as Quedas da Leba, fl. \& fr. 1 April 1972, Borges 355 (LUBA!); Tchivinguiro Capangombe, Bruco, fl. \& fr. 7 March 1973, Bamps et al. 4031 (BR, K!); Cubal - Benguela, km 50, fl. \& fr. 12 April 1973, Bamps et al. 4454 (BR, K!, LISC!, WAG!); Vila Arriaga [Bibala] - Moçâmedes, km 30, fl. \& fr. 14 April 1973, Bamps et al. 4490 (BR, K!, LISC!, PRE!, WAG!); Benguela, estrada Lobito - Novo Lisboa [Huambo], andados 4 km, fl. 16 May 1974, Cardoso de Matos 188 (LISC!); Lubango, Quipungo, fl. \& fr. 27 April 1978, André Ẽ Ferreira 213 (LUAI!); idem, fl. 27 April 1978, Daniel 1706 (LUAI!); Rápidos M'Pupo, Cuito R., between Dingo and Lumeta, fr. 17 April 2013, Harris Eै Murray-Hudson 822 (K!); between Bibala and Assunçao, fl. 10 April 2017, Tripp Ẽ Dexter 6914 (COLO!, K!, LUBA!); 18.2 km W along unnamed road $4 \times 4$ track that leaves $\mathrm{W}$ directly towards ocean from main way between Caraculo and Bentiaba, $\mathrm{N}$ of crossing of Rio Mucungo, road to "Pupa", fl. 12 April 2017, Tripp Ẽ Dexter 6932 (COLO!, K!, LUBA!); 4.4 km from split Guntra for Ruacana and Chitado, fl. \& fr. 21 
April 2017, Tripp Eீ Dexter 6971 (COLO!, K!, LUBA!). NAMIBIA. Near Masari Experimental Farm, fl. 29 Jan. 1956, de Winter Eं Wiss 4467 (K!, M!, PRE, WIND!); near Ohopoho, fl. 1 April 1957, de Winter Eं Leistner 5297 (K!, M!, PRE!, WIND!); Caprivi, c. 39 miles from Katima on road to Linyanti, fl. 26 Dec. 1958, Killick E Leistner 3128 (K!, PRE!, WIND!); Guinas See, GR 455, fr. 24 April 1963, Giess et al. 6424 (M!, PRE!, WIND!); road Grootfontein - Maroelaboom, farm Neitsas 264, $90 \mathrm{~km}$ NE of Grootfontein, fl. 20 March 1968, H. $\mathcal{E} H$. E. Wanntorp 519 (K!, M!, PRE!, S); 17.5 km Kunene-abwärts von Swartbooisdrif am Bergaufstieg Zebraberge, fl. \& fr. 22 March 1974, Merxmüller E Giess 30497 (M!, PRE!, WAG!, WIND!); Rundu, outside township along the Okavango R., fr. 20 April 1977, Müller Eॄ Giess 413 (M!, PRE!, WIND!); about $3 \mathrm{~km} \mathrm{E}$ of Kremetartkop, fl. 27 Feb. 1986, Hines 637 (PRE, WIND!); Sonop Research Station, entrance to the Molopo camp, fl. 10 March 1997, Strohbach E' Sheuyange 3054 (WIND!); Oshikoto, along the main road from Farm Sachsenheim to Oshivelo, fr. 3 April 2002, Uiras MU540 (PRE!, WAG!, WIND!); Kaokoveld, tributary of the Otjiranga R., a few $\mathrm{km} \mathrm{N}$ of the Anglo-American geologist base camp, fl. 10 March 2003, Bartsch SB1306 (PRE!, WIND!); Rundu Distr., Yurn village, fl. 5 April 2006, Horn HOR2/282 (PRE!, WIND!); near Tsumeb, across the road from Farm Ghaub, fl. \& fr. 19 March 2010, Tripp E Dexter 786 (K!, RSA!, WIND!); Gelunksanker Farm on D3001, c. 10 km E of D3001 and B1 junction, fl. \& fr. 21 March 2010, Tripp $\mathcal{E}^{\circ}$ Dexter 811 (K!, RSA!, WIND!); Tsumeb Distr., on the D3001 road, few $\mathrm{km}$ from the main road B1, fl. 17 April 2015, Nanyeni et al. 1049 (K!, WIND!).

HABITAT \& ECOLOGY. This species occurs in dry woodland and bushland, typically with Acacia (Vachellia and/or Senegalia), Colophospermum mopane and/or Terminalia spp. on sandy soils, in dry riparian habitats and on rocky hillslopes. In Angola, it is also recorded from dry steppes with scattered shrubs and from fire-prone wooded grassland. It can grow in partial shade or in full sun, at (50 -) $200-1550 \mathrm{~m}$ elevation. In Namibia, it is found in the following vegetation types of Mendelsohn et al. (2002): the Western Highlands and Karstveld sub-divisions of the Acacia Tree-and-shrub Savanna, North-eastern Kalahari Woodland, Northern Kalahari, Eastern Drainage and Caprivi Mopane Woodland sub-divisions of the Broadleaved Tree-and-shrub Savanna.

CONSERVATION STATUS. This is a widespread and locally common species in a variety of dry woodland and bushland habitats, with an EOO of over 2,000,000 $\mathrm{km}^{2}$. It was assessed as of Least Concern - LC by Darbyshire (2015). It is locally abundant and widespread within the current study region and does not appear to be threatened.

NOTES. Barleria mackenii is fairly uniform over most of its broad range across southern Africa, but becomes considerably more variable in its western extremities, particularly in Angola. It is quite possible that more than one taxon is involved here, but from the limited Angolan material seen to date it has not been possible to delimit discrete taxa as the morphological characters seem to vary independently of one another. However, some of the variants are worthy of note; some of this variation is also exemplified in Fig. 5. The form separated as Barleria cunenensis by Benoist (1950) was first described from the Angolan side of the Namibian border at Ruacana but is also recorded in northwest Namibia (e.g. Hochobes MH1448; Kolberg et al. HK1507). These plants have a short fine patent indumentum on the leaves and calyces in addition to the longer, (sub)appressed hairs along the main veins; they also tend to dry a paler green than elsewhere in the range of $B$. mackenii where the plants often dry green-brown or darkly so. However, there are many intermediate specimens in northern Namibia with varying degrees of density of the indumentum and the variation appears to be clinal.

Elsewhere in Angola, typical Barleria mackenii, with hairy fruits $18.5-21.5 \mathrm{~mm}$ and calyces with hairs restricted to the veins and margin, only extends into Cuando Cubango Province in the extreme southeast (Harris $\mathcal{E}$ Turray-Hudson 822). In the Huíla region of the southwest, populations have glabrous or very sparsely hairy capsules that are on average slightly smaller, 15.5$20 \mathrm{~mm}$ long (e.g. Bamps et al. 4031, 4490). This form includes Benoist's (1950) B. jucunda var. pilosula and probably also his B. jucunda sensu stricto (both illegitimate names), although no ovaries or fruits are available for inspection on the type of the latter. Further north, from Benguela northwards through Cuanza Sul to Luanda Province, the plants become more variable, where small, slender forms with narrow lanceolate leaves and paler flowers occur (e.g. Bozeira et al. 10880; Cardoso de Matos 188) but these plants are variable in the density of the capsule and calyx indumentum. Further material is needed from Angola to resolve the taxonomy.

45. Barleria grootbergensis I.Darbysh. Eं E.Tripp (in Darbyshire et al. 2012: 760); Klaassen \& Kwembeya (2013: 129). Type: Namibia, W of Grootberg Pass, fl. 22 March 2010, Tripp E Dexter 828 (holotype RSA!; isotypes K! [K001290358], NY! [NY01239649], WIND! [WIND000094996]).

Shrub or perennial herb 30 - $100 \mathrm{~cm}$ tall; mature stems densely white-velutinous, hairs minute, declinate, interspersed with occasional longer appressed hairs; distal internodes patent glandular-pubescent and with sparser white declinate and appressed hairs. Leaves on petiole 4 - $16 \mathrm{~mm}$ long; blade somewhat coriaceous, ovate (-elliptic) or lanceolate, $3.5-8 \times 1.4-3.3 \mathrm{~cm}$, base cuneate, attenuate or obtuse, apex acute, attenuate or rarely obtuse, lateral veins $4-5$ pairs; leaf buds densely white-strigulose but mature leaves soon-glabrescent except for sparse strigose hairs along the margin, midrib and 
sometimes lateral veins beneath, some hairs "anvilshaped" (i.e. biramous with one long arm and one short arm), distal pairs of leaves also glandular-pubescent at least along margin. Inflorescences terminal spikes $2-8 \mathrm{~cm}$ long, often many-flowered and dense throughout or rarely becoming more lax towards base, each cyme within spike single-flowered or cymes at base of spike 3-flowered; bracts, bracteoles and calyces yellow-green to green or bracts sometimes drying darker green-brown; bracts in distal portion of inflorescence held \pm erect and (partially) covering the calyces, elliptic or somewhat oblanceolate, rarely lanceolate, $11.5-22 \times(3-) 4-8.5 \mathrm{~mm}$, apex acute or somewhat attenuate, pairs of bracts towards base of inflorescence often larger and more spreading, typically $21-33 \times 5-15 \mathrm{~mm}$, densely glandular-pubescent throughout; cymes often sessile but lowermost pairs can be pedunculate for up to $3.5(-6.5) \mathrm{mm}$ long; bracteoles held \pm erect against the calyx, narrowly elliptic, oblanceolate or lanceolate, $15.5-20 \times 2.5-5 \mathrm{~mm}$, apex acute, midrib or sometimes 3 main veins prominent; flowers subsessile. Calyx not markedly accrescent, anterior lobe elliptic or subrhombic, $11-19 \times 5.5-9 \mathrm{~mm}$, base cuneate or attenuate, apex acute or shallowly notched for up to 2.5 $\mathrm{mm}$, surface with $5-7$ prominent subparallel veins; posterior lobe as anterior lobe but marginally larger, apex acute or shortly attenuate, densely glandular-pubescent; lateral lobes lanceolate, 7 - 13.5 mm long. Corolla pink, blue or pale purple with whitish throat and tube, 34 $52 \mathrm{~mm}$ long, lateral lobes with numerous to sparse mixed glandular and eglandular hairs externally; tube 17 $28 \mathrm{~mm}$ long, subcylindrical or throat gradually expanded, mouth 3.5 - 6.5 ( - 7.5) mm wide; lobes in " $4+1$ " configuration, abaxial lobe offset by $5-9 \mathrm{~mm}$ from the remaining lobes, broadly obovate, $11-18.5 \times 7.5-14.5$ $\mathrm{mm}$, apex emarginate; lateral lobes elliptic-obovate or obovate, $11-18.5 \times 8-14 \mathrm{~mm}$, apices rounded or shallowly emarginate; adaxial lobes narrower, 4.5 $9.5 \mathrm{~mm}$ wide. Stamens inserted c. $7 \mathrm{~mm}$ from base of corolla tube; filaments $\pm 31 \mathrm{~mm}$ long; anthers $3.3-$ 4.3 (- 4.8) $\mathrm{mm}$ long; lateral staminodes to $1.5 \mathrm{~mm}$ long, flattened and triangular. Ovary densely glandularand eglandular-puberulous distally; style glabrous; stigma 1.5 - $3 \mathrm{~mm}$ long, curved. Capsule 2-seeded, 14 $18 \mathrm{~mm}$ long including beak $5-7 \mathrm{~mm}$ long, glandularand eglandular-puberulous; seeds $5.7-6.2 \times 5.4-5.8$ mm. Fig. 6G $-\mathrm{H}$.

DISTRIBUTION. Endemic to Northwest Namibia (Kunene Region); Map 7.

ADDITIONAL COLLECTIONS STUDIED. NAMIBIA. Kaokoveld, Orupembe, fl. 6 May 1951, Hall 321 (PRE!, SRGH!, WIND!); Sanitatas, fl. \& fr. 11 June 1963, Giess $\mathcal{E}^{2}$ Leippert 7533 (WIND!); Sanitatas - Kaoko Otavi, 6 miles from Sanitatas, fl. \& fr. 11 June 1963, Kers 1424 (WIND!); Farm OU 719, berge etwa 8 meilen $\mathrm{N}$ des Huab-Riviers, fl. 14 April 1964, Giess $\mathcal{E}^{\circ}$ Barnard 7951 (M!, PRE!, WIND!); Outjo Distr., 6 miles N of Huab R., road to Torra Bay, fl. 14 April 1964, Nordenstam 3722 (LD, M!); Farm Otjihavera: OU 703, fl. \& fr. 20 April 1964, Giess E Barnard 8133 (M!, PRE!, WIND!); Outjo Distr., 2 miles E of Farm Otjihavera (703), fl. \& fr. 20 April 1964, Nordenstam 3836 (LD, M!); Outjo Distr., Farm Humor, mountain pass, fl. \& fr. 20 April 1964, Nordenstam 3849 (LD, M!); Farm Bergsig (OU 714), am S-Berghang, fl. 30 March 1974, Merxmüller Eं Giess 30616 (M!, PRE, WIND!); Farm Krone: OU 721, between Gaias and Huab R., old infl. 17 June 1976, P. Craven E D. Craven 222 (WIND!); S of Kunene along road running $\mathrm{E}-\mathrm{W}$ joining the Hartmann and Marienfluss valleys, fl. \& fr. 21 May 1991, Smook 7742 (PRE!, WIND!); S of Kunene, $25.2 \mathrm{~km} \mathrm{~S}$ of Rooidrom on road to Orupembe, fl. \& fr. 24 May 1991, Smook 7789 (PRE!, WIND!); $2.5 \mathrm{~km} \mathrm{~S}$ of Arikana borehole, Springbok R., fl. 11 May 1998, Loutit 241 (WIND!); Kunene, "all areas", fl. \& fr. 4 June 1999, Hearn 6 (WIND!) \& idem, fr. 9 June 1999, Hearn 46 (WIND!); Aub Valley in the Aub R., fl. \& fr. 1 June 2000, Gindrig $\mathcal{E}$ Hennig 98 (PRE!, WIND!); N of Barab, fl. 3 April 2004, Burke 4087 (WIND!); Opuwo Distr., $12 \mathrm{~km}$ SE of junction of Springbokwater - Palmwag road, fl. 23 May 2008, Kolberg E Tholkes 2575 (WIND!); between Palmwag and Huab, fl. \& fr. 11 May 2001, Basson Bas 1/29/ 01 (WIND!); on C40, just W of Grootberg Pass in the Grootberg Mts, old infl. 18 Aug. 2011, Tripp $\mathcal{E}^{\circ}$ Dexter 1963 (K!, RSA!, WIND!); Khorixas Distr., Palmwag to Sesfontein road, fl. 15 May 2014, Nanyeni et al. 852 (K!, WIND!).

HABITAT \& ECOLOGY. Barleria grootbergensis is typically found growing on dry rocky hillslopes and along dry riverbeds, usually in open situations but occasionally in shade of Colophospermum mopane. It occurs at $950-$ $1550 \mathrm{~m}$ elevation. It is a species of the Kaokoveld Centre of plant endemism (sensu van Wyk \& Smith 2001) and is largely restricted to the North-western Escarpment and Inselbergs sub-division of the Nama Karoo vegetation type of Mendelsohn et al. (2002).

CONSERVATION STATUS. This species was assessed as Data Deficient in the protologue, when only two collections were known. However, it is now known to be considerably more widespread in the Kaokoveld region with an EOO of $12,300 \mathrm{~km}^{2}$. It occupies dry rocky slopes and riverbeds in arid areas, where human populations and impacts are low. Grazing pressure in some parts of its range may impact seedling recruitment, but this is not considered to be a major threat at present. This species is therefore reassessed here as of Least Concern - LC.

NOTES. A review of the Barleria material held at WIND, $\mathrm{M}$ and PRE has revealed this species to be more common and widespread than indicated in the protologue. The description is updated accordingly. Much of the material was filed under either 

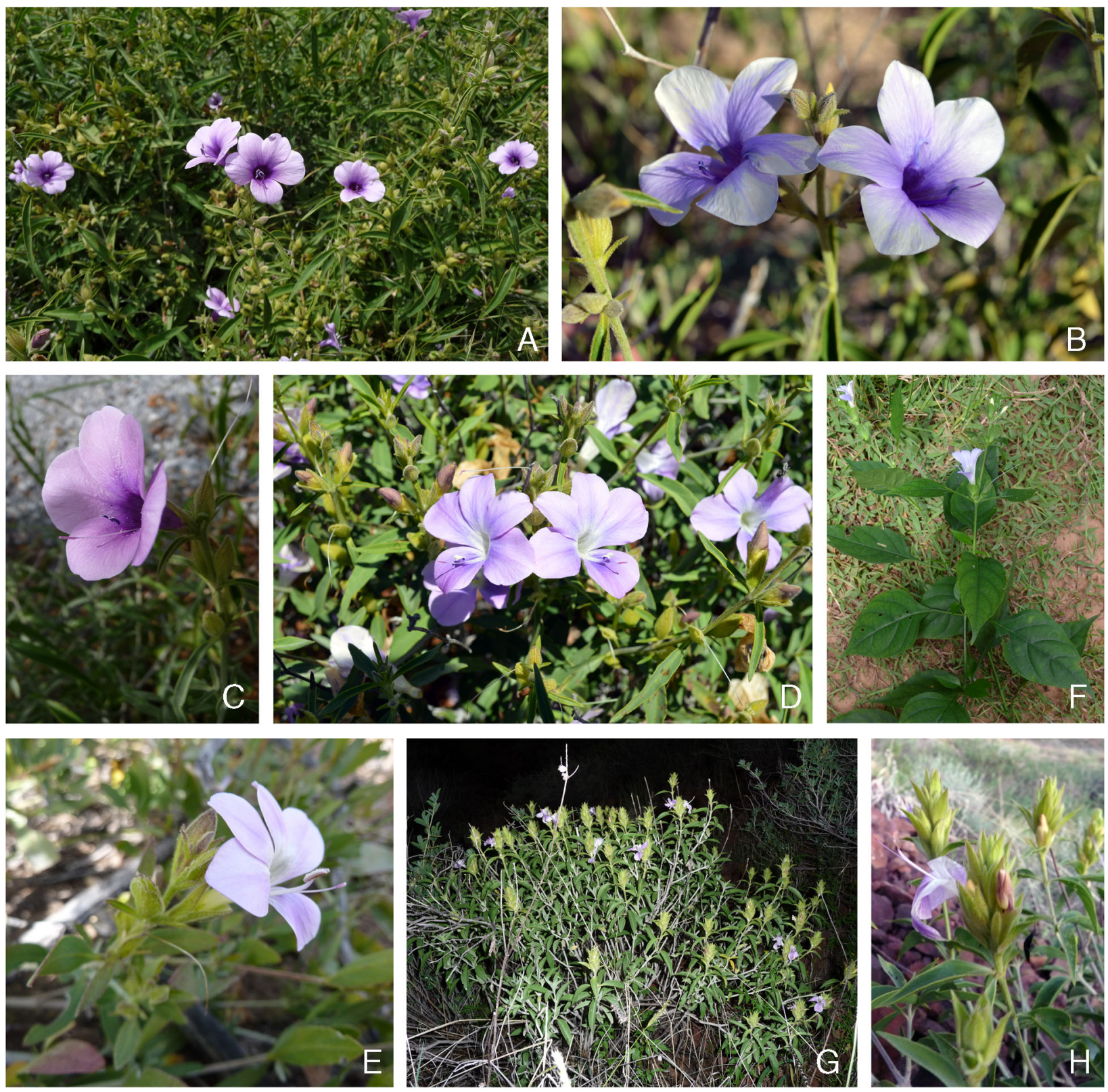

Fig. 6. A - E Barleria lancifolia. A - C habit and flowers, dark-throated form; D habit and flowers, pale-throated form; E trailing form from NW Namibia with semi-succulent leaves. F Barleria alata, habit and flowers, cut specimen. G - H Barleria grootbergensis. G habit; H inflorescences. A, C collected as Tripp \& Dexter 781; E as Tripp et al. 4798; G, H as Tripp \& Dexter 828. A - E, G, H Namibia, F Angola. PHOTOS: A, C, E, G, H E. A. MANZITTO-TRIPP; B, D I. DARBYSHIRE; F B. DITSCH.

B. lancifolia or, more surprisingly, under B. mackenii, although many collections were labelled as a potential new species near $B$. lancifolia by MandyJane Balkwill (Cadman). Whilst B. grootbergensis is clearly closely allied to $B$. lancifolia, the welldefined, \pm dense terminal spikes with erect bracts and bracteoles partially enclosing the calyces at least in the distal half of the spike, and the more acute, often subrhombic calyces are all characteristic and make this species easy to separate. The glandular hairs on the inflorescence are also longer and often more dense. A few specimens of
B. grootbergensis with more lax spikes (Basson 1/29/ 01, Giess E Leippert 7533, Kers 1424, Smook 7789) could be more easily confused although these still have the other characteristic morphological traits of B. grootbergensis.

46. Barleria lancifolia T.Anderson (1863: 28); Moore (1902a: 407; 1907b: 230); Obermeyer (1933: 147), excl. B. alata; Meyer (1957: 381; 1968: 15), pro maj. parte; Compton (1976: 553); Balkwill \& Balkwill (1997: figs. 2H, 7D, 12M \& R); Craven (1999: 152); 


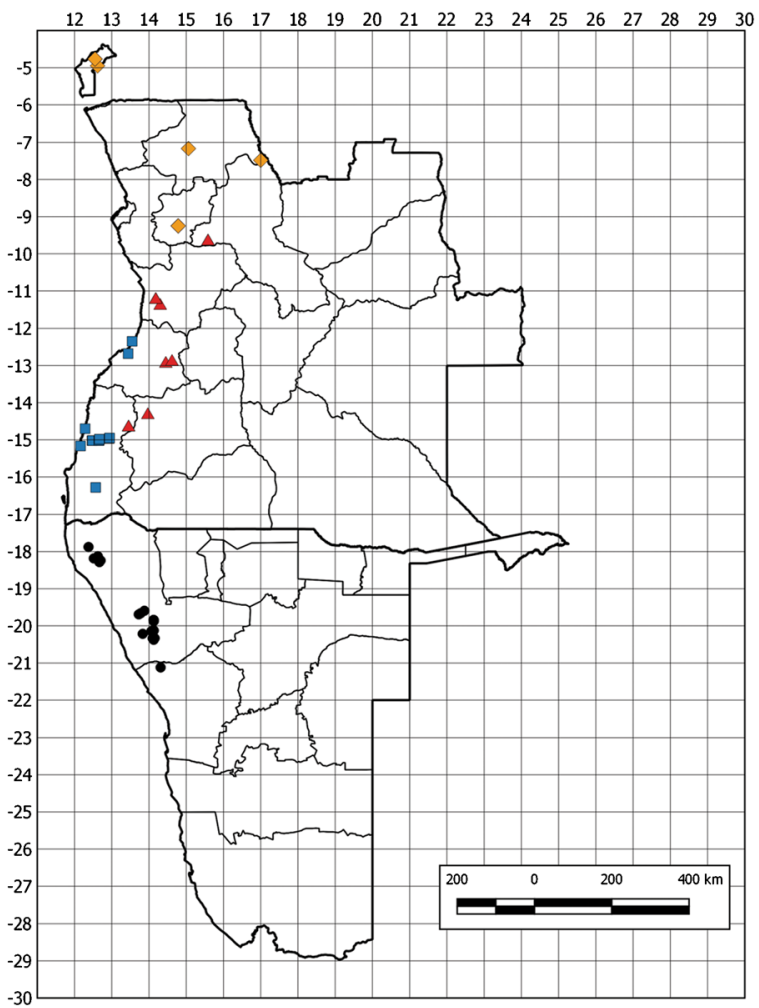

Map 7. Distribution of Barleria grootbergensis (black circles), B. gossweileri (blue squares), B. elliptica (red triangles) and B. alata (orange diamonds).

Welman (2003: 94); Klopper et al. (2006: 4); Darbyshire et al. (2012: 766); Klaassen \& Kwembeya (2013: 129); Darbyshire (2015: 101). Type: Namibia, Damaraland, herb. coll. Trin. Dublin s.n. (holotype TCD, n.v., missing).

Barleria hereroensis Engl. (Engler 1888: 261); Clarke (1899: 147). Type: Namibia, Hereroland, near Daviep, fl. \& fr. June 1886, Marloth 1460 (holotype $\mathrm{B}$, photo. at K; isotype PRE, n.v.).

Barleria latiloba Engl. (Engler 1888: 261). Type: Namibia, Hereroland, Otjimbingue, fl. \& fr. May 1886, Marloth 1316 (holotype $\mathrm{B} \dagger$, photo. at $\mathrm{K}$; isotypes GRA* [GRA0002735-0], SAM* [SAM0042846-0]).

Barleria cinereicaulis N.E.Br. ex C.B.Clarke (1901: 53). Types: South Africa, Natal, fl., without date, Gerrard 1266 (syntypes BM! [BM013400584], K! [K000394532]); Transvaal [Mpumalanga], Avoca, near Barberton, hillside above Sheba water-race, fl. 3 March 1894, Galpin 1331 (syntype PRE, n.v.).

Barleria rautanenii Schinz (1916: 437). Type: Namibia, Hereroland, Outjo, fl. July 1898, Rautanen 779 (holotype Z* [Z-000030571]).

Barleria alata sensu Clarke (1899: 158), pro parte, non S.Moore (1880: 266).

Perennial herb or usually a subshrub, 20 - $150 \mathrm{~cm}$ tall, woody towards base, branches varying from prostrate to erect; lower stems densely and minutely white- velutinous, uppermost internodes with \pm numerous patent glandular hairs and sparsely to densely puberulent, sometimes with scattered appressed-strigulose hairs. Leaf buds densely white-strigulose and/or -velutinous. Leaves on petiole to $15 \mathrm{~mm}$ long; blade lanceolate, narrowly elliptic or ovate, $1.8-11.5 \times 0.7-3.8 \mathrm{~cm}$ (l:w ratio $1.45-7.5: 1$ ), base attenuate or cuneate, apex acute or rarely obtuse, apiculate, surfaces soon glabrescent except margin and midrib beneath sparsely strigulose; lateral veins $4-5$ pairs. Inflorescences axillary in the distal portion of the branches, cymes 1 - 3-flowered, rarely with 2 cymes per axil, often together forming a lax spike; cymes sessile or peduncle to 10 (- 25) mm long; bracts foliaceous but often muchreduced at upper nodes, where typically linear or oblanceolate, $11-20 \times 2-5 \mathrm{~mm}$, often with scattered glandular hairs; bracteoles linear, oblanceolate or narrowly ellipticlanceolate, $6-20.5 \times 0.5-3.5 \mathrm{~mm}$, patent glandularpubescent, veins strigulose; flowers sessile or pedicels to $4.5 \mathrm{~mm}$ long. Calyx weakly accrescent; anterior and posterior lobes equal, elliptic to ovate-elliptic, $7-20 \times 4$ $-9.5 \mathrm{~mm}$ in flower, $12.5-25 \times 9.5-13.5 \mathrm{~mm}$ in fruit, base cuneate or acute, apex rounded to subattenuate or that of anterior lobe often minutely notched, external surfaces \pm densely patent glandular-pubescent or rarely these hairs sparse or absent, main veins strigulose, inner surface puberulous, venation palmate or subparallel, prominent; lateral lobes lanceolate, $5-9.5 \mathrm{~mm}$ long in flower, 9 - $13 \mathrm{~mm}$ in fruit. Corolla 26.5 - $48 \mathrm{~mm}$ long, blue, mauve or lilac with paler tube, mouth either darker purple or white, whole flower rarely whitish at anthesis, lateral lobes eglandular- and glandularpubescent externally, elsewhere glabrous; tube infundibuliform to narrowly so or almost cylindrical throughout, 13 - $18.5 \mathrm{~mm}$ long, basal cylindrical portion $3.5-4.5 \mathrm{~mm}$ wide, then rapidly to gradually widening to $4-12 \mathrm{~mm}$ at the throat; limb in " $4+1$ " configuration; abaxial lobe offset by $3.5-7 \mathrm{~mm}$, obovate, $12-18.5 \times 7.5-15 \mathrm{~mm}$, apex emarginate or rounded; lateral lobes obovate to elliptic $10-16 \times 7.5-$ $14 \mathrm{~mm}$, apices obtuse to emarginate; adaxial lobes as lateral lobes but $6-10 \mathrm{~mm}$ wide. Stamens attached $4-$ $5 \mathrm{~mm}$ from base of corolla; filaments $16.5-25 \mathrm{~mm}$ long; anthers 3-4.5 mm long; lateral staminodes $0.7-1.3 \mathrm{~mm}$ long. Ovary densely eglandular- and glandularpuberulous in distal half; style glabrous; stigma 1.5 $2.5 \mathrm{~mm}$ long. Capsule 2-seeded, 14 - $17.5 \mathrm{~mm}$ long, eglandular- and glandular-puberulous mainly on beak or sometimes with only antrorse-eglandular hairs; seeds \pm $6.5 \times 5 \mathrm{~mm}$. Fig $6 \mathrm{~A}-\mathrm{E}$.

DISTRIBUtION. Namibia (Erongo, Hardap, Karas, Khomas, Kunene, Omaheke, Omusati, Oshana, Oshikoto and Otjozondjupa Regions); widespread in southern Africa, occurring in Botswana, Zimbabwe, Mozambique, Eswatini and South Africa (Limpopo, North-West, Gauteng, Mpumalanga, KwaZulu-Natal \& Northern Cape Provs.); Map 8. 


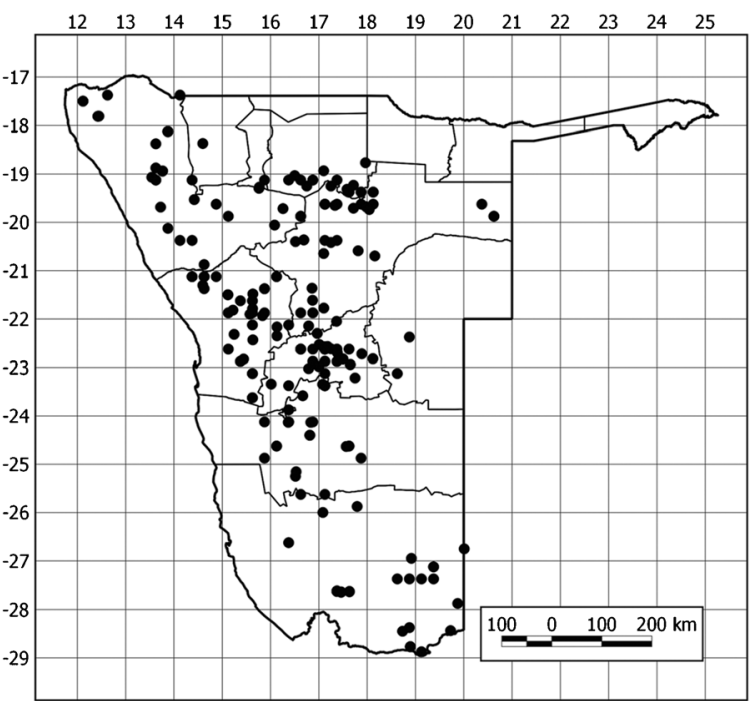

Map 8. Distribution of Barleria lancifolia.

SELECTED COLLECTIONS STUDIED. (Total of 216 Namibian collections seen). NAMIBIA. Okahandja, Wilhelmsberg, fl. \& fr. 25 March 1906, Dinter 72 (B!, BM!, K!, PRE); Windhoek, on koppies at Avisdam, fl. \& fr. April 1949, Liebenberg 4490 (K!, PRE, WIND!); on Farm Neu Heusis, 34 miles W of Windhoek, fl. 3 March 1955, de Winter 2602 (K!, M!, PRE, WIND!); Farm Tweekoppies, 13.9 miles $\mathrm{S}$ of Otjiwarongo on road to Okahandja, fl. 15 March 1955, de Winter 2738 (K!, PRE); Hoba Farm, 20 miles W of Grootfontein, fl. 22 March 1955, de Winter 2880 (K!, M!, PRE, WIND!); Farm Aais, confluence of the Nossob, fl. \& fr. 10 Jan. 1958, Merxmüller E Giess 1089 (M!, PRE, WIND!); 55 miles from Maltahöhe to Ababis, fl. 11 March 1965, Tölken Eं Hardy 654 (K!, PRE, WIND!); Farm Otjitambi, fl. \& fr. 2 May 1972, Schmidt 221 (M!, WIND!); Tumasberg, Namib Desert Park, fl. \& fr. 16 May 1973, Giess 13559 (K!, M!, PRE, WIND!); Farm Grasvlakte GR 457, fl. 25 April 1978, Giess 15196 (K!, M!, PRE, WIND!); Mara - Cloete's kloof, area of Hunsberg, above waterfall, fl. 11 July 1986, Craven 2656 (WIND!); $32 \mathrm{~km}$ from Otavi on Outjo road, fl. 5 March 1990, Hardy 7125 (PRE, WIND!); Etosha, fl. 25 April 2001, Curtis BC2146 (WIND!); Farm Narubis Noord, fl. \& fr. 4 July 2003, Schubert SS230 (WIND!); Kombat, between Otavi and Grootfontein, fl. \& fr. 19 March 2010, Tripp E Dexter 781 (K!, RSA!, WIND!); on C40 between Sesfontein and Opuwo, fl. 23 March 2010, Tripp Eं Dexter 837 (K!, RSA!, WIND!); $107.8 \mathrm{~km} \mathrm{~S}$ of Opuwo en route to Sesfontein on C43, boundary of Nabes Conservancy, fl. 26 March 2010, Tripp E Dexter 857 (K!, RSA!, WIND!); on D1930 between Uis and intersection with D1931, fl. 29 March 2010, Tripp E Dexter 886 (K!, RSA!, WIND!); $130 \mathrm{~km} \mathrm{~S}$ of Otjiwarongo on highway $\mathrm{B} 1,4.1 \mathrm{~km} \mathrm{~S}$ of intersection with D2112, fl. 17 Aug. 2011, Tripp Ẽ Dexter
1949 (K!, RSA!, WIND!); Hobasen Montana Restaurant \& Lodge, c. $5 \mathrm{~km} \mathrm{~S}$ of Rehoboth on B1, fr. 25 Aug. 2011, Tripp E Dexter 2025 (K!, RSA!, WIND!); Opuwo Distr., $15 \mathrm{~km}$ before Sesfontein coming from Puros, fl. \& fr. 18 May 2014, Nanyeni et al. 872 (WIND!, K!).

HABITAT \& ECOLOGY. Barleria lancifolia is recorded in a wide range of habitats although it is most often associated with freely drained rocky ground including hillslopes and rocky deserts. Elsewhere, it occurs in open dry woodland and bushland (e.g. of Acacia [Vachellia and/or Senegalia] spp. or Colophospermum mopane), and along road verges where it is often abundant. It grows at $500-2000 \mathrm{~m}$ elevation. It occurs in a range of the vegetation types recognised by Mendelsohn et al. (2002), particularly in most of the sub-divisions of the Nama Karoo and the Acacia Treeand-shrub Savanna. It is largely absent only in the Namib Desert lowlands along the coast, the Succulent Karoo in the southwest and most of the Broadleaved Tree-and-shrub Savanna of the northeast.

CONSERVATION STATUS. This is the most commonly encountered Barleria species in Namibia, often being abundant in a range of habitats. It is also widely distributed and fairly common across southern tropical Africa, extending as far east as Southwest Mozambique, with an EOO of over 1,600,000 $\mathrm{km}^{2}$. Furthermore, it tends to grow in areas of low agricultural value, such as dry rocky slopes, and it is tolerant of some disturbance, often being common along roadsides. It is assessed as of Least Concern - LC.

NOTES. As this is the most widespread and abundant species of Barleria in Namibia, it is no surprise that considerable regional and population-level variation is observed. More than one taxon may be involved, but for the present time we treat it as a single variable species with notes on the most distinctive forms.

Plants from southern Karas Region (e.g. Pearson 4022, K!; Craven 2656, WIND!) and extending into the Northern Cape of South Africa (e.g. Leistner 1351, K!) are dwarf shrublets to $50 \mathrm{~cm}$ tall with small ovate or narrowly ovate leaves to $3.2 \mathrm{~cm}$ long and with $1: w$ ratio $1.45-2.3: 1$. The inflorescence units are always singleflowered and the calyx lobes are often only sparsely glandular-pubescent at maturity, the glandular hairs sometimes restricted to the margins. Similarly broadleaved specimens are occasional from elsewhere in Namibia, particularly in the vicinity of Swakopmund, such as Jensen 207 (WIND!) from Tinkasrivier.

Further north in Karas Region is a second very distinctive form (e.g. de Winter 3418, K!, M!, PRE!, WIND!; Lensing A183/75, WIND!), in which the calyces are large, (12 -) 15 - $20 \mathrm{~mm}$ long, extending up to $25 \mathrm{~mm}$ long in fruit, and only sparsely hairy externally with few strigulose hairs along the veins and with glandular hairs either absent or (mainly) restricted to the margins. These plants 
also differ from the southern Karas plants in having more lanceolate leaves (l:w ratio (2.1 -) 2.5 - 3.2: 1), larger and deeper-coloured corollas (28 -) 33.5 - $50 \mathrm{~mm}$ long with a broader throat, and in having only sparsely pubescent capsules, the hairs antrorse-eglandular. A very few specimens from elsewhere in the species' range have sparse or largely absent glandular hairs on the calyx, such as Giess et al. 6245 (M!, WIND!) from Brandberg in Erongo Region.

In the Central Highlands of Namibia, particularly common around Windhoek, the corollas have a purple throat, deeper in colour than the lobes, and the corolla tube is markedly funnel-shaped (e.g. Ellinger ELLI/32, Kolberg HK717, both WIND!). Further north into Kunene and Otjozondjupa, the corollas usually have a white throat and the tube is typically less strongly funnel-shaped to almost cylindrical throughout (e.g. Schmidt 221, M!, WIND!).

A form from northern Namibia, associated with mopane woodland and areas of exposed calcrete (e.g. Giess 15179, WIND!; Tripp et al. 4798, COLO!, K!) is distinctive in having prostrate or sometimes weakly scrambling stems and more succulent leaves than typical (E. A. Manzitto-Tripp, pers. obs.; Fig. 6E) - it is otherwise similar to other pale-throated forms from northern Namibia. This form is known from few collections, mainly from the Tsumeb-Grootfontein area of Oshikoto but also around Opuwo in Kunene. It warrants further investigation.

47. Barleria gossweileri S.Moore (1911: 305; 1930: 134); Klopper et al. (2006: 4). Type: Angola, Lengue, fl. \& fr. Aug. 1910, Gossweiler 4948 (holotype BM! [BM000931095]; isotype K! [K000394502]).

Barleria exellii Benoist (1950: 19). Type: Angola, Montemor, km 74 from Moçâmedes, fl. 20 May 1937, Exell E̊ Mendonça 2127 (lectotype BM! [BM001015786], selected here; isolectotype $\mathrm{P}^{*}$ [P00434405]).

Barleria lancifolia sensu auctt., non T.Anderson (1863: 28): Makholela (2008: 22); Darbyshire (2015: 101), pro parte.

Subshrub, $30-150 \mathrm{~cm}$ tall; mature stems densely covered in a mix of appressed stiff white or creamcoloured hairs, these often biramous (medifixed or anvil-shaped), and minute deflexed white hairs in varying proportion, together giving the stem a whitegrey velutinous appearance; these two hair types becoming sparser on young stems where they are intermixed with \pm numerous short patent viscid glandular hairs with broad capitate heads; old stems woody with pale bark. Leaves sometimes absent when plants fertile; petiole $4-15 \mathrm{~mm}$ long; blade ovate, lanceolate or rarely elliptic, $2-8.5 \times 0.8-3.4 \mathrm{~cm}$ (l:w ratio $1.9-3.1: 1$ ), base attenuate or cuneate, apex acute, attenuate or rarely obtuse, surfaces at first with dense appressed biramous hairs of varying length but these caducous, mature leaves largely glabrous or often with few to numerous short patent glandular hairs beneath and along the margins; lateral veins $4-$ 6 pairs, rather inconspicuous. Inflorescences axillary but together often forming a loose paniculate or racemose thyrse, each cyme 1 or 3 (rarely 7)-flowered, \pm lax; bracts foliaceous but becoming progressively smaller and narrower up the stem; peduncle (2 -) $4.5-19 \mathrm{~mm}$ long, glandular- and eglandular-puberulous often also with appressed biramous hairs; bracteoles of first (central) flower in each cyme lanceolate to oblanceolate or linear, $(4.5-) 8.5-30 \times(0.5-) 1-7 \mathrm{~mm}$, often markedly curved, conduplicate, glandular-puberulous at least along margin, usually with biramous hairs at least along midrib, bracteoles of lateral flowers considerably smaller and linear; pedicel of first (central) flower in each cyme $(1-) 2-5.5 \mathrm{~mm}$ long. Calyx drying brown to pale green-brown, somewhat accrescent, anterior lobe elliptic or lanceolate, 10 $13.5 \times 3.3-6.2 \mathrm{~mm}$ in flower, up to $18 \times 7.5 \mathrm{~mm}$ in fruit, base cuneate, apex usually notched for $1-2.5$ $\mathrm{mm}$, more rarely acute or obtuse, external surface with numerous short patent glandular hairs and with appressed biramous (medifixed or often anvil-shaped) white hairs along main veins, internal surface densely glandular- and eglandular-puberulous, main veins subparallel, prominent especially in fruit; posterior lobe as anterior lobe but often more lanceolate, can be marginally longer, apex acute; lateral lobes linearlanceolate, $5.5-9 \mathrm{~mm}$ long in flower, up to $11 \mathrm{~mm}$ in fruit. Corolla white to pale blue or lilac, sometimes with purple markings in throat, $33-38 \mathrm{~mm}$ long, glabrous externally; tube 15 - $19 \mathrm{~mm}$ long, subcylindrical, throat only weakly and gradually expanded, mouth $3.5-5 \mathrm{~mm}$ wide; limb in " $4+1$ " configuration, abaxial lobe offset by $4.5-5.5 \mathrm{~mm}$, broadly obovate, $16.5-19$ $\times 11.5-15 \mathrm{~mm}$, apex emarginate; lateral lobes obovate-elliptic or broadly so, $13.5-16 \times 9.5-13.5$ $\mathrm{mm}$, apices emarginate; adaxial lobes as laterals but $7.5-10 \mathrm{~mm}$ wide. Stamens inserted $4-5.5 \mathrm{~mm}$ from base of corolla; filaments 26 - $29 \mathrm{~mm}$ long; anthers 3 $3.6 \mathrm{~mm}$ long; lateral staminodes $1-1.5 \mathrm{~mm}$ long. Ovary glandular- and eglandular-puberulous; style glabrous; stigma $1.6-2.4 \mathrm{~mm}$ long. Capsule 2-seeded, (13.5 -) 17 - $19.5 \mathrm{~mm}$ long including beak (3.5 -) 5.5 $6.5 \mathrm{~mm}$ long, glandular- and eglandular-puberulous; seeds $5-7 \times 4-5.5 \mathrm{~mm}$.

DISTRIBUTION. Southwest Angola (Benguela \& Namibe Provs.); Map 7.

ADditional COlLeCtions StUdied. ANGOlA. Near km 108.5 on Moçâmedes Railway, fl. 2 May 1909, Pearson 2075 (K!); near km 107 on the Moçâmedes Railway, fl. 28 May 1909, Pearson 2895 (K!); Moçâmedes, Muibi Bero, fl. 30 May 1937, Gossweiler 11003 (BM!, P*); 
Posto Experimental do Karakul [Caraculo], prox. R. Bero, fl. \& fr. July 1950, Gossweiler 14676 (BM!); environs do Lobito, fl. \& fr. Aug. 1937, Humbert 16065 (BM!); vallée du R. Mukungo et ses abords, N de Moçâmedes, old infl. Aug. 1937, Humbert 16417 (BM!, K!, P); Tschitundo-Lulo, sudlich des R. Cubal, fl. June 1954, Boss s.n. (M!); Dois Irmãos, Posto Experimental do Caraculo, fl. \& fr. 4 May 1960, Mendes 3924 (LUBA!); Caraculo, c. $20 \mathrm{~km}$ para Moçâmedes, fl. 7 May 1962, Santos 994 (BM!, LUBA!); a $19 \mathrm{~km}$ do Caracul, na margen de estrada para Moçâmedes, fl. \& fr. 19 May 1962, Figueira de Sousa 163 (LUBA!); Moçâmedes, Pediva, fl. \& fr. 1 June 1965, Henriques 488 (BM!, K!, LUBA!, PRE!, SRGH!); Caracul, Fundão, fl. 5 June 1967, Menezes et al. 2784 (LISC!, LUBA!); Caracul, Fundão, na picada para Opata, fl. \& fr. 7 June 1967, Menezes et al. 2837 (LISC!, PRE!).

HABITAT \& ECOLOGY. Barleria gossweileri is recorded in the hyper-arid Namib Desert region of southwest Angola, occurring on dry rocky hillslopes, desert peneplains with scattered trees and shrubs and from shaded dry thickets at $20-450$ m elevation.

CONSERVATION STATUS. This species has a restricted range in the desert lowlands of coastal southwest Angola. It extends from Iona National Park in the south through to Lobito in the north and has an EOO of $18,894 \mathrm{~km}^{2}$. The majority of the known localities are from the routes between Moçâmedes [formerly Namibe] and Lubango, these being the most well surveyed of this underbotanised region (see Tripp \& Darbyshire 2020), and it is likely to be more common within its range than the current data indicate. The locality from the environs of Lobito (from where it was recorded in 1937) may have been impacted by expansion of this port city. However, the large majority of its range has a low human population and its habitat is not favourable to agriculture, hence human pressures are considered to be low and this species is unlikely to be threatened by direct human impact. It is therefore currently assessed as of Least Concern - LC. That said, in the longer term, there is a plausible threat from climate change and increasing aridity in the Namib Desert which may result in longer spells of drought, although the likely impact on this species is not known.

NOTES. In the protologue, Moore (1911) noted "the habit is much that of B. alata S. Moore belonging to Sect. Eu-Barleria. It is quite unlike the other known species in Sect. Somalia" (p. 305). Therefore, he did not link this species with Barleria lancifolia. However it has more recently been treated as a variant of B. lancifolia (including by the current first author; Darbyshire 2015) and it is certainly close to that species, but it is resurrected here in view of the fact that is has unique characters of biramous (medifixed or anvil-shaped) hairs on the young leaves, stems, bracteoles and calyces and a glabrous corolla. Barleria gossweileri is often fertile when leafless and has consistently lax inflorescences, the latter character easily separating this species from the related B. grootbergensis. The rank at which it should be recognised is open to debate, but we choose to treat it as a distinct species at present, pending further studies on this group (see introductory note to the B. lancifolia-B. mackenii complex).

This species has a comparable range to several other species of Acanthaceae that are restricted to the Angolan extension of the Namib Desert, including Barleria deserticola I.Darbysh. \& E.Tripp (see Discussion).

48. Barleria elliptica Benoist (1950: 16). Type: Angola, Cuanza Sul, Vila Nova do Seles [Seles], fl. \& fr. 12 July 1937, Exell $\mathcal{E}$ Mendonça 3180 (lectotype BM! [BM001015785], selected here).

Barleria alata S.Moore var. amoena Benoist (1950: 17). Type: Angola, Moçâmedes, Humbia, Chela Mt, fl. 20 May 1937, Gossweiler 10960 (lectotype BM! [BM001014868], selected here; isolectotypes COI* [COI 00094197 ], K! [ K0 00394512 ], P* [P00434401]), synon. nov.

Barleria alata S.Moore (1880: 266; 1902a: 407), pro parte \& sensu Clarke (1899: 158), pro parte, quoad Welwitsch 5194 \& 5195 - see note to Barleria alata.

Barleria lancifolia sensu auctt., non T.Anderson (1863: 28): Hiern (1900: 816), pro parte \& Heine (1966: 164 , in notes), pro parte, quoad Welwitsch 5194 \& 5195 .

Perennial herb or subshrub, 40 - $90 \mathrm{~cm}$ tall [fide Teixeira $\mathcal{E}$ Andrade 7340, but likely to reach greater height], stems usually puberulent with mixed minute colourless eglandular and glandular hairs throughout or restricted to basal portions, or these hairs rarely largely absent, distal internodes sometimes largely glabrous except for sparse yellow strigulose hairs or pale spreading hispid hairs, often also with scattered short patent glandular hairs. Leaves on petiole 3 $32 \mathrm{~mm}$ long or rarely subsessile; blade elliptic or lanceolate, sometimes becoming obovate upwards, largest leaves $(5-) 8-15 \times 2-5.5 \mathrm{~cm}$ (1:w ratio $2-$ 4.8: 1), base attenuate and with a \pm pronounced narrow cuneate extension decurrent onto petiole, apex attenuate or distalmost leaves acute to obtuse; leaf buds densely strigose and puberulent, mature leaves sparsely strigose or hispid along margin, main veins beneath and scattered on adaxial surface, or glabrescent; lateral veins $4-6$ pairs. Inflorescences 1 - 3flowered cymes in upper axils, often widely spaced, sessile or cymes at lower fertile nodes pedunculate for up to 12 (-30) $\mathrm{mm}$; bracts foliaceous but reducing and narrowing upwards, those at uppermost nodes typically narrowly elliptic, oblanceolate or linear, 12 - 
$36 \times 2-11 \mathrm{~mm}$; bracteoles linear, then $4-10 \times 0.3-2$ $\mathrm{mm}$, or those of lowermost inflorescences sometimes oblanceolate and up to $11-19 \times 2.5-5 \mathrm{~mm}$; flowers sessile or pedicels to $3 \mathrm{~mm}$ long. Calyx with anterior and posterior lobes subequal, green or brownish, elliptic to lanceolate, $11-18 \times 4.5-7.5 \mathrm{~mm}$, base cuneate to obtuse, apex acute to rounded or that of anterior lobe shallowly notched, surfaces strigulose to hispidulous along main veins and margin, elsewhere shortly glandular-pubescent and usually also eglandular-puberulent, up to 8 subparallel veins prominent or only 2 on anterior lobe and 1 on posterior lobe prominent; lateral lobes pale, linearlanceolate, 5 - $8.5 \mathrm{~mm}$ long. Corolla 29 - $47 \mathrm{~mm}$ long, pink, blue, pale purple or white, lateral lobes pubescent externally with mixed eglandular and glandular hairs; tube 15 - $21 \mathrm{~mm}$ long, widened above attachment point of stamens or barely so, $4.5-7 \mathrm{~mm}$ in diam. below mouth; limb in weak " $4+1$ " configuration, abaxial lobe offset by $2-3.5 \mathrm{~mm}$, obovate or broadly so, $13-21.5 \times(7-) 10.5-15.5 \mathrm{~mm}$, apex rounded; lateral lobes obovate to broadly so, $15-24.5 \times 7-14.5$ $\mathrm{mm}$; adaxial lobes oblong-obovate, $6-10.5 \mathrm{~mm}$ wide. Stamens inserted in lower third of corolla tube; filaments 20 - $31 \mathrm{~mm}$ long; anthers $3-5 \mathrm{~mm}$ long; lateral staminodes minute, triangular, $\pm 0.5 \mathrm{~mm}$ long. Ovary densely puberulous with mixed eglandular and glandular hairs; style glabrous; stigma linear, 1.2 - 2 (2.6) $\mathrm{mm}$ long. Capsule 2-seeded, 18.5 - $22 \mathrm{~mm}$ long including beak $6-7 \mathrm{~mm}$ long, indumentum as ovary; seeds $5.5-6 \times 5-5.5 \mathrm{~mm}$.

DISTRIBUtION. West Angola (Benguela, Cuanza Sul, Huíla, Malanje and Namibe Provs.), Southwest D. R. Congo; Map 7.

AdDitional COllections Studied. ANGola. Pungo Andongo, fl. May 1857, Welwitsch 5194 (BM!, K!, LISU!); Pungo Andongo, near Barrancos de Catete, fl. May 1857, Welwitsch 5195 (BM!, K!, LISU!); Cuanza-Sul, Seles (Ucu), nr. R. Cambongo (Gunza) \& R. Quéve (Cuvo), fl. 15 Sept. 1930, Gossweiler 9363 (BM!, K!, US!); idem, fl. Oct. 1930, Gossweiler 9374 (BM!, K!, US!); Moçâmedes, Humbia, Chela Mt, fl. 20 May 1937, Gossweiler 10960 (BM!, K!); Benguela, Capacca (Membassoco), fl. April 1941, Faulkner A.403 (BM!, K!, PRE!); Lukundu [Lucondo], fl. June 1954, Boss s.n. (M!); Benguela, C. E. Ganda, na base do serra do Posto, fl. 6 June 1963, Teixeira Ẽ Andrade 7340 (LUBA!); Moçâmedes, encosta da Serra da Chela, fl. \& fr. 29 May 1965, Mendes dos Santos 1464 (LUBA!, PRE!). D. R.

CONGO. Kasai, Suka (Kwango), fl. \& fr. July 1975, Dujardin 421 (BR!).

HABITAT \& ECOLOGY. Very little habitat information is available for Barleria elliptica, but it has been recorded from xerophytic bushland and from open rocky ground. In the single collection from D. R. Congo it was recorded from gallery forest. It occurs at c. $1000-$ 1700 m elevation.
CONSERVATION STATUS. This species has a scattered distribution in western Angola and just extends over the border into southern D. R. Congo, with an EOO of $58,250 \mathrm{~km}^{2}$. From the evidence to date, it appears to be scarce with highly isolated subpopulations, but this may be a product of incomplete botanical inventory over much of its range. As the specific habitat requirements for this species are currently unclear, it is difficult to assess the threats with certainty. Some of the known historical localities have been impacted by human activities; for example, the area of Capacca near Cubal is intensively farmed except for the steep slopes of the large inselberg to the north of the Cubal - Ganda road, and the Pungo Andongo area has suffered from recent (post-2000) loss of "forest cover" (Mendelsohn 2019, Fig. 8.1). However, if, as some evidence indicates, this species favours rocky ground then the impact from agriculture may be reduced. In view of this uncertainty, it is assessed as Data Deficient - DD but it may prove to be of Least Concern.

NOTES. Despite the obvious morphological similarities, Benoist (1950) did not equate his Barleria alata var. amoena with his own B. elliptica published in the same paper. The former has markedly narrow lanceolate leaves (l:w ratio $3-4.8: 1$ ) and narrow lanceolate outer calyx lobes (l:w ratio $2.5-3.5$ : 1 ), often with only two veins prominent on the anterior lobe and one vein on the posterior lobe. In most other populations of B. elliptica, the leaves are elliptic or somewhat obovate (l:w ratio $2-2.6: 1$ ) and the outer calyx lobes are elliptic or ovate-elliptic (1:w ratio $2-2.35$ : 1 ), with up to 8 subparallel veins prominent. However, Faulkner A.403 and Dujardin 421 are somewhat intermediate between the two forms. Moreover, the type of B. elliptica is also somewhat intermediate: it has the narrow leaves (ratio 3.5: 1) of var. amoena but elliptic calyces (ratio 2.3 - 2.5: 1) with several nerves prominent. The two forms are therefore considered to be the extremes of a clinal variation and $B$. alata var. amoena is synonymised here.

Gossweiler's specimens from Seles (Gossweiler 9363 and 9374) differ from the other material seen in having a spreading-hispidulous indumentum on the stems and leaves; the type of Barleria elliptica from the same area has sparse ascending long stem hairs.

This species is morphologically close to Barleria lancifolia but differs in lacking the dense white puberulous stem indumentum (puberulous hairs, if present, are colourless in B. alata) and in having typically larger leaves with a pronounced attenuate wing-like base. See also the Notes under B. alata for further discussion on this complex.

49. Barleria alata S.Moore (1880: 266), pro parte - see note; Clarke (1899: 158), pro parte quoad Welwitsch 5147, 5148 \& 5169; Moore (1902a: 407), pro parte; 
Moore (1930: 135), pro parte quoad Gossweiler 6531; Benoist (1950: 17), pro parte excl. var. amoena; Heine (1966: 162, pl. 33: 1 - 8); Sosef (2006: 36). Type: Angola, Golungo Alto, Queta, fl. \& fr. June 1856, Welwitsch 5148 (lectotype BM! [BM000537168], selected here, isolectotypes LISU! [LISU223403, LISU223406]). Additional syntypes: Golungo Alto, Queta fl. June 1856, Welwitsch 5147 (BM! [BM000537173], LISU! [LISU223404]) \& idem, fr. July 1856, Welwitsch 5169 (BM! [BM000537169], LISU! [LISU223407]). [Syntypes rejected $(=B$. elliptica): Pungo Andongo, fl. May 1857, Welwitsch 5194 (BM! [BM0 00537174], K! [K000394513], LISU! [LISU223409]); Pungo Andongo, near Barrancos de Catete, fl. May 1857, Welwitsch 5195 (BM! [BM000537163], K! [K000394514], LISU! [LISU223408]) — see note].

Barleria lancifolia sensu auctt., non T.Anderson (1863: 28):

Hiern (1900: 816), pro parte quoad Welwitsch 5147, 5148 \& 5169; Welman (2003: 94), pro parte; Klopper et al. (2006: 4), pro parte.

Perennial herb or subshrub, $30-80 \mathrm{~cm}$ tall, branches often procumbent or decumbent and rooting at the lower nodes, sometimes straggling; stems drying green-black, uppermost internodes sometimes with short retrorse eglandular hairs and patent glandular hairs on two opposite sides, mature stems soon glabrescent. Leaves with unwinged portion of petiole (7 -) 20 - $70 \mathrm{~mm}$ long; blade thinly papery, ovate or ovate-elliptic, largest leaves $(6.5-) 8-16 \times 3-7.7 \mathrm{~cm}$, base with a pronounced narrow cuneate extension forming a wing along distal portion of petiole, then attenuate or more abruptly rounded, apex acuminate, surfaces largely glabrous or sparsely strigulose along margin, main veins beneath and scattered on adaxial surface; lateral veins (3-) $4-5$ pairs. Inflorescences terminal, spiciform, (2 -) $4-23 \mathrm{~cm}$ long, at first contracted but cymose units soon becoming \pm widely spaced along rachis, each cyme 1 - 3-flowered, subsessile, those in lower portion of spike sometimes aborting early; rachis densely patent glandularpubescent and with retrorse eglandular hairs; bracts rapidly reducing and narrowing up the spike, those midway along rachis oblanceolate or narrowly elliptic, 7.5 - $16(-20) \times 2-5.5 \mathrm{~mm}$, sometimes caducous; bracteoles linear, then $3.5-10 \times 0.5-1 \mathrm{~mm}$, or those of lowermost cymes sometimes oblanceolate and up to $14 \times$ $3 \mathrm{~mm}$; pedicels $1-5(-7.5) \mathrm{mm}$ long. Calyx green with \pm paler base, somewhat accrescent, anterior and posterior lobes obovate, anterior lobe $7.5-13 \times 4-8 \mathrm{~mm}$ in flower, up to $18.5 \times 9.5 \mathrm{~mm}$ in fruit, base cuneate or attenuate, apex rounded or often notched for up to 2 $\mathrm{mm}$, posterior lobe slightly longer, apex rounded or obtuse, rarely subacute, external surfaces patent glandular- and eglandular-pubescent, glandular hairs sometimes mainly along margin, main veins subparallel,
4 or 6 on anterior lobe, usually 5 on posterior lobe, sometimes inconspicuous, sparsely strigulose; lateral lobes pale green, linear-lanceolate, $(4.5-) 6-8 \mathrm{~mm}$ long in flower, up to $12.5 \mathrm{~mm}$ in fruit. Corolla $26-47 \mathrm{~mm}$ long, lobes pale blue, mauve or lilac, tube and throat whitish, glabrous externally or lateral lobes glandular and/or eglandular pilose; tube 12.5 - $19 \mathrm{~mm}$ long, funnel-shaped above insertion point of stamens, 4.5 $9 \mathrm{~mm}$ in diam. below mouth; limb in " $4+1$ " configuration, abaxial lobe offset by $(2-) 3.5-8 \mathrm{~mm}$, oblong-elliptic or obovate, $(8-) 10-21 \times 8-12$ $\mathrm{mm}$, apex rounded; lateral lobes oblong-obovate, $10-20 \times 6-9 \mathrm{~mm}$; adaxial lobes narrower, oblong-oblanceolate, $4-7.5 \mathrm{~mm}$ wide. Stamens inserted 5 - $7.5 \mathrm{~mm}$ from base of corolla tube; filaments 14 25 mm long; anthers (2.2 -) 2.7 - 4.2 mm long; lateral staminodes attenuate, $1-2.5 \mathrm{~mm}$ long. Ovary densely eglandular-puberulous with intermixed short-stalked glands; style glabrous; stigma linear, 1.1 - $1.6 \mathrm{~mm}$ long. Capsule 2-seeded, $14-20.5 \mathrm{~mm}$ long including beak 4 $5.5 \mathrm{~mm}$ long, eglandular- and glandular-puberulous; seeds $4-5.3 \times 3.5-5.2 \mathrm{~mm}$. Fig. $6 \mathrm{~F}$.

Distribution. North Angola (Cabinda, Cuanza Norte and Uíge Provs.); West-Central Africa: Cameroon, Central African Republic, Gabon, Congo (Brazzaville) and West D. R. Congo; Map 7.

AdDitional Collections Studied. ANGola. Cabinda, Buco Zau, fl. 27 July 1916, Gossweiler 6531 (BM!); $50 \mathrm{~km} \mathrm{~N}$ of Uíge, fl. \& fr. 19 Sept. 1958, Stanton 90 (BM!); Cabinda, Buco-Zau, Caio, fl. 22 June 1959, Jardim e Museu Agrícola Ultramar 496 (LISC!) \& idem, Monteiro Ẽ Murta 79 (LISC!, LUBA!); Uíge, Caruma, estrada da Cambimba, fl \& fr. 4 March 1972, Henriques 1482 (LISC!, LUAI!). CAMEROON. East Prov.: 15 km N of Bertoua, along road to Deng Deng, fl. \& fr. 15 March 1961, Breteler 1210 (K!, P!, PRE!, WAG); 17 km $\mathrm{N}$ of Bertoua, along road to Deng Deng, fl. 6 Jan. 1962, Breteler et al. 2414 (EA!, K!, P!, PRE!, WAG). CENTRAL AFRICAN REPUBLIC. Boukoko, fl. 4 Jan. 1949, Equipe in Tisserant 1313 (BM!, P!); Région de Mbaïi et Boukoko, fl., without date, Tisserant s.n. (P!). CONGO (BRAZZAVILLE). Région du Niari, ?Lomba à Bononga, fl. June 1888, Thollon 1050 (P!); entre le bac et les chutes de la Bouenza sur la route Mouyondzi Sibiti, fl. \& fr. 23 Aug. 1965, Farron 4563 (P!); Ile M'Bamou, partie de Moutou ya N'Gombé, fl. 10 May 1967, Sita 1591 (P!); Ile M'Bamou, environs de Moutou ya N'Gombé, fl. 20 May 1968, Sita 2136 (P!). D. R. Congo. Kasaï, (?)Kingundi, fl. \& fr. 20 June 1911, Vanderyst s.n. (BR!); Lamba, fl. \& fr. 19 Aug. 1911, Reding 33 (BR!); Dumu, fl. \& fr. July 1914, Vanderyst 4840 (BR!); Bokala, fl. Aug. 1914, Vanderyst 4980 (BM!, BR!); Mayombe, Temvo, fl. 25 Feb. 1919, Vermoesen 1651 (BR!) \& fl. \& fr. 18 March 1919, Vermoesen 1835 (BR!); entre Kasongo [Lunda] - Baringa, fl. 1925, 
Vanderyst 17523 (BR!) \& fl. \& fr. 1925, Vanderyst 17525A (BR!); Kasongo Lunda, fl. \& fr. 1925, Vanderyst 17538 (BR!); Gimbi, fl. \& fr. 6 March 1948, Laurent 292 (BR!); M'Vuazi - Forêt de Kimalongo, fr. 5 Sept. 1952, Devred 1227 (BR!, WAG); Luki, plateau du Poste, fl. 22 April 1953, Wagemans 506 (BR!); région de Kipako, fl. 14 July 1953, Callens 4153 (BR!, K!, WAG); territoire de Songololo, route de Kimpese à Songa, fl. \& fr. 16 June 1960, Compere 2154 (BR!); territoire Kasangulu, Zongo, fl. 2 July 1971, Halle 1933 (BR!). GABON. Ogooué-Lolo Prov., Région de Lastoursville, Mahounda, fl. \& fr. 30 July 1930, le Testu 8200 (BM!, K!, LISC!, P!).

HABITAT \& ECOLOGY. Barleria alata is a species of moist forest, particularly in clearings and along forest margins or in secondary forest, and has also been recorded from coffee plantations. It can also occur in periodically inundated swamp forests. It occurs at 100 - 800 m elevation.

CONSERVATION STATUS. This species is widespread in the Congolian forests of West-Central Africa, with an EOO of $765,372 \mathrm{~km}^{2}$ based upon known occurrence data. However, it appears to be rather scarce at least in parts of its range; for example, it is known from only one collection in Gabon and from only one locality in Cameroon. Forest remains widespread within parts of its range and it appears tolerant of or even to favour low-level habitat disturbance, although forest clearance in some parts of its range will almost certainly have led to some local subpopulation declines. In view of its large range, it is here assessed as of Least Concern - LC.

NOTES. Heine (1966) correctly concluded that the five syntypes of Barleria alata cited by Moore (1880) represent two distinct species. He was also right that the forest species he treated as B. alata sensu stricto for the Flore $d u$ Gabon is distinct from B. lancifolia, a species that Clarke (1899) had erroneously synonymised within B. alata sensu lato, contrary to the Botanical Code (Turland et al. 2018). However, Heine did not formally lectotypify $B$. alata, thus prolonging the nomenclatural confusion. Furthermore, in his long discussion on the status of $B$. alata we believe he made two errors. The first was to equate the Pungo Andongo syntypes (Welwitsch 5194 and 5195) with B. lancifolia when in fact they represent an allied but distinct species, B. elliptica (see above). The second was to state that Moore's protologue description was based primarily on Welwitsch 5147, 5148 and 5169, when in fact there are several characters, including the stem indumentum and shape of the calyx lobes, that Moore clearly derived from Welwitsch 5194 and 5195. The original description of B. alata is therefore an amalgamation of the two taxa represented by the five syntypes and it is clear from later literature (Moore 1902a, 1930) that Moore continued to consider the syntypes and subsequent collections of these taxa to represent a single species. On examining the BM material of B. alata in November 1933, Amelia Obermeyer ("AAO 8/11/33") annotated Gossweiler 6531 with "Not!" adjacent to the original determination of Barleria alata S.Moore, adding "prob. n. sp.". "Not" is also written in the same handwriting next to "Barleria alata S.Moore" at the foot of each of the three syntypes Welwitsch 5147, 5148 and 5169. By inference, Obermeyer must have considered Welwitsch 5194 and 5195 to represent true $B$. alata, although her basis for this decision is unclear. It is perhaps because Welwitsch 5195 is the largest of the five syntype specimens at BM and is annotated with a full Latin description, transcribed from Welwitsch's notes. This specimen is the only one to have been subsequently curated in a type cover, but this does not mean that it should automatically be chosen as the lectotype. We have chosen instead to lectotypify B. alata using Welwitsch 5148. This has been done to promote nomenclatural stability, in view of Heine's (1966) application of the name $B$. alata and in view of the fact that the second species, represented by Welwitsch 5194 and 5195, already has a name: B. elliptica Benoist. Furthermore, the name $B$. alata best suits the species represented well by Welwitsch 5148 in view of its wing-like leaf base.

Barleria alata differs from B. elliptica in the mature stems being glabrous (vs usually puberulent); the leaves having longer petioles and more markedly rounded leaf base above the decurrent wing; the terminal spiciform thyrse being better developed with more rapidly reduced bracts upwards; the outer calyx lobes being obovate, (vs elliptic or lanceolate) with longer hairs (pubescent vs puberulous); and the corolla having a more strongly offset abaxial lobe.

The two specimens seen from Cameroon differ somewhat from the rest of the material in having relatively short corolla lobes (the ratio of tube: abaxial lobe being 1.8: 1 in Breteler 1210, this being $0.8-1.35$ : 1 in other material), more densely hairy lateral corolla lobes, smaller anthers and more conspicuously pedicellate fruits. The collection seen from C.A.R. probably matches this form but the corollas are in bud only. These three collections are rather disjunct from the rest of the species' distribution, and further material from these two countries is desirable to determine whether this should be treated as a distinct taxon.

50. Barleria kacondensis S.Moore (1911: 306; 1930: 135); Klopper et al. (2006: 4); Makholela (2008: 21). Type: Angola, near Kaconda [Caconda], fl. Feb. 1907, Gossweiler 4251 (lectotype BM! [BM000931092], selected here). Additional syntypes: Angola, Forte D. Maria Pia, Dongo, fl., without date, Gossweiler 2909 (BM! [BM000931093], K! [K000545559]); near Munongue Velho [Menongue], fr. 22 April 1906, Gossweiler 4147 (BM! [BM001124103], K! [K000545560]). 
Suffruticose herb, with several erect branches from a small woody rootstock, sometimes shortly rhizomatous with numerous fleshy roots; main stems $30-80 \mathrm{~cm}$ tall, these unbranched or with several to many divergent lateral branches, stems patent- to retrorsepubescent throughout or restricted to two opposite lines. Leaves sessile or petiole to $6 \mathrm{~mm}$ long; blade somewhat coriaceous, most cauline leaves lanceolate to narrowly so or oblong-elliptic, $5.3-13.2 \times 0.7-$ $3.6 \mathrm{~cm}$ (l:w ratio $3.3-8.4: 1$ ), base cuneate or abruptly obtuse, margin entire, apex acute-apiculate, midrib beneath patent-pubescent, margin with shorter ascending hairs, these sometimes also sparse on upper surface, or surfaces glabrescent; lateral veins $6-9$ pairs but often not well differentiated from the prominent reticulate tertiary venation; leaves towards base of stems sometimes obovate with apices more rounded. Inflorescences axillary towards apex of main and lateral branches, sometimes aggregated into short spikes, each cyme single-flowered or lowermost cyme rarely 3-flowered; bracts foliaceous but reducing upwards, those towards stem apices typically oblongelliptic to -lanceolate or linear-lanceolate, $22-41 \times 3.5$ - $12 \mathrm{~mm}$; cymes sessile or peduncle to $6 \mathrm{~mm}$ long, or cymes at lowermost fertile axils with peduncle up to 30 - $90 \mathrm{~mm}$ long; bracteoles of most flowers linearlanceolate, oblanceolate or narrowly elliptic, $10.5-23$ $\times 1.5-6 \mathrm{~mm}$, erect or ascending, often conduplicate, pubescent at least on margin and midrib, bracteoles of long-pedunculate flower at lowermost fertile axils can be more spreading and narrowly oblong-elliptic to lanceolate, $30-55 \times 6-12 \mathrm{~mm}$; pedicels absent or to $3 \mathrm{~mm}$ long or those of lowermost flowers to $4.5 \mathrm{~mm}$ long, puberulous. Calyx in dry state green or often dark brown or purple-tinged, somewhat accrescent; anterior lobe ovate or elliptic, (15.5-) $18.5-27 \times 9-$ $16 \mathrm{~mm}$ in flower, up to $30 \times 18 \mathrm{~mm}$ in fruit, base rounded to acute, margin entire, often involute, apex sometimes attenuate, narrowly notched for $0.5-4 \mathrm{~mm}$ or emarginate, external surface pale-pubescent at least along the palmate main veins and margin or glabrescent; posterior lobe as anterior lobe but (16 -) $21-30.5 \times 9.5-17 \mathrm{~mm}$ in flower, up to $35 \times 23 \mathrm{~mm}$ in fruit, apex acute, attenuate or rarely obtuse, margin can be markedly involute; lateral lobes straw-coloured, linear-lanceolate, (7.5 -) 10 - 15.5 mm long. Corolla 33 - $52 \mathrm{~mm}$ long, white, cream or pale pink, glabrous externally; tube 13.5 - $19 \mathrm{~mm}$ long, cylindrical below insertion point of stamens where $3.5-5 \mathrm{~mm}$ in diam., markedly funnel-shaped above, mouth $6.5-10.5 \mathrm{~mm}$ in diam.; limb in " $4+1$ " configuration or weakly so, abaxial lobe offset by $1.5-6.5 \mathrm{~mm}$, this and lateral lobes broadly obovate, $18.5-30.5 \times 17-23.5 \mathrm{~mm}$, apices emarginate; adaxial lobes somewhat narrower, $17-26.5 \times 12-20 \mathrm{~mm}$. Stamens inserted c. $5-8.5 \mathrm{~mm}$ from base of corolla tube; filaments $12.5-16.5 \mathrm{~mm}$ long, with subsessile glands throughout or in proximal $2 / 3$, glandular-pubescent to -villose at base; anthers 3.9 - $5.3 \mathrm{~mm}$ long, shortly exserted; lateral staminodes 1.2 - $2.8 \mathrm{~mm}$ long. Pistil glabrous; stigma linear, 2.5 $3.8 \mathrm{~mm}$ long, curved. Capsule 4-seeded, $19-22.5 \mathrm{~mm}$ long with beak $4-5 \mathrm{~mm}$ long, glabrous; immature seeds $5.5-8.5 \times 4.5-6 \mathrm{~mm}$. Figs $7 \mathrm{~A}-\mathrm{D}, 8$.

\section{0a. Barleria kacondensis S.Moore subsp. kacondensis}

Plants conspicuously hairy throughout, particularly on the stems, abaxial surface of the leaves and on the calyx lobes, hairs persistent; stems usually muchbranched. Fig. 7A - D.

DISTRIBUTION. Endemic to Southern Angola (Bié, Cuando Cubango and Huíla Provs.); Map 4.

AdDitionAl COlLections StUdied. ANGolA. Caconda, fl. March 1882, d'Anchieta 24 (BM!); Menongue, Serpa Pinto [Menongue], fl. bud April 1906, Gossweiler 4147 (LISC! - see note); without precise locality, old infl., 1954 - 1955, Boss s.n. (M!); Menongue, andados c. $127 \mathrm{~km}$ de Caiundo para Vila Serpa Pinto [Menongue], fl. 4 Feb. 1960, Mendes 2379 (K!, LISC!); Menongue, andados $10 \mathrm{~km}$ de Vila Serpa Pinto [Menongue] para Caiundo, fl. 17 Feb. 1960, Mendes 2654 (K!, LISC!); entre Caconda e Matala, fr. 21 June 1965, Correia 2989 (LUBA!); Pereira d'Eça [Ondjiva] - Artur Paiva [Kuvango], km 266, fl. 9 March 1973, Bamps et al. 4100 (BR, LISC!, WAG!); near Cuchi R., $85 \mathrm{~km}$ W of Menongue, fl. 16 March 2016, Goyder 8493 (K!, LUBA, PRE!); Caconda, Cusse, near Catchipuepue village, fl. 2017, F. M. P. Gonçalves sight record (photo.!).

HABITAT \& ECOLOGY. Subsp. kacondensis grows in open miombo (Brachystegia and Julbernardia) woodland and wooded grassland including amongst rock outcrops, at c. $1300-1650 \mathrm{~m}$ elevation.

CONSERVATION StATUS. Subsp. kacondensis has a restricted range in southern Angola, with an EOO of $20,492 \mathrm{~km}^{2}$ based on known occurrence data. Most of the records are from the vicinity of the type locality at Caconda and from the vicinity of Menongue. It is not known to occur in any protected areas, and its range coincides with areas that have experienced some of the most extensive losses of "forest cover" in Angola between 2000 and 2015 (Mendelsohn 2019, fig. 8,1), particularly in the vicinity of Menongue and in the western part of its range. As this species prefers open grassland and wooded grassland, it may be able to tolerate some woodland clearance, but as most of this woodland loss has been through conversion to agricultural land, the population of this species is highly likely to be in decline. Based on current evidence, it is known from fewer than 10 locations with a continuing decline in quality and extent of habitat but its range 

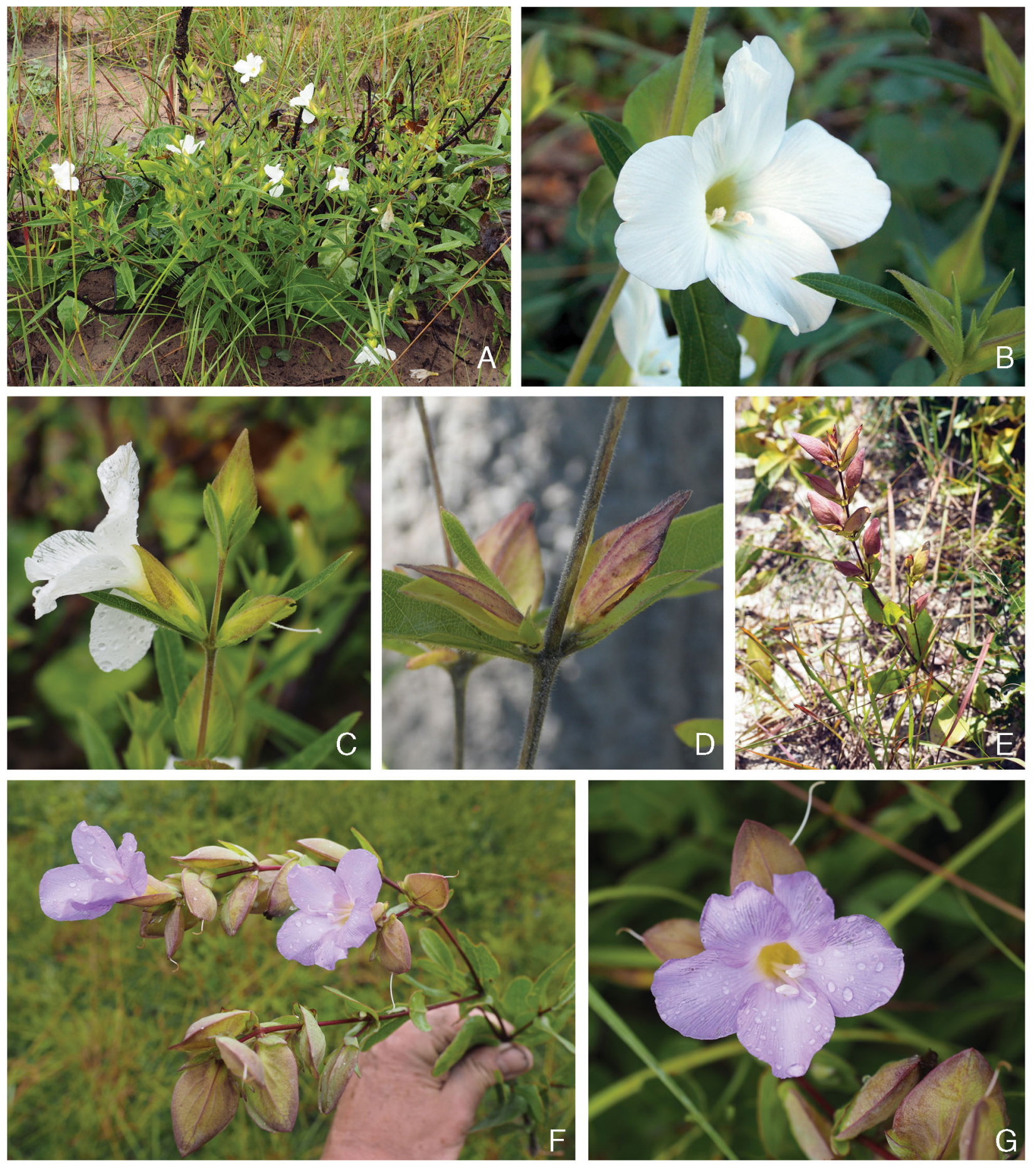

Fig. 7. A - D Barleria kacondensis subsp. kacondensis. A habit; B flower; C inflorescence; D detail of inflorescence node. E - G Barleria thunbergiiflora. E habit, fruiting; F habit, flowering; G flower. A, C collected as Goyder 8493, E as Goyder 8952, F, G as Goyder 8343. PHOTOS: A, C, E - G D. J. GOYDER; B, D F. M. P. GONÇALVES (ALL IMAGES ANGOLA).

falls just outside the threshold for Vulnerable under criterion B1 of IUCN (2012). It is therefore assessed as Near Threatened - NT B1ab(iii).

NOTES. The BM sheet of Gossweiler 4251 is selected as the lectotype, as it is an informative specimen and was cited by Moore (1911) as being used for the basis of the calyx measurements in the protologue. The LISC sheet of Gossweiler 4147, which is annotated by Spencer Moore, bears a different collecting locality name to the syntype at BM under the same collecting number, although the two localities are essentially the same. Further, the LISC sheet is in flower bud only whereas 
both the $\mathrm{BM}$ and $\mathrm{K}$ sheets (the latter of which has no locality information on the label) are in fruit; the LISC sheet is therefore not considered to be an isosyntype.

This subspecies could potentially be mistaken for pale-flowered forms of Barleria mackenii (see species 44 above) as they share broad, ovate calyces with hairy palmate venation and large corollas with a broadly funnel-shaped tube. However, B. kacondensis is easily separated from that species by the suffruticose habit, coarser stem indumentum, glabrous corolla, glandular staminal filaments and glabrous, 4-seeded fruits.

50b. Barleria kacondensis S.Moore subsp. glabrescens I.Darbysh. subsp. nov. Type: Angola, Huambo, estrada de Nova Lisboa [Huambo] para Luanda, Serra do Cussava (encosta a sul), fl. 26 Dec. 1970, Moreno 314 (holotype BM! [BM001010576]; isotype M! [M0224573]).

http:/ /www.ipni.org/urn:lsid:ipni.org:names:77215731-1

Barleria benguellensis sensu Benoist (1950: 18), pro parte quoad Exell Ẽ Mendonça 1906, non S.Moore (1911: 305).

Plants sparsely and inconspicuously hairy or glabrescent; stems unbranched or few-branched. Fig. 8.

RECOGNITION. Subsp. glabrescens differs from subsp. kacondensis primarily in being less densely and conspicuously hairy particularly on the stems and calyces, with the hairs less persistent such that the fruiting plants are glabrescent, but it also differs in the stems arising from the woody rootstock being fewer branched, and in the apex of the posterior calyx lobes being acute or obtuse, not attenuate as is frequent in subsp. kacondensis.

DISTRIBUTION. Endemic to West Angola (Huambo Prov.); Map 4.

ADDITIONAL COLLECTIONS STUDIED. ANGOLA. Between Nova Lisboa [Huambo] and Quipeio, fr. 11 May 1937, Exell E Mendonça 1906 (BM!); Huambo, estrada de Nova Lisboa [Huambo] para Luanda, Serra do Cussava (encosta a sul), fl. 26 Dec. 1970, Moreno 312 (BM!, M!).

HABITAT \& ECOLOGY. This subspecies is recorded from xerophytic bushland and on rock outcrops in wooded grassland at c. $1500-1700 \mathrm{~m}$ elevation.

CONSERVATION STATUS. Subsp. glabrescens is so far known from only two locations, c. $30 \mathrm{~km}$ apart in central Huambo Province. It was recorded as locally abundant at Serra do Cussava in 1970 by Moreno. However, satellite imagery available on Google Earth shows that this area is now heavily cultivated, particularly along the main roads leading north and northwest from Huambo. Mendelsohn (2019) notes the extensive loss of "forest cover" in Huambo, much of which occurred between the 1950s and 1970s when it was cleared for croplands. More recently, Palacios et al. (2015) report high rates of miombo woodland loss in Huambo, reducing from $78.4 \%$ province-wide in 2002 to only $48.3 \%$ in 2015 , with much of the reduction attributable to further expansion of croplands. Whilst the impacts of this rapid agricultural expansion may be reduced on this subspecies in view of its apparent preference for rock outcrops and xerophytic communities that are less favourable for agriculture, the sheer scale of habitat transformation in central Huambo is highly likely to have had a negative impact. It is therefore tentatively assessed as Endangered - EN B2ab(iii), but with more information on distribution, abundance and threats highly desirable. ETYMOLOGY. The epithet "glabrescens" denotes the fact that this subspecies is separated from subsp. kacondensis by its glabrescence at maturity.

NOTES. This distinctive allopatric subspecies is perhaps worthy of full species status but the differences from Barleria kacondensis sensu stricto are mainly vegetative. In all three specimens seen, the lowermost cymes are longpedunculate and with the first (or only) flower subtended by an enlarged, foliaceous pair of spreading bracteoles. This character is only rarely seen in subsp. kacondensis, where the cymes are usually subsessile or shortly pedunculate throughout the plant.

Benoist (1950) considered Exell Eै Mendonça 1906 to belong to Barleria benguellensis and indeed subsp. glabrescens could be confused with that species. However, it differs in several notable characters: (1) the staminal filaments are covered in subsessile glands throughout, in addition to being glandularpuberulous at the base, whilst only the latter is present in B. benguellensis; (2) its stems are erect whilst those of $B$. benguellensis appear to be trailing and \pm weakly decumbent; (3) the cymes are more widely spaced at least proximally and those at the lowermost fertile nodes are held on long peduncles; these are absent in $B$. benguellensis where the cymes are all subsessile and congested into a dense terminal spike; (4) the corolla lobes are considerably broader, the abaxial and lateral lobes being broadly obovate to obovate-orbicular in shape rather than oblong-elliptic to oblong-obovate in $B$. benguellensis. We also consider it very likely that $B$. benguellensis will have a 2-seeded capsule (as per its close allies $B$. polyneura and $B$. violascens) whereas in $B$. kacondensis the capsule is 4-seeded.

Moreno considered his numbers 312 and 314, growing side by side at the same locality, to be two different taxa. This was presumably because of the variation in flower colour from cream (312) to pale pink (314). There is also a slight difference in calyx shape, those on 312 being more ovate, but they clearly 


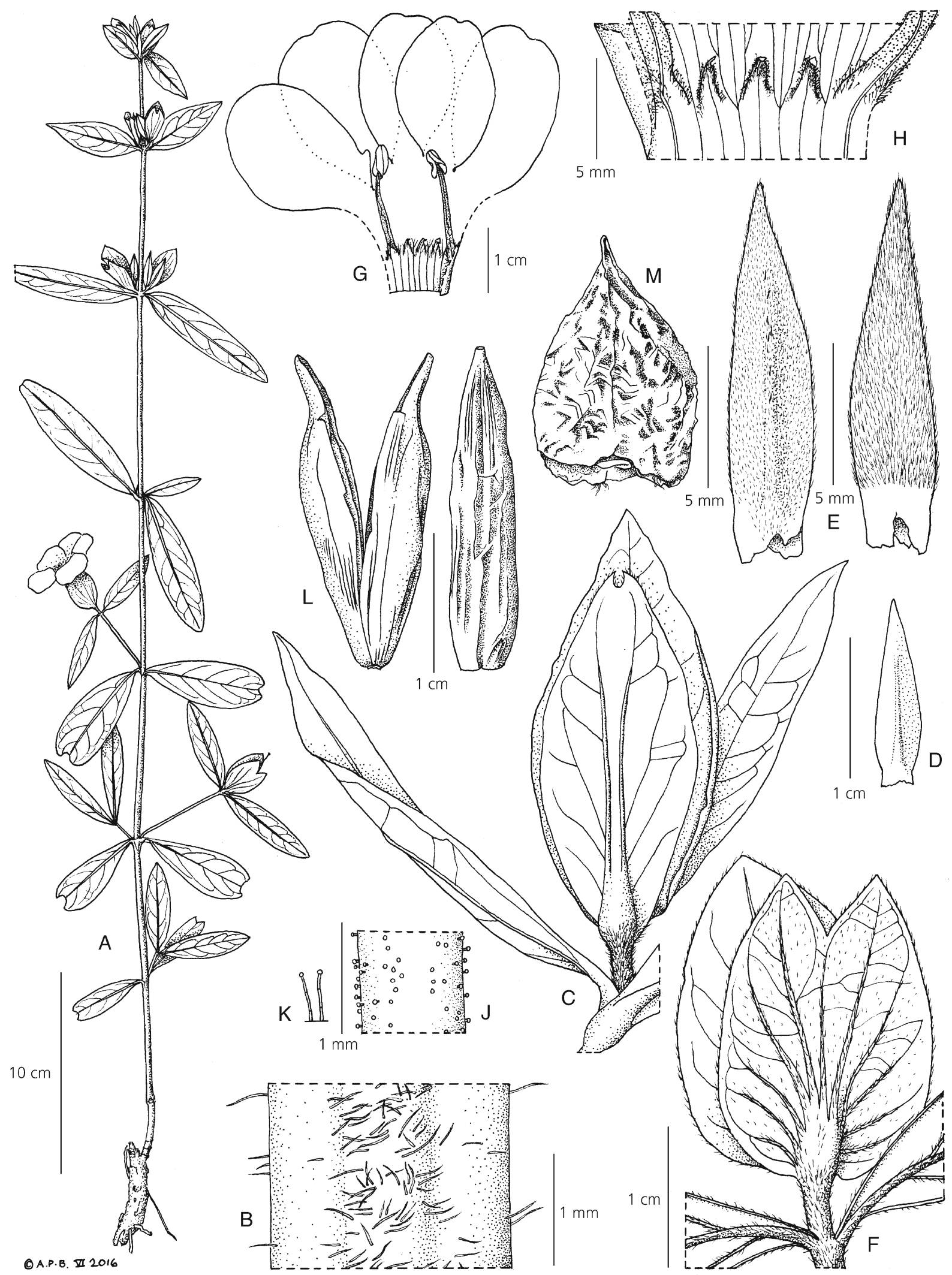

Fig. 8. Barleria kacondensis subsp. glabrescens. A habit; B detail of stem indumentum; C calyx and subtending bracteoles; D lateral calyx lobe; E detail of lateral calyx lobe showing external (left) and internal (right) indumentum; F calyx and proximal portion of bracteoles, variant from lowest fertile node; $\mathbf{G}$ dissected corolla with androecium; $\mathrm{H}$ detail of staminodes and staminal filament bases; J detail of glandular hairs on mid/ upper portion of staminal filaments; $\mathrm{K}$ detail of hairs from staminal filament base; L capsule, lateral view (left) and dorsal view (right); M seed. A, B, F - K from Moreno 312, C - E from Moreno 314; L, M from Exell \& Mendonça 1906. DRAWN BY ANDREW BROWN. 
belong to the same taxon. In subsp. kacondensis, the flowers are usually white.

51. Barleria thunbergiiflora I.Darbysh. sp. nov. Type: Angola, Moxico Prov., confluence of Cuito R. and Calua R., fl. 25 Feb. 2016, Goyder 8343 (holotype K! [K001333932]; isotypes INBAC, LUBA, PRE!).

http:/ /www.ipni.org/urn:lsid:ipni.org:names:77215732-1

Barleria benguellensis sensu Benoist (1950: 18), pro parte quoad Exell Ẽ Mendonça 1345, non S.Moore (1911: 305) — see note.

Suffruticose herb, with erect unbranched or fewbranched stems $30-50 \mathrm{~cm}$ tall from a woody base, this sometimes shortly rhizomatous, with numerous fleshy roots; stems 4-angular, with short white antrorse or appressed hairs concentrated in two opposite bands, or these sparse (possibly glabrescent on mature stems). Leaves sessile or petiole to $2 \mathrm{~mm}$ long; blade somewhat coriaceous, held erect or ascending, largest cauline leaves ovate, elliptic or obovate, $4.4-7.8 \times 2-$ $4.3 \mathrm{~cm}$ (1:w ratio $1.3-2.5: 1$ ), base cordate, rounded or obtuse to cuneate or attenuate, margin entire, apex obtuse to rounded, apiculate, surfaces glabrous or with few pale hairs along midrib beneath; lateral veins $4-8$ pairs, these and fine reticulate tertiary venation prominent on both surfaces. Inflorescences of opposite single-flowered cymes aggregated into loose spikes 5 $15 \mathrm{~cm}$ long; bracts foliaceous but rapidly reducing upwards, those towards stem apices ovate, oblongelliptic or somewhat -obovate, $12.5-30 \times 8-15 \mathrm{~mm}$, base shallowly cordate to cuneate; cymes at lowermost fertile axils on peduncle 9 - $19 \mathrm{~mm}$ long, peduncles shortening distally where $2.5-5 \mathrm{~mm}$ long; bracteoles \pm tightly conduplicate and clasping calyx base, ovate to lanceolate or elliptic to oblanceolate, $13.5-28 \times 5.5-$ $12 \mathrm{~mm}$, glabrous; pedicels $2-4 \mathrm{~mm}$ long, palepuberulous. Calyx pale yellowish green with reddish, purple or purple-brown tinge towards or along margins and/or in distal half, somewhat accrescent; anterior lobe broadly ovate, $23-27 \times 16.5-21 \mathrm{~mm}$ in flower, up to $31 \times 23.5 \mathrm{~mm}$ in fruit, base rounded to cordate, margin entire, often involute, apex very shallowly notched or obtuse to rounded, external surface glabrous, with prominent palmate venation, internal surface finely appressed-puberulous; posterior lobe as anterior lobe but $24.5-30 \times 17.5-21 \mathrm{~mm}$ in flower, up to $32.5 \times 26 \mathrm{~mm}$ in fruit, apex obtuse or rounded, apiculate; lateral lobes pale green, lanceolate-attenuate, 14 - 15 mm long, puberulous. Corolla 42 - $53 \mathrm{~mm}$ long, lilac-blue, glabrous externally; tube 17 $19 \mathrm{~mm}$ long, cylindrical below insertion point of stamens, markedly funnel-shaped above, mouth c. $12 \mathrm{~mm}$ in diam.; limb in " $4+1$ " configuration, abaxial lobe offset by $3.5-5.5 \mathrm{~mm}$, broadly obovate to obovate-orbicular, c. $21.5 \times 18.5 \mathrm{~mm}$, apex rounded or slightly emarginate, lateral lobes obovate-elliptic, 23 - $25.5 \times 18$ - $21 \mathrm{~mm}$, adaxial lobes somewhat narrower, $19.5-25 \times 16-18 \mathrm{~mm}$. Stamens inserted c. $7 \mathrm{~mm}$ from base of corolla tube; filaments 17 $18.5 \mathrm{~mm}$ long, with subsessile glands throughout and glandular-puberulous at base; anthers c. $5 \mathrm{~mm}$ long, shortly exserted; lateral staminodes $2-3 \mathrm{~mm}$ long. Pistil glabrous; stigma linear, 2.9 - $4.5 \mathrm{~mm}$ long, curved. Capsule 4-seeded, 23 - $24.5 \mathrm{~mm}$ long including beak $\pm 5 \mathrm{~mm}$ long, glabrous; seeds $\pm 7.5-8 \times 6.5 \mathrm{~mm}$. Figs $7 \mathrm{E}-\mathrm{G} \& 9$.

RECOGNITION. Barleria thunbergiiflora is most closely allied to B. kacondensis, with which it shares a large corolla with a broadly funnel-shaped tube and glandular staminal filaments. It differs in having ovate or elliptic to obovate leaves, with l:w ratio $1.3-2.5$ : 1 , held erect or ascending (vs leaves spreading, oblongelliptic to lanceolate, l:w ratio $3.3-8.4$ : 1 ), in the corolla being blue-lilac (vs white to pale pink) and in having broader calyces with a more broadly obtuse or rounded apex to the posterior lobe (vs usually acute or attenuate in B. kacondensis). It additionally differs from B. kacondensis subsp. kacondensis in being largely glabrous (vs coarsely hairy throughout) and in the plants being less widely branched. Vegetatively, this species most closely resembles $B$. eburnea but it is easily separated by the much larger, blue-lilac flowers $42-$ $53 \mathrm{~mm}$ long, with longer staminal filaments 17 $18.5 \mathrm{~mm}$ long that are glandular throughout (vs corolla white to pale yellow, $28-31 \mathrm{~mm}$ long, staminal filaments $6.5-8 \mathrm{~mm}$ long, glabrous except at the base in B. eburnea); B. eburnea also has narrower, subulate to oblancelate bracteoles that are markedly arcuate.

DISTRIBUTION. Endemic to Eastern Angola (Lunda Sul and Moxico Provs.); Map 4.

ADDITIONAL COLLECTION STUDIED. ANGOLA. Lunda Sul Prov., Biula, R. Cassai [Kasai], old infl. 28 April 1937, Exell Ẽ Mendonça 1345 (BM!, P*) - see note; Moxico Prov., upper Lungue Bungu river valley $77 \mathrm{~km}$ SE of Cuemba and $48 \mathrm{~km} \mathrm{~S}$ of Munhango, fr. 25 April 2018, Goyder 8952 (INBAC, K!, LUBA!, PRE!).

HABITAT \& ECOLOGY. Barleria thunbergiiflora occurs in open grassland rich in geoxylic suffrutices on deep Kalahari Sands on plateaux above rivers, and in seasonal marshes ("tengas") at 1190 - $1400 \mathrm{~m}$ alt. It appears to occur on more nutrient-poor sites than most of the allied species in sect. Somalia.

CONSERVATION STATUS. This species is currently known from three localities, two of which are in close proximity in western Moxico Province. The third locality is over $200 \mathrm{~km}$ to the northeast of the Moxico sites, in southern Lunda Sul Province. However, the area of Angola in which it occurs is one of the least well botanised regions of continental Africa (see Discussion) and its range is likely to be larger than 




Fig. 9. Barleria thunbergiiflora. A habit; $\bar{B}$ mature leaf, öbovate variant; $C$ leaf apex showing apiculum, adaxial surface; $D$ detail of reticulate leaf venation, abaxial surface; $\mathrm{E}$ indumentum of young stem; $\mathrm{F}$ detail of stem hairs; $\mathrm{G}$ calyx and subtending bracteoles; $\mathrm{H}$ lateral calyx lobe, (right) at same scale as calyx and bracteoles and (left) blown up to show indumentum; J flower, face view; K dissected corolla with androecium; L detail of staminodes and staminal filament bases; $\mathbf{M}$ detail of glandular hairs on mid/upper portion of staminal filaments; $\mathrm{N}$ hairs from staminode; $\mathbf{P}$ hairs from staminal filament base. A, C - J, K - P from Goyder 8343, B from Exell \& Mendonça 1345; J from photograph taken by D. Goyder. DRAWN BY ANDREW BROWN. 
currently known given the fact that its preferred habitats are widespread there. Of the two populations found by D. Goyder (pers. comm.), only a single patch of this species was found at the type locality, but at the second locality (his collection 8952) the population was much larger and scattered over several kilometres. The perched valley-grasslands on sand that this species occupies are nutrient-poor and are not suitable for agriculture, so there are no obvious threats. Increased frequency of burning, observed in some areas (D. Goyder, pers. obs.), may result in gradual ecological changes over time but the human population remains low within much of its range at present. It is therefore assessed as of Least Concern - LC.

ETYMOLOGY. The species epithet "thunbergiiflora" refers to the fact that the flowers of this species superficially resembles the genus Thunbergia in having large, funnel-shaped corollas and in the large calyx lobes resembling the conspicuous paired bracteoles in Thunbergia. Indeed, the type specimen of this plant was first identified as a Thunbergia in the field.

NOTES. Exell E Mendonça 1345 from the Kasai River along the Lunda Sul-Moxico provincial border is close to the other material of this species, although the leaves and bracts are obovate (but note that in Goyder 8952 some of the stems have equally obovate leaves) and the bracteoles are larger, less markedly conduplicate and more oblong or oblanceolate. This specimen only has old, empty calyces and it would be desirable to collect flowering material from that location to confirm that it belongs here.

The close relationship between Barleria thunbergiiflora and B. kacondensis, inferred from morphological evidence, has recently been confirmed by RADseq phylogenetic analysis (Comito 2019). The two species are readily separated by the characters given in the Recognition section; B. thunbergiiflora appears to replace B. kacondensis in the more nutrient-poor soils of eastern Angola.

52. Barleria sp. (= Teixeira s.n.).

Barleria ruellioides sensu Makholela (2008: 22), non

T.Anderson (1863: 30).

?Erect herb, mature stems stout, c. $5 \mathrm{~mm}$ in diam., subterete, drying brown, with two opposite lines of fine pale spreading hairs. Leaves subsessile, blade coriaceous, drying brown, ovate or ovate-elliptic, $11.5-14.3 \times 5.9-$ $6.5 \mathrm{~cm}$ (1:w ratio $\pm 2: 1$ ), base rounded or subcordate, margin entire, apex shortly attenuate, surfaces glabrous; lateral veins $5-7$ pairs, these and fine reticulate tertiary venation prominent beneath. Inflorescences of singleflowered cymes aggregated into dense \pm many-flowered terminal spikes $5-7 \mathrm{~cm}$ long, drying brown-green; bracts at base of spikes foliaceous, ovate or ovate-elliptic, typically $27-38 \times 15-19 \mathrm{~mm}$, rapidly reducing in size up the spike, those in the upper portion narrowly oblong-elliptic, typically $21-23 \times 4.5-6.5 \mathrm{~mm}$, glabrous; cymes subsessile; bracteoles held erect, linear-lanceolate to linear-oblanceolate, $20-26 \times 2.5-3.5 \mathrm{~mm}$ or those at lowermost cyme in spike up to $30 \times 7 \mathrm{~mm}$, conduplicate, glabrous. Calyx drying brown-green, anterior and posterior lobes subequal, elliptic, $26.5-28.5 \times 12-14 \mathrm{~mm}$ in fruit, base cuneate, margin entire, apex of anterior lobe notched with two triangular lobes 1.7 - $4 \mathrm{~mm}$ long, posterior lobe acute-apiculate, surfaces glabrous except for sparse inconspicuous hairs along margin, with prominent palmate venation; lateral lobes linear-lanceolate, 14 - $14.5 \mathrm{~mm}$ long in fruit, ciliate. Corolla and androecium not seen. Pistil glabrous; stigma not seen. Capsule 4-seeded, 20 - $20.5 \mathrm{~mm}$ long including 5.5 $6 \mathrm{~mm}$ long beak, glabrous; seeds $5.5-6.5 \times 5.2-5.7 \mathrm{~mm}$.

DISTRIBUTION. Apparently endemic to West Angola (Cuanza Sul Prov.); Map 4.

COllection Studied. ANGolA. Cuanza Sul, Cela, fr. June 1951, Teixeira s.n. (PRE!).

HABITAT \& ECOLOGY. The habitat was not recorded on the single specimen seen, which was collected from c. 1400 m elevation.

CONSERVATION STATUS. As the status of this species is not fully resolved and its habitat requirements are unknown, it is assessed as Data Deficient - DD.

NOTES. This is a very striking species known only from a single fruiting specimen. The dense contracted fruiting spikes are reminiscent of Barleria benguellensis but it differs from that species in the much larger leaves with a rounded or subcordate base, the elliptic calyces with a cuneate base (not ovate with base rounded or subcordate), and the much stouter stems which appear to be erect (not trailing). Barleria benguellensis is also likely to have 2-seeded capsules like the closely related $B$. violascens and $B$. polyneura. Of the 4-seeded species, it is most likely to be confused with B. kacondensis subsp. glabrescens which can have contracted terminal inflorescences and is largely glabrous but that species differs in having much narrower, oblong-elliptic to lanceolate leaves up to $3.6 \mathrm{~cm}$ wide, with l:w ratio $3.6-4.6: 1$ compared to c. 2: 1 in the Teixeira specimen, and the compound inflorescences are not nearly so dense as in this specimen. Flowering material of this undescribed species is required.

53. Barleria eburnea I.Darbysh. sp. nov. Type: Angola, Bié, a $10 \mathrm{~km}$ de Silva Porto [Kuito] para Chinguar, fl. 21 March 1971, Moreno E Lopes 339 (holotype LISC! [LISC043659]).

http:/ /www.ipni.org/urn:lsid:ipni.org:names:77215733-1

Dwarf perennial herb, few- to many-branched from a small woody rootstock, sometimes with a short rhizome, with fleshy roots; stems erect or decumbent, 10 - $35 \mathrm{~cm}$ tall, 4-ridged, glabrous or puberulous mainly 
on two opposite sides between the ridges. Leaves sessile or petiole to $6 \mathrm{~mm}$ long; blade somewhat coriaceous, glaucous-green but drying dark green or green-black, elliptic to narrowly so, ovate-elliptic or obovate-elliptic, $4.5-6.7 \times 1.6-2.7 \mathrm{~cm}$ (l:w ratio $2-3.5$ : 1 ), base cuneate or attenuate, margin entire, apex acute to obtuse, apiculate, surfaces glabrous; lateral veins $4-8$ pairs, these and reticulate tertiary venation prominent beneath. Inflorescences of single-flowered cymes in the upper axils; bracts foliaceous but those towards stem apices much reduced, typically narrowly oblong-elliptic, $20-33 \times 3.5-8 \mathrm{~mm}$; peduncle $1-6.5 \mathrm{~mm}$ long or cymes at lowermost fertile axils with peduncle up to $13 \mathrm{~mm}$ long; bracteoles ascending-arcuate, subulate to oblanceolate, $(13.5-) 17-28.5 \times 2.5-5(-7.5) \mathrm{mm}$, markedly conduplicate, apex acute or rounded, surfaces glabrous; pedicels $1.7-3.5 \mathrm{~mm}$ long. Calyx drying dark green, green-brown or green-black with darker palmate venation, accrescent; anterior lobe broadly ovate, $24-28 \times 14-16.5 \mathrm{~mm}$ in flower, up to $30 \times 23 \mathrm{~mm}$ in fruit, base cordate, margin entire, apex obtuse, rounded or emarginate, external surface glabrous or with few short hairs along margin, internal surface sometimes puberulent; posterior lobe as anterior lobe but $27-32.5 \mathrm{~mm}$ long in flower, up to $33.5 \times 26 \mathrm{~mm}$ in fruit, apex obtuse or acute; lateral lobes linear-lanceolate or lanceolate, $7-8 \mathrm{~mm}$ long in flower, up to $10 \mathrm{~mm}$ long in fruit, puberulent. Corolla 28 $31 \mathrm{~mm}$ long, white, cream or pale yellow with purple in throat, glabrous externally; tube 10.3 - $11.7 \mathrm{~mm}$ long, broadly cylindrical below insertion point of stamens where $3.5-4.5 \mathrm{~mm}$ in diam., narrowly funnel-shaped above, mouth $5.5-6 \mathrm{~mm}$ in diam.; limb subregular, abaxial lobe broadly obovate, $16-20 \times 12-13 \mathrm{~mm}$, apex emarginate; lateral lobes oblong-obovate, $18-19 \times 11.5-$ $13 \mathrm{~mm}$, apices rounded or emarginate; adaxial lobes broadly obovate, $15-16.2 \times 11-13 \mathrm{~mm}$. Stamens inserted $4-5 \mathrm{~mm}$ from base of corolla tube; filaments $6.5-8 \mathrm{~mm}$ long; anthers $\pm 3.5 \mathrm{~mm}$ long, held at corolla mouth; lateral staminodes well developed, $2-2.7 \mathrm{~mm}$ long. Pistil glabrous; stigma linear, c. 3 - $3.5 \mathrm{~mm}$ long, curved. Capsule 4-seeded, 23 - $24 \mathrm{~mm}$ long including beak $5 \mathrm{~mm}$ long, glabrous; seeds c. 8 mm long. Figs $10 \& 11 \mathrm{~A}$.

RECOGNITION. Barleria eburnea is superficially similar to $B$. polyneura but differs in the stems being erect or decumbent (vs trailing or at most weakly ascending); the capsule being 4-seeded (vs 2-seeded); the leaves being \pm elliptic with base cuneate or attenuate (vs leaves \pm ovate with base rounded, subcordate or obtuse); the staminal filaments being shorter (6.5 $8 \mathrm{~mm}$ long, vs $10.5-12 \mathrm{~mm}$ ) and the bracteoles being longer and ascending-arcuate, (13.5 -) $17-28.5 \mathrm{~mm}$ long (vs spreading, $5-18 \mathrm{~mm}$ long). It is similar to B. pabularis in corolla morphology but differs in the outer calyx lobes being broadly ovate with base cordate and external surface largely glabrous (vs oblong-ovate with base rounded and external surfaces glandular-pubescent in B. pabularis), in the flowers being less markedly aggregated into a terminal spike, and in the bracteoles being narrower, 2.5 - 5 (7.5) $\mathrm{mm}$ wide, subulate to oblanceolate and conduplicate (vs bracteoles more broadly oblanceolate, 6 $10 \mathrm{~mm}$ wide, and not conduplicate).

DISTRIBUTION. Endemic to central and southern Angola (Bié, Cuando Cubango, Huambo and Huíla Provs.); Map 4.

ADDITIONAL COLLECTIONS STUDIED. ANGOLA. On the left bank of R. Kuebe [Cuebe] near Munongue [Menongue], fr. 19 April 1906, Gossweiler 3578 (BM!, BR, K!); Cola am R. Que, in bud, April 1954, Boss s.n. (M!); Bié, entre Cangalo e Andulo ao km 56 do Vouga, fl. 22 Feb. 1970, Raimundo et al. 120 (LISC!); Nova Lisboa [Huambo], Centro de Estudos da Chianga, fl. 18 April 1972, Lopes 319 (LUAI!); Bié, comunidade Ulomba, fl. 28 March 2007, Leyens 301 (FR*); Chitembo, Cusseque study area, plot 26274, fl. 5 March 2014, Maiato FM 1010 (139206) (K!, LUBA) \& idem, plot 26275, fl. 5 March 2014, Maiato FM 1011 (139206) (K!, LUBA).

HABITAT \& ECOLOGY. This species is recorded from miombo woodland dominated by Julbernardia paniculata (Benth.) Troupin, Erythrophleum africanum (Welw. ex Benth.) Harms, Brachystegia spiciformis Benth., Pseudolachnostylis maprouneifolia Pax and Baphia bequaertii De Wild., and in degraded wooded grassland, growing in sandy soils; it occurs at $\pm 1300-1750$ m elevation.

CONSERVATION STATUS. This species is fairly widespread in the miombo woodlands of central and southern Angola, with an EOO of $59,983 \mathrm{~km}^{2}$ based on current evidence. This is well in excess of the maximum 20,000 $\mathrm{km}^{2}$ for threatened taxa under IUCN Criterion B1. Although few collections are known, with only six confirmed locations to date, this is likely to be a reflection of the highly incomplete botanical inventory of central Angola rather than of this species' actual abundance. Large areas of its EOO have been degraded or transformed due to high population densities throughout its range (Mendelsohn 2019, Figs. 8.1 \& 8.8). Much of the woodland cover of western Bié Province, for example, was cleared for crops in the $1950 \mathrm{~s}-1970$ s prior to the civil war (Mendelsohn 2019). However, this species appears, from the limited evidence available, to be able to tolerate some disturbance as it has been recorded from degraded wooded grassland. It is therefore provisionally assessed as Least Concern LC, but with more data on its current range and threats desirable to help confirm this assessment.

ETYMOLOGY. The species epithet "eburnea", meaning "ivory white", refers to the corolla colour of this species. NOTES. This species has previously been confused in herbaria with Barleria polyneura and the two are 


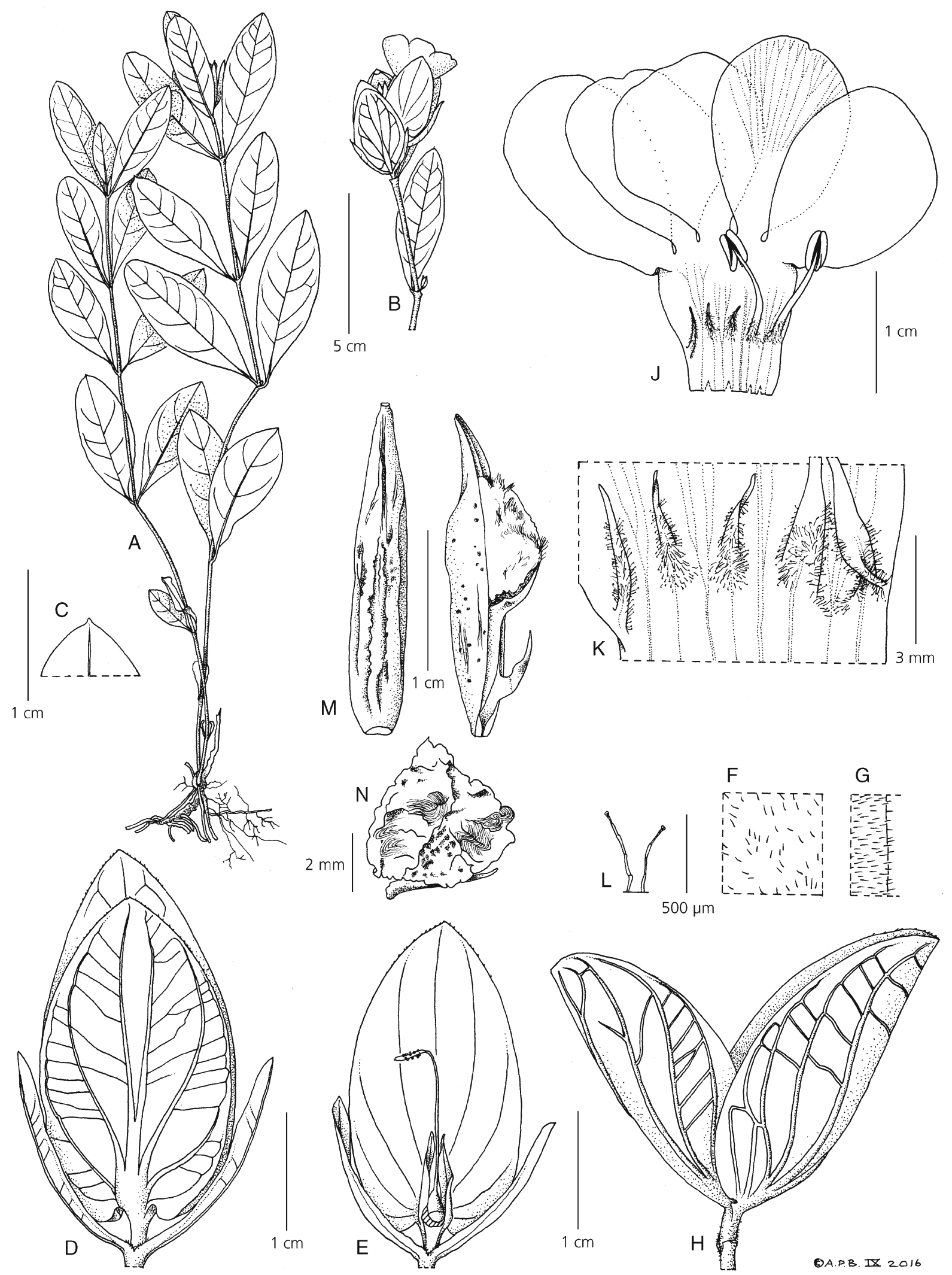

Fig. 10. Barleria eburnea. A habit, vegetative parts; B habit, flowering stem; C leaf apex showing apiculum; D calyx with subtending bracteoles, at flowering stage; E calyx with anterior lobe removed to reveal lateral lobes and pistil; $F$ indumentum of inner surface of posterior calyx lobe; G indumentum of lateral calyx lobe; $\mathrm{H}$ calyx at fruiting stage; J dissected corolla with androecium; $\mathrm{K}$ detail of staminodes and staminal filament bases; L typical glandular hair on staminodes; $\mathrm{M}$ capsule valve, face view and lateral view with one of two seeds in situ; $\mathrm{N}$ immature seed with retinaculum. A, C from Raimundo et al. 120, B, D - G, J - L from Maiato 1010 (139206); H, M, N from Gossweiler 3578. DRAWN BY ANDREW BROWN. 

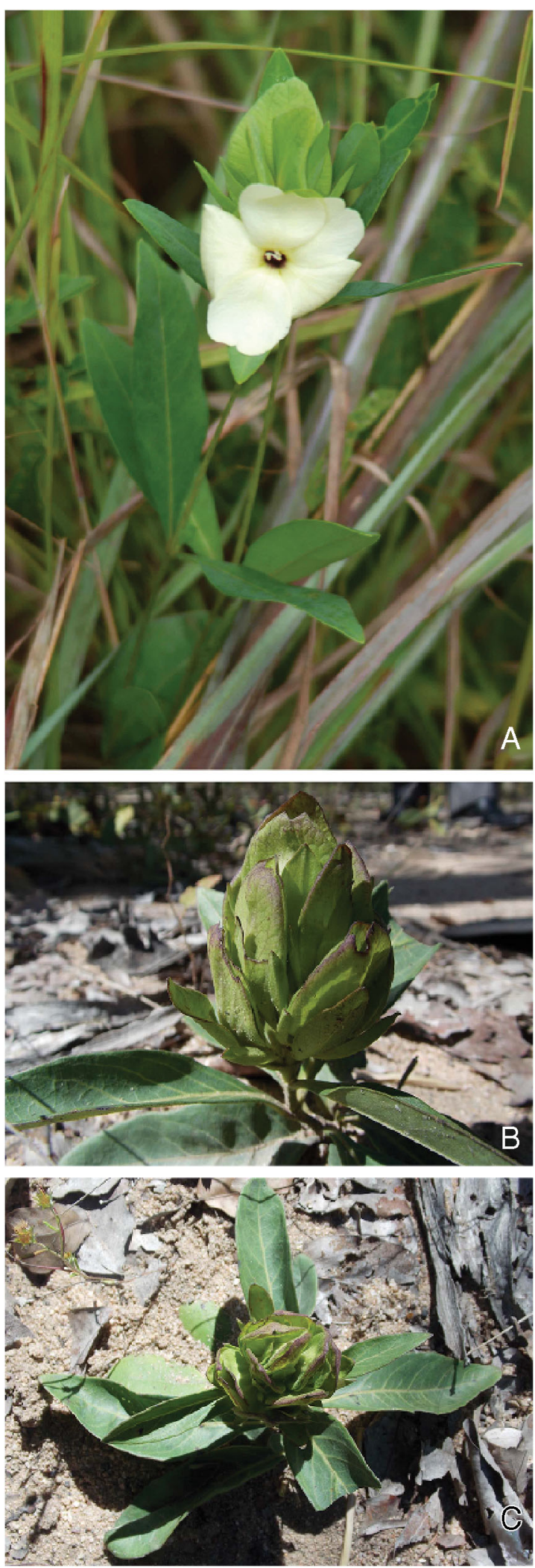

Fig. 11. A Barleria eburnea, flowering stem (collected as Leyens 30). B, C Barleria pabularis, B inflorescence; C habit, viewed from above. PHOTOS: A T. LEYENS, ANGOLA; B, C F. M. P. GONÇALVES (ALL ANGOLA). superficially similar but are easily separated by a number of characters as listed in the Recognition section above and they are unlikely to be closely related, particularly based on differing seed number. The small flowers of B. eburnea, with a short corolla tube and correspondingly short stamens, is quite striking. The closest species in this regard is $B$. pabularis but that species has glandular hairs present on the calyces and has a more congested inflorescence with larger bracteoles and so looks quite unlike B. eburnea (see Fig. 11).

54. Barleria pabularis S.Moore (1911: 307; 1930: 135); Klopper et al. (2006: 4); Makholela (2008: 22). Type: Angola, near Munongue [Menongue], fr., date not on sheet [1906 - 1907], Gosswelier 3083 (lectotype BM! [BM000931089], selected here; isolectotype K! [K000913669]). Additional syntype: Angola, Anha, fl. March 1907, Gossweiler 3622 (BM! [BM000931088]).

Barleria welwitschii sensu Benoist (1950: 16), non S.Moore (1880: 267).

Dwarf perennial herb, several branched from a woody rhizome, with reddish fleshy adventitious roots; stems erect, decumbent or procumbent, $5-20 \mathrm{~cm}$ tall, unbranched or few-branched, 4-angular, spreadingpubescent on two opposite sides between the ridges and with or without sparse to numerous glandular hairs. Leaves sessile or petiole to $7 \mathrm{~mm}$ long; blade narrowly oblong-elliptic to oblanceolate, $7.8-10.8 \times 1.9-3.5 \mathrm{~cm}$ (l:w ratio $3.8-5: 1$ ), base cuneate or attenuate, margin entire, apex acute to rounded, apiculate, surfaces glabrous or margin, midrib and main veins beneath strigulose; lateral veins 5 - 6 pairs. Inflorescences of singleflowered cymes aggregated into a terminal few-flowered head; bracts oblanceolate or oblong-elliptic, $27-56 \times$ $11.5-21 \mathrm{~mm}$; cymes sessile or peduncle to $2 \mathrm{~mm}$ long; bracteoles ascending, oblanceolate, $21-34 \times 6-10 \mathrm{~mm}$, apex usually rounded or obtuse, margin and midrib strigulose, surfaces with sparse to numerous glandular hairs or largely glabrous; pedicels $2-2.5 \mathrm{~mm}$ long, puberulous. Calyx drying dark green, green-brown or blackish-green; anterior and posterior lobes subequal, oblong-ovate, $26-30 \times 14.5-18 \mathrm{~mm}$, base rounded, margin entire, often revolute, apex of anterior lobe emarginate or rounded, often revolute, posterior lobe obtuse, external surfaces glandular pubescent or sparsely so, main veins and margin strigulose; lateral lobes straw-coloured, lanceolate, 11.5 - 12.5 mm long, glandular-puberulous. Corolla [only one measured] c. $35 \mathrm{~mm}$ long, white, cream-coloured or "yellow with blue throat", glabrous externally; tube $13 \mathrm{~mm}$ long, cylindrical below insertion point of stamens where $4 \mathrm{~mm}$ in diam., widened above, mouth $5.5-7 \mathrm{~mm}$ in diam.; limb subregular, lobes broadly obovate, abaxial lobe 19.5 $\times 19 \mathrm{~mm}$, lateral lobes $21 \times 17.5-18 \mathrm{~mm}$, adaxial lobes $19.5 \times 15.5 \mathrm{~mm}$, apices emarginate. Stamens 
inserted $5.3 \mathrm{~mm}$ from base of corolla tube; filaments $8.5 \mathrm{~mm}$ long; anthers held in corolla throat, 3.7 - $4 \mathrm{~mm}$ long; lateral staminodes 1.1 $1.3 \mathrm{~mm}$ long. Pistil glabrous; stigma linear, c. $2 \mathrm{~mm}$ long. Capsule 4-seeded, 19 - $20.5 \mathrm{~mm}$ long including beak 5.5 - $6 \mathrm{~mm}$, glabrous; only immature seeds seen. Fig. 11B \& C.

DISTRIBUtION. Endemic to Southwest and SouthCentral Angola (Cuando Cubango, Huambo and Huíla Provs.); Map 1.

ADditional COlLeCtions StUdied. ANGOLA. Planalto de Benguela, Nova Lisboa [Huambo], fl. 4 March 1938, Gossweiler 11975 (BM!, COI*); Menongue, Cuchi, fl. 26 March 1960, Mendes 3294 (K!, LISC!); Chipindo, Bambi, near Lino village, fl. bud, 2017, F. M. P. Gonçalves sight record (photo.!).

HABITAT \& ECOLOGY. This species is recorded from open woodland, fire-prone wooded grassland and from shaded or open situations in "pasturage" with open thickets, at $1400-1650$ m elevation.

CONSERVATION STATUS. The EOO of this species, based on known occurrence data, is $30,621 \mathrm{~km}^{2}$ and it is known from five localities, but botanical exploration has been very limited to date within much of its range. Although information on its habitat preferences is very limited, it does appear to tolerate some disturbance as it has been recorded from open pasture land. That said, the west and central parts of its EOO are heavily populated with much ongoing degradation or transformation of natural habitats (Mendelsohn 2019, Figs. 8.1 \& 8.8), and this may have impacted some subpopulations of this species, but this requires confirmation. Given the relatively large EOO, this species is provisionally assessed as of Least Concern LC, but with more information desirable on its current abundance, range and threats.

NOTES. Benoist (1950) identified Gossweiler 11975 from Huambo as Barleria welwitschii. The duplicate of this specimen at BM is not very informative - the calyces are mainly hidden behind the bracts and so not easy to observe and there are no corollas present. However, the glandular hairs on the inflorescence are much sparser than in the type specimen of $B$. welwitschii, and it is a better match for $B$. pabularis. These two species are similar but $B$. pabularis is separated by its larger bracts and bracteoles and in particular its larger, more ovate outer calyx lobes with a rounded (not obtuse) base and with a less dense glandular indumentum.

This species has a rather untidy appearance due to its low growth habit (perhaps related to its preference for grazed or fire-prone savannas) with large foliage and bracts which can partially hide the flowers; see Fig. 11B \& C. Bamps E $\mathcal{F}^{\circ}$ Martins 4413 (Vila Flor Cacoma, Chavaca, fl. \& fr. 6 April 1973, BR*, K!) has a similar growth habit but it lacks a glandular indumentum on the calyces and also has proportionately broader, elliptic or obovate leaves and more ovate-cordate outer calyx lobes. More material is needed from that locality to determine whether this is a form of Barleria pabularis or a different species.

55. Barleria welwitschii S.Moore (1880: 267); Clarke (1899: 158); Hiern (1900: 816); Klopper et al. (2006: 5); Makholela (2008: 22). Type: Angola, Pungo Andongo, inter Lombe et Quibinde, fl. 9 March 1857, Welwitsch 5091 (lectotype BM! [BM000931113], selected here; isolectotypes K! [K000394515], LISU! [LISU223401]).

Dwarf perennial herb with a small woody rhizome and fleshy adventitious roots; stems erect or soon decumbent, $10-30 \mathrm{~cm}$ tall, unbranched or few-branched, 4ridged, shortly spreading-pubescent particularly on two opposite sides between the ridges. Leaves on petiole to $16 \mathrm{~mm}$ long; blade oblanceolate or elliptic-oblanceolate, $6-11 \times 2.4-4.9 \mathrm{~cm}$ (1:w ratio $2.8-3.4: 1)$, broadest towards stem base, base long-attenuate, margin entire, apex acute or obtuse, surfaces glabrous except midrib above pubescent and main veins beneath sparsely strigulose; lateral veins $5-6$ pairs. Inflorescences of single-flowered cymes aggregated into a few-flowered head or spike up to $5 \mathrm{~cm}$ long; bracts oblanceolate, those at base of spike up to $52 \times 14 \mathrm{~mm}$, those towards apex of spike typically $19-31 \times 6-9 \mathrm{~mm}$; peduncle of each cyme 1 - $4.5 \mathrm{~mm}$ long, puberulous; bracteoles held erect, oblanceolate or linear, $11-22 \times 2-5.2 \mathrm{~mm}$, apex acute to rounded, surfaces glandular-pubescent, margin and main veins strigulose; pedicels $1.5-4 \mathrm{~mm}$ long. Calyx drying brown towards apex, paler towards base; anterior and posterior lobes subequal, obovate or obovateelliptic, $18-25 \times 8-16 \mathrm{~mm}$, base obtuse, margin entire, apex of anterior lobe emarginate, rounded or obtuse, posterior lobe obtuse, external surfaces glandularpubescent and with interspersed short eglandular hairs, main veins and margin strigulose; lateral lobes strawcoloured, linear-lanceolate, 6.5 - $7.5 \mathrm{~mm}$ long, puberulous. Corolla $32-36 \mathrm{~mm}$ long, white, glabrous externally; tube $15-16.5 \mathrm{~mm}$ long, cylindrical below insertion point of stamens where $3.5 \mathrm{~mm}$ in diam., barely widened above, mouth $5.5-6 \mathrm{~mm}$ in diam.; limb subregular, lobes broadly obovate, $15.5-19 \times 12.5-16$ $\mathrm{mm}$, apices emarginate, lateral lobes somewhat larger than the other lobes. Stamens inserted $5.5-7 \mathrm{~mm}$ from base of corolla tube; filaments $8-8.5 \mathrm{~mm}$ long; anthers held in corolla throat, $\pm 4 \mathrm{~mm}$ long; lateral staminodes $1.3-1.6 \mathrm{~mm}$ long. Pistil glabrous; stigma linear, $\pm 1.9 \mathrm{~mm}$ long. Capsule not seen.

DISTRIBUTION. Endemic to North Angola (Malanje Prov.), known only from the type specimen; Map 1. 
HABITAT \& ECOLOGY. Welwitsch recorded Barleria welwitschii from rocky ground at $1650 \mathrm{~m}$ altitude; no further habitat details are available.

CONSERVATION STATUS. This species is currently known only from the type specimen collected over 150 years ago. However, the Pungo Andongo area has not been well botanised since Welwitsch's time. With very little habitat information for this species and with no information on its current abundance, it must be considered Data Deficient - DD, but it may well prove to be threatened and there is an urgent need to rediscover this species.

56. Barleria louiseana I.Darbysh. sp. nov. Type: Angola, Chianga, faz. médias, colonato da Cela, fl. 27 Nov. 1961, Teixeira EF Figueira 5911 (holotype LUBA!).

http:/ /www.ipni.org/urn:lsid:ipni.org:names:77215734-1

Dwarf perennial herb, several-branched from a woody rhizome, with fleshy adventitious roots; stems erect, 20 - $30 \mathrm{~cm}$ tall, unbranched or few-branched, 4-ridged, pale-puberulous particularly on two opposite sides between the ridges. Leaves subsessile; blade pale green but drying dark green, mid-cauline leaves elliptic, oblong-elliptic or somewhat obovate, $6-11 \times 2.5-\mathrm{c}$. $4.8 \mathrm{~cm}$ (l:w ratio $(1.75-) 2.2-3.5: 1)$, base cuneate to obtuse, margin entire, apex acute or obtuse, surfaces puberulous mainly on margin, midrib and lateral veins beneath; lateral veins $5-7$ pairs, these and reticulate tertiary venation rather prominent on both surfaces; uppermost leaves ovate with base rounded or shallowly cordate, $3.3-6.5 \times 2.4-3 \mathrm{~cm}$. Inflorescences of singleflowered cymes aggregated into short dense spikes 4 $6 \mathrm{~cm}$ long; bracts obovate or elliptic, those towards base of spike typically $27-34 \times 15-25 \mathrm{~mm}$, those towards apex of spike typically $20-25 \times 9-18 \mathrm{~mm}$, puberulous mainly along margin and main veins; cymes sessile or peduncle to $3 \mathrm{~mm}$ long; bracteoles held erect, oblanceolate or narrowly oblong-elliptic, $14-22 \times 2.8-6.7 \mathrm{~mm}$, apex acute to obtuse, surfaces puberulous on margin and midrib and hairs more widespread towards base, tripli-veined; pedicels 2 $2.5 \mathrm{~mm}$ long. Calyx drying dark green or green-brown towards apex, paler towards base; anterior lobe broadly obovate, $20-21.5 \times 13-17 \mathrm{~mm}$, base cuneate, margin entire, apex rounded, truncate or shallowly emarginate, external surface puberulous particularly on margin and palmate primary veins; posterior lobe as anterior lobe but broadly elliptic or obovate, 22 - $23.5 \times 15.5$ - $18.5 \mathrm{~mm}$, apex rounded; lateral lobes straw-coloured, linear-lanceolate, 9.5 $10 \mathrm{~mm}$ long, puberulous. Corolla c. $37 \mathrm{~mm}$ long, white or cream, glabrous externally; tube c. $13 \mathrm{~mm}$ long, cylindrical below attachment point of stamens where
$4 \mathrm{~mm}$ in diam., funnel-shaped above, mouth $7.5 \mathrm{~mm}$ in diam.; limb subregular, adaxial lobe slightly offset by c. $2 \mathrm{~mm}$, all lobes broadly obovate, c. $18-21 \mathrm{~mm}$ long and wide, apices emarginate. Stamens inserted $5.5 \mathrm{~mm}$ from base of corolla tube; filaments $\pm 8.5 \mathrm{~mm}$ long, with numerous short-stalked or subsessile glands throughout; anthers held in corolla throat, $\pm 5 \mathrm{~mm}$ long; lateral staminodes $\pm 1.5 \mathrm{~mm}$ long, densely glandular-puberulent. Pistil glabrous; stigma linear, 1.3 - 1.7 mm long, curved. Capsule not seen. Fig. 12.

RECOGNITION. Barleria louiseana resembles B. welwitschii but is easily separated by having subsessile leaves, the uppermost pairs being ovate with a rounded or shallowly cordate base (vs leaves petiolate, uppermost pairs oblanceolate with an attenuate base in $B$. welwitschii); a fine eglandular-puberulous indumentum on the bracteoles and calyces (vs bracteoles and calyces glandular-pubescent and with strigulose hairs along the main veins and margin); in the staminal filaments having short-stalked or subsessile glands throughout (vs glabrous except for glandularpuberulous base) and in the anthers being longer, \pm $5 \mathrm{~mm}$ (vs $\pm 4 \mathrm{~mm}$ long).

DISTRIBUtION. Endemic to West Angola (Cuanza Sul and Huambo Provs.); Map 1.

ADDitional COlLections StUdied. ANGOla. "Long. E. $15^{\circ} 05^{\prime} \times$ Lat. S. $12^{\circ} 44^{\prime \prime}$, fl. 17 Feb. 1908 [possibly the date received at Kew], Wellman 1825 (K!); Chianga, colonato da Cela, fl. 27 Nov. 1961, Teixeira E Andrade 6203 (LUBA!).

HABITAT \& ECOLOGY. The habitat was not recorded on the specimens seen; Teixeira and Andrade made the note "terrenos 20" but we have not had access to the associated habitat description. However, Aguiar \& Diniz (1972) produced a vegetation map of the western Cela plateau and noted the natural vegetation to be dominated by miombo woodland (Julbernardia, Brachystegia and Isoberlinia spp.) assemblages. It occurs at c. $1600 \mathrm{~m}$ elevation.

CONSERVATION STATUS. This species is currently known from two historic locations c. $150 \mathrm{~km}$ apart. It was recorded as frequent by Teixeira \& Figueira (their number 5911) at Cela in 1961 but this area is now heavily settled and with extensive conversion of natural habitats to both subsistence and commercial agriculture, as evidenced in Google Earth imagery. Even in the early 1970s, this area was dominated by farmland and secondary vegetation (Aguiar \& Diniz 1972), and there has been some marked "forest cover" loss between 2000 and 2015 in the southern part of this region (Mendelsohn 2019, Fig. 8.1). The locality of the Wellman collection in Huambo Province is rather vague — it lies south of the Mount Moco Special Reserve in an unprotected area. Palacios et al. (2015) report high rates of miombo woodland loss in Huambo, reducing from $78.4 \%$ province-wide in 2002 to only $48.3 \%$ in 2015 , with much of the reduction attributable to expansion of croplands. Given the 


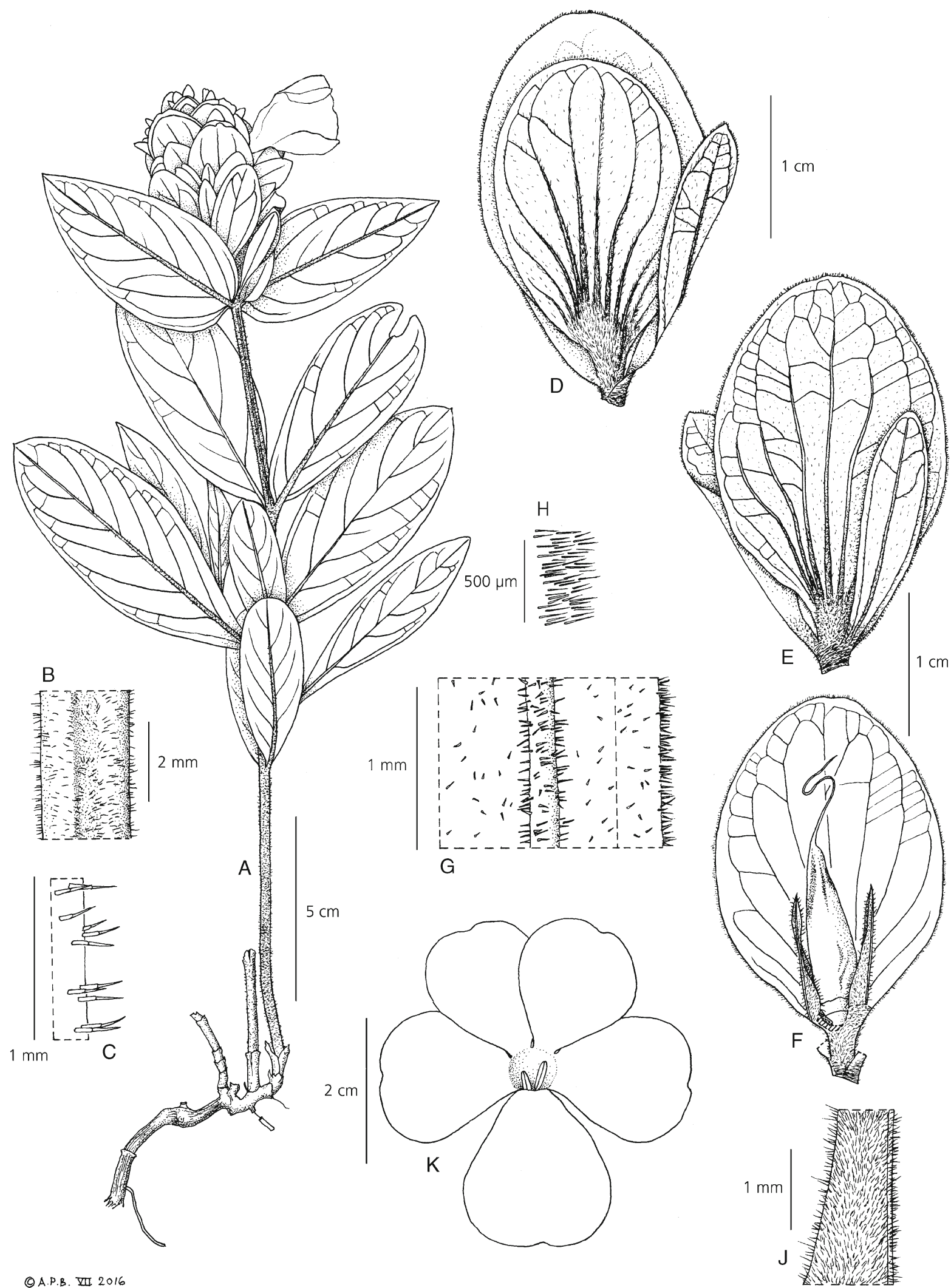

Fig. 12. Barleria louiseana. A habit; $B$ young stem indumentum; C detail of hairs in B; D calyx with subtending bracteoles, anterior view; E calyx with subtending bracteoles, posterior view; $\mathrm{F}$ calyx with anterior lobe removed to reveal lateral lobes and maturing pistil; $\mathbf{G}$ detail of indumentum of posterior calyx lobe, including margin (right); $\mathbf{H}$ detail of hairs on margin of posterior calyx lobe; J portion of lateral calyx lobe showing indumentum; K flower, reconstructed face view. A - C from Teixeira \& Figueira 5911, D - J from Teixeira \& Andrade 6203. DRAWN BY ANDREW BROWN. 
high level of threat to natural habitats within its range and the apparent scarcity of this species, it is provisionally assessed as Endangered - EN B2ab(iii) but with more information on current range, abundance and threats desirable.

ETYMOLOGY. Barleria louiseana is named in honour of my [I.D.'s] wife Louise, to thank her for her unending support. NOTES. This very distinctive and attractive species is known from only three collections. The two Teixeira specimens are excellent material and are clearly distinct from the most likely confusion species, Barleria welwitschii, using the characters listed in the Recognition section. The Wellman specimen is very poor material but is a good match for the two Teixeira collections particularly in the distinctive inflorescence indumentum. The description of the corolla is somewhat incomplete because there was no material available for dissection, hence only approximate measurements are given for some of the corolla dimensions.

Barleria sect. Stellatohirta M.Balkwill (in Balkwill \& Balkwill 1998: 110); Balkwill \& Balkwill (1997: 569); Darbyshire (2008: 261 - 268; 2010: 379; 2015: 85).

Barleria subgen. Eu-Barleria "Stellato-hirtae" sensu Clarke (1899: 143), pro parte excl. B. fulvostellata.

Barleria sect. Eubarleria subsect. Thamnotrichae sensu Obermeyer (1933: 139).

Axillary spines absent. Indumentum stellate or dendritic, sometimes also with interspersed simple hairs. Inflorescences of single-flowered subsessile cymes compounded into dense terminal globose heads or spikes; bracts highly modified. Corolla white, blue or purple; tube subcylindrical; limb in " $4+1$ " configuration or subregular. Staminodes 2 ($3)$, lateral pair with antherodes \pm well developed or rarely absent; if adaxial staminode present then minute, antherode absent. Pistil with style base swollen; stigma linear. Capsule laterally flattened, fusiform, unbeaked or shortly beaked; lateral walls often thin, remaining attached to or tearing slightly from the thickened flanks at dehiscence; septum largely membranous; seeds 2, discoid with dense buff-coloured hygroscopic hairs.

NOTES. This section comprises 12 species, confined to Africa and Arabia with centres of diversity in the fireprone miombo woodlands of East Africa and Angola. It is easily recognised by having the combination of a stellate or dendritic indumentum, dense terminal heads or spikes of flowers and 2-seeded capsules without or with only a short beak and with a largely membranous septum (Balkwill \& Balkwill 1997; Darbyshire 2008; Darbyshire et al. 2019b). In Angola and Namibia, a stellate or dendritic indumentum is confined to sect. Stellatohirta.

In addition to the five species of sect. Stellatohirta enumerated here, Barleria purpureotincta I.Darbysh. was also noted in Flora Zambesiaca to occur in Angola (Darbyshire 2015: 90). This record was based on the specimen Pocock 214 which was collected on 9 May 1925, with the locality recorded as "RhodesiaAngola, woodland near Kassassa". However, based on the itinerary of Mary Pocock's travels set out in Balarin et al. (1999) and her diary entries reproduced in Dold \& Kelly (2018), it is clear that she did not cross from Zambia into Angola until approx. 12 May 1925 (she was in the border area on $11^{\text {th }}$ May - her numbers 248 onwards) and, although Kassassa has not been precisely located, it is believed to have been on the Zambian side of the border near Lukona. Tellingly, Pocock 241, a specimen of Drosera indica L., is labelled as "between Kassassa and Angolan border" (Balarin et al. 1999). In light of this information, B. purpureotincta reverts to being a Zambian endemic. That said, its range is very likely to extend into the highly under-botanised eastern Moxico Province of Angola and so this species is included in the key to sect. Stellatohirta here.

With the exception of Barleria taitensis subsp. occidentalis, the species of sect. Stellatohirta in Angola are known from few collections, and further material is highly desirable.

\section{Key to species of Barleria sect. Stellatohirta in Angola and Namibia}

1 Bracts, bracteoles and outer calyx lobes with short spinulose or apiculate tips; mature inflorescences often spiciform or

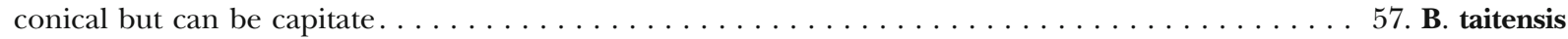

Bracts, bracteoles and outer calyx lobes lacking spinulose or apiculate tips, plants unarmed; mature inflorescences capitate, subglobose or rarely (in fruit) conical $\ldots \ldots \ldots \ldots \ldots \ldots$

2 Leaves markedly discolourous, lower surface entirely covered in white to cream-yellow stellate or dendritic hairs; corolla white or cream-coloured; anthers $4.7-5.7 \mathrm{~mm} \operatorname{long} \ldots \ldots \ldots \ldots \ldots \ldots \ldots$. . buddleioides

Leaves not so markedly discolourous, lower surface can have dense stellate hairs but these not entirely obscuring the surface; corolla (where known) blue, purple, lilac or rarely white; anthers $2.5-4.3 \mathrm{~mm} \mathrm{long} \mathrm{\ldots ...} 3$

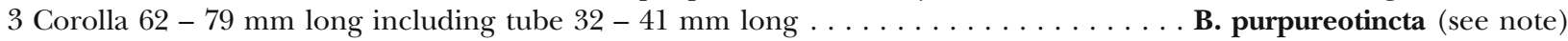




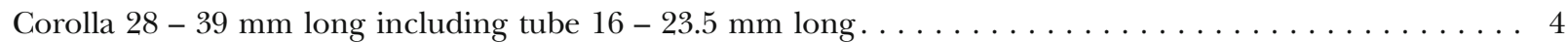

4 Branches markedly heterophyllous, distal leaf pairs linear-lanceolate, l:w ratio 6.2 - 7.9: 1, lower surface with numerous wispy white long-armed stellate hairs; anterior calyx lobe with predominantly simple hairs externally, long-armed

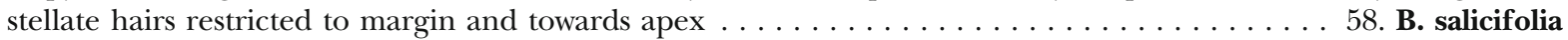

Branches somewhat heterophyllous but not so markedly so, distal leaf pairs oblong-elliptic, lanceolate or somewhat oblanceolate, l:w ratio 2.7 - 5.2: 1, lower surface with golden-brown to pale buff long-armed stellate hairs and dendritic hairs, not wispy; anterior calyx lobe with long-armed stellate to dendritic hairs externally . . . . . . 5

5 Bracts and bracteoles with conspicuous dark purple distal portion contrasting with pale base and veins; lateral corolla

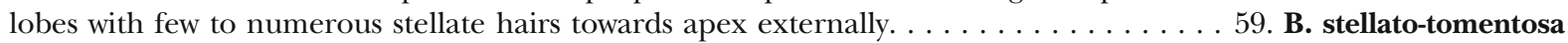

Bracts and bracteoles sometimes pink-tinged but lacking conspicuous dark purple distal portion; corolla glabrous or with very few hairs at apex of lateral lobes only $\ldots \ldots \ldots \ldots \ldots \ldots \ldots \ldots \ldots$. subglobosa

57. Barleria taitensis S.Moore (1902b: 343); Klopper et al. (2006: 5); Darbyshire (2010: 380; 2015: 86). Type: Kenya, [Makindu] Kiumbi R., fl. 14 April 1902, Kässner 600 (holotype BM! [BM000931084]; isotypes $\mathrm{K}$ ! [K000394446], MO* [MO-391481]).

Barleria stellato-tomentosa S.Moore var. ukambensis Lindau (1894: 23). Syntypes: Kenya, Ukambani, fl. June 1877, Hildebrandt 2722 \& 2722a (B十); Ndara (Taita), fl. Feb. 1877, Hildebrandt 2457 (B十).

Barleria salicifolia sensu Clarke (1899: 162), pro parte quoad Hildebrandt 2722, 2722a \& 2457 ex Kenya \& Smith s.n. ex Tanzania, non S.Moore.

Erect or scrambling subshrub, $30-250 \mathrm{~cm}$ tall; young stems with dense golden dendritic hairs, many with a long \pm antrorse arm. Leaves sessile or petiole to $5 \mathrm{~mm}$ long; blade elliptic (-obovate) or lanceolate, $2.5-13 \times 0.8-3.3 \mathrm{~cm}(\mathrm{l}: \mathrm{w}$ ratio $2.1-3.5: 1$ ), base cuneate or attenuate, apex acute to rounded, apiculate, upper surface with pale long-armed stellate hairs, lower surface with dense whitish (-buff) stellate hairs, veins and margin with golden to pale-buff long-armed stellate hairs; lateral veins $4-6$ pairs, impressed above, prominent beneath. Inflorescences terminating main and short lateral branches, spiciform, conical or subcapitate, $1.5-7.5 \mathrm{~cm}$ long; bracts narrowly elliptic, obovate, oblong or lanceolate, $9.5-21 \times 2-7 \mathrm{~mm}$, apex dark-spinulose or -apiculate, \pm outcurved; bracteoles (linear-) lanceolate or oblanceolate, $7-16 \times 1-3$ (-4) $\mathrm{mm}$, conduplicate in cross section, apex darkspinulose, \pm outcurved. Calyx anterior lobe ovate, subrhombic or rounded, $11.5-22 \times 6-16 \mathrm{~mm}$, base obtuse to attenuate, margin entire, often involute, apex attenuate into two parallel to widely divergent darkspinulose or apiculate tips, palmate venation prominent, surface with \pm dense fine pale grey (-buff) stellate hairs and with golden to pale-buff appressed or ascending long-armed stellate hairs along veins and margin, or those along margin sometimes more spreading and with a swollen base; posterior lobe ovate, $12.5-21 \times 4-11$ $\mathrm{mm}$, margin sometimes involute, apex attenuate or acuminate with a spinulose tip; lateral lobes linearlanceolate, 6.5 - $10 \mathrm{~mm}$ long. Corolla 26 - $59 \mathrm{~mm}$ long, white, pale to bright blue or purple, pubescent mainly on lateral lobes externally; tube cylindrical, $11-30 \mathrm{~mm}$ long, curved; limb in weak " $4+1$ " configuration; abaxial lobe offset by $1-4.5 \mathrm{~mm}$; each lobe obovate or obovateelliptic, $12-25 \times 5-13 \mathrm{~mm}$, adaxial lobes sometimes narrowest, apices rounded or emarginate. Stamens inserted \pm midway along corolla tube; filaments 15 $33 \mathrm{~mm}$ long; anthers 2.4 - $4 \mathrm{~mm}$ long; lateral staminodes $0.8-2.5 \mathrm{~mm}$ long, pubescent, antherodes 0.5 - $1.3 \mathrm{~mm}$ long. Ovary glabrous; style puberulous towards base; stigma linear, $0.8-2.2 \mathrm{~mm}$ long. Capsule 10 - 16 mm long, shortly beaked, glabrous; seeds 5.5 $9.5 \times 4-6.5 \mathrm{~mm}$.

Barleria taitensis S.Moore subsp. occidentalis (S.Moore) I.Darbysh. stat. nov.

http:/ /www.ipni.org/urn:lsid:ipni.org:names:77215736-1

三 Barleria taitensis S.Moore var. occidentalis S.Moore, J. Bot. 40: 344 (1902b); Makholela (2008: 22); Darbyshire et al. (2012: 766); Klaassen \& Kwembeya (2013: 130). Type: Angola, Libongo, fl. \& fr. Sept. 1858, Welwitsch 5119 (lectotype BM! [BM000931085], selected here; isolectotypes K! [K000430895], LISU! [LISU223412]).

Barleria sp. nov. aff. B. salicifoliae sensu Moore (1880: 270), pro parte quoad Welwitsch 5119.

Barleria salicifolia sensu auctt., non S.Moore (1880: 268): Clarke (1899: 162), pro parte quoad Welwitsch 5119; Hiern (1900: 817), pro parte quoad Welwitsch 5119.

Barleria stellato-tomentosa sensu Benoist (1950: 18), non S.Moore.

Barleria rogersii sensu auctt., non S.Moore: Meyer (1957: 385; 1968: 17); Craven (1999: 152); Welman (2003: 94), pro parte.

Anterior calyx lobe subrhombic or rounded, $11.5-17 \mathrm{~mm}$ long, apex bifid with widely divergent spinulose tips $1.5-$ $6 \mathrm{~mm}$ long; external surface with conspicuous buff or yellow long-armed stellate hairs along veins and margin, those along margin with or without bulbous bases; posterior calyx lobe with attenuate apex. Corolla blue or purple, $26-40.5 \mathrm{~mm}$ long, including tube $11-17.5 \mathrm{~mm}$ long. Capsule 11.5 - 13.5 mm long. Fig. 13. 

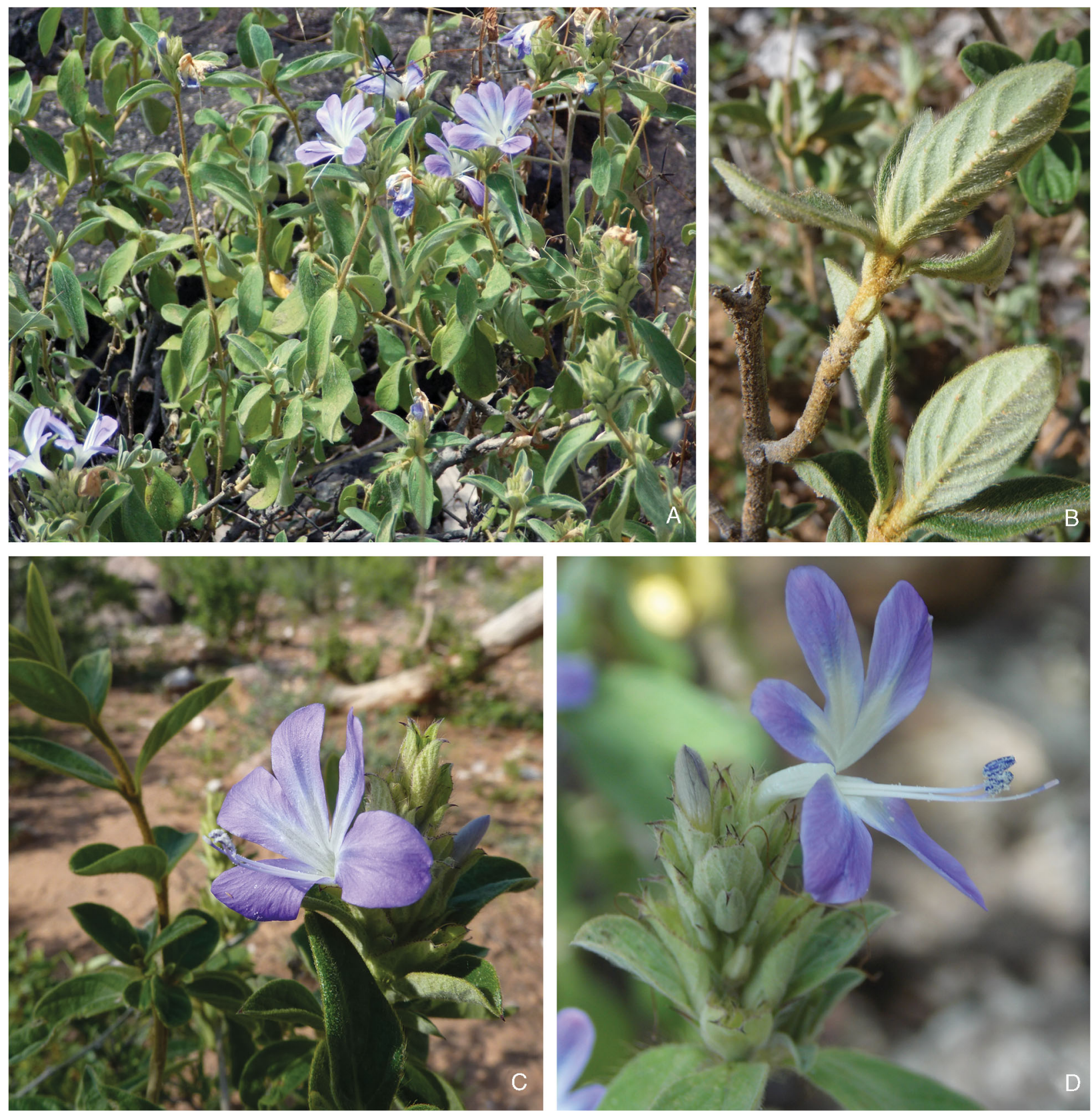

Fig. 13. Barleria taitensis subsp. occidentalis. A habit; B stem and leaves (collected as Tripp \& Dexter 847); C \& D inflorescences (C collected as Tripp et al. 4074). PHOtos: A, D F. M. P. GONÇALVES, ANGOLA; B, C E. A. MANZITTO-TRIPP, NAMIBIA.

DISTRIBUTION. This subspecies is known only from western Angola (Bengo, Benguela, Cuanza Sul, Cunene, Huíla and Namibe Provs.) and northwestern Namibia (Kunene Region); Map 9.

ADDITIONAL COLLECTIONS STUDIED. ANGOLA. Without precise locality, fl. 1908 - 1909, Pearson 2828 (K!); between Jambos Fort and Mission Station, fl. 15 May 1909, Pearson 2531 (K!); between Jambos Mission Station and Cahama, fl. 17 May 1909, Pearson 2469 (K!); km 82.5 on the Benguela - Katanga railway, fl. 11 June 1909, Pearson 2123 (K!); Roçados, fl. \& fr. July 1936, Boss in TRV 35947 (PRE!); entre
Moçâmedes et Villa Arriaga [Bibala], fl. Aug. 1937, Humbert 16512 (BM!, K!, P); Moçâmedes, Gargante, fl. May 1937, Gossweiler 10841 (BM!, K!, US!); Vila Arriaga [Bibala], base of Serra de Chela, fl. 18 May 1937, Exell Ẽ Mendonça 2085 (BM!); Moçâmedes - Camucuio, fl. 26 April 1938, d'Abreu 88 (BM!); Vila Arriaga [Bibala], fl. \& fr. 14 Aug. 1941, Gossweiler 13187 (LISC!, LUBA!); Benguela, Coporolo, Rio Coporolo, fl. 24 June 1955, Correia 752 (LUBA!); Moçâmedes, Maconje, st. 5 March 1956, Teixeira 704 (PRE!); Moçâmedes, Lungo, fl. May 1956, Teixeira 1132 (LUBA!, PRE!); Moçâmedes, Capangombe, fl. June 1956, Teixeira 


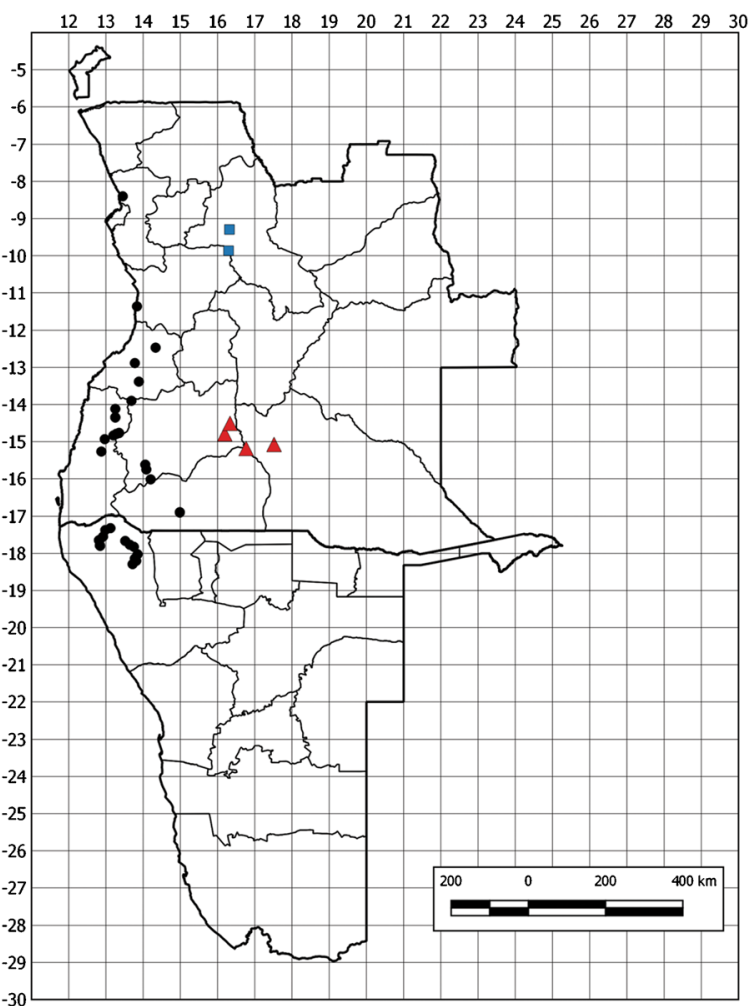

Map 9. Distribution of Barleria taitensis subsp. occidentalis (black circles), B. salicifolia (blue squares) and B. buddleioides (red triangles).

1352 (LUBA!, PRE!); Moçâmedes, a $10 \mathrm{~km}$ do Rio da Areia, fl. 21 May 1957, Teixeira 2378 (PRE!); Moçâmedes, prox. de Vila Arriaga [Bibala], fl. 15

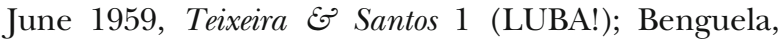
Coporolo, a $2 \mathrm{~km}$ desta localidade a caminho para Benguela, fl. 19 April 1960, Barbosa Eै Correia 9135 (BM!, K!); Moçâmedes, Bibala, Cacanda, fl. 7 May 1960, Mendes 4027 (LUBA!); Sá da Bandeira [Lubango], prox. do R. Impulo, fl. 31 May 1960, Pereira 105 (LUBA!); Moçâmedes, Vila Arriaga [Bibala], Cacanda, a $6 \mathrm{~km}$ para Munhino, fl. 17 May 1962, Correia 1998 (LUBA!); Moçâmedes, Bibala, Lungo, picada para o Buaiepo (13.5 km do Lungo), fr. 13 Oct. 1962, Henriques E $\mathcal{F}^{2}$ Moreno 6 (BM!, LUBA!, SRGH!); Novo Redondo [Sumbe] - Lobito, km 27, fl. 31 March 1973, Bamps E Martins 4351 (BR, K!, LISC!, WAG!); camp 2 between Lubango and Bibala, fl. 10 April 2017, Tripp E $\mathcal{F}^{2}$ Dexter 6913 (COLO!, K!); Bibala, a $25 \mathrm{~km}$ de Camucuio, fl. \& fr., without date, Teixeira 546 (BM!). NAMIBIA. Kaokoveld, fl. 1955 - 1956, von Koehnen 20 (M!); Kaokoveld, 3.5 miles N of Ohopoho, fl. 29 March 1957, de Winter E Leistner 5262 (K!, M!, PRE, WIND!); 7 miles SW of Ohopoho, fl. 20 April 1957, de Winter Eं Leistner 5576 (K!, M!, PRE, WIND!); Kaokoveld, track Ohopoho - Kaoko Otavi, 10 miles from Ohopoho, fl. 6 June 1963, Kers 1247 (WIND!); track Kaoko Otavi - Ohopoho, 4 miles from K.O., fl. 12 June 1963, Kers 1444 (WIND!); 10 meilen N
Etengua, fl. 17 June 1965, Giess 9002 (LISC!, M!, PRE, WIND!); 5 miles N Okandungu, fl. 15 April 1966, Giess 9315 (LISC!, M!, WIND!); 21 miles N Ohopoho auf der strasse nach Epembe, fl. \& fr. 4 July 1969, Meyer 1226 (M!, WIND!); $16 \mathrm{~km} \mathrm{~S} \mathrm{Epembe,} \mathrm{fl.} 21$ March 1974, Merxmüller Eॄ Giess 30442 (K!, M!, WAG!, WIND!); Etanga Region, old infl. 15 Feb. 1998, Burke 9828 (WIND!); Okakora Mts, fl. 31 March 2003, Burke 3034 (WIND!); Opuwo Distr., $1.3 \mathrm{~km}$ W of Otjitanda towards Van Zyl's Pass, fl. 6 May 2005, Kolberg et al. 1555 (WIND!); along $4 \times 4$ track E of Van Zyl pass, E of Etanga, fl. 25 March 2010, Tripp Eं Dexter 847 (K!, RSA, WIND); $22.1 \mathrm{~km}$ S of Etengwa towards Otjihanda, old infl. 16 Jan. 2013, Tripp et al. 4071 (K!, RSA, WIND); $14.2 \mathrm{~km} \mathrm{~W}$ of turnoff to Oropembe from road between Etengwa and Otjihanda, fl. 16 Jan. 2013, Tripp et al. 4074 (K!, RSA, WIND).

HABITAT \& ECOLOGY. Subsp. occidentalis occurs in woodland and wooded grassland, often dominated by Colophospermum mopane, open rocky slopes, river fringes, roadsides and on eroded soils; at 150 - 1325 $\mathrm{m}$ elevation. Its distribution coincides largely with the South-West Angola biogeographical region of Linder et al. (2012). In Namibia, it occurs in the Western Highlands Acacia Tree-and-shrub Savanna vegetation type of Mendelsohn et al. (2002).

CONSERVATION STATUS. This subspecies is locally common or even dominant in the understory of dry woodland or in open scrub. It has an EOO of 144,000 $\mathrm{km}^{2}$ based on known occurrence data and is known from numerous locations. In some areas, such as around Opuwo in Namibia, there may have been population declines due to over-grazing by domestic livestock in the mopane woodlands which has resulted in the ground vegetation layer being heavily denuded. However, it does not appear to be globally threatened and is assessed as of Least Concern - LC.

NOTES. Barleria taitensis has a scattered distribution across the dry woodlands and bushlands of tropical Africa and displays considerable regional variation. Three geographically disjunct subspecies are recognisable based upon differences in corolla shape and size and calyx characteristics: subsp. taitensis, subsp. occidentalis and subsp. rogersii (S.Moore) I.Darbysh. (see Table 2, key below and further notes in Darbyshire 2015: 87). Barleria rogersii was originally separated from $B$. taitensis by Moore (1918: 38) on the basis of having "quite different flowers", yet the corolla shape is very close to that of Moore's (1902b) var. occidentalis (here promoted to subspecies status). The two are, nevertheless, easy to separate as plants of subsp. rogersii have ovate anterior calyx lobes with usually closely parallel, not divergent, spine tips (see Darbyshire et al. 2019b, fig. 2N), and they always have a finer and paler calyx indumentum.

Plants from central and southern Tanzania (Flora of Tropical East Africa regions T5 and T7) appear very close to subsp. occidentalis, particularly some Namibian populations which share the bulbous based marginal 
hairs and prominent apical spines of the outer calyx lobes. The only difference of note appears to be that the Tanzanian plants have larger capsules, but very few mature capsules have been seen for this species as a whole so that the range of variation may not be truly reflected in Table 2. The additional differences listed in Flora of Tropical East Africa (Darbyshire 2010: 381) do not hold up on closer inspection of subsp. occidentalis - the Namibian populations had not been studied at the time of that account. The $\mathrm{T} 5 / 7$ populations are included in Table 2 as a provisional fourth taxon. A key to the four taxa is provided below.
Welwitsch's type locality for subsp. occidentalis is rather a long way further north than the other known localities for this taxon and it has not to our knowledge been recollected from Bengo Province despite extensive collecting in the Luanda area. It is just possible that the locality notes on the Welwitsch specimen are incorrect, given that Welwitsch did not use a consecutive numbering system in the field (see Albuquerque \& Correia 2009; Albuquerque et al. 2009), and that it was actually collected from his 1859 expedition inland from Moçâmedes.

\section{Key to subspecies of Barleria taitensis}

1 Corolla white or pale blue, more rarely bright blue; tube usually over $17 \mathrm{~mm}$ long, longer than or equal to the

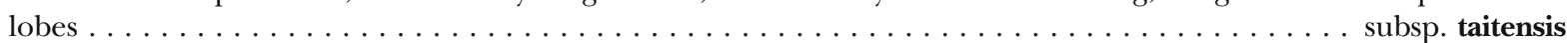

Corolla bright blue or purple, rarely pale; tube $10.5-17.5 \mathrm{~mm}$ long, shorter than or equal to the lobes . . 2

2 Bracteoles and outer calyx lobes with prominent bulbous-based hairs along margins . . . . . . . . . . . 3

Bracteoles and outer calyx lobes lacking prominent bulbous-based hairs; calyx margin often tightly involute . . . . 4

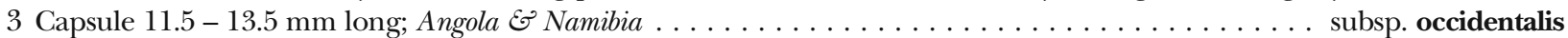

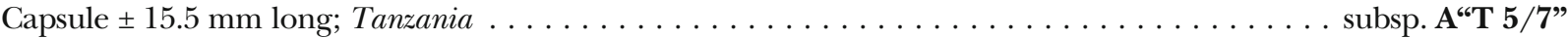

4 Anterior calyx lobe ovate (-rounded), apex minutely notched with paired spinulose tips usually closely parallel, rarely divergent; surface with dense fine pale grey-buff stellate hairs; long-armed hairs on veins and margin pale and

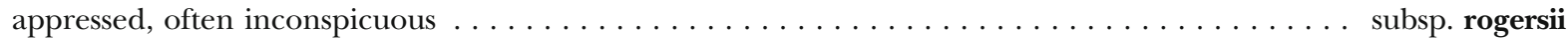

Anterior calyx lobe broadly sub-rhombic or rounded, apex more clearly notched or truncate with paired spinulose or apiculate tips \pm widely divergent; surface with buff or yellow long-armed hairs numerous and

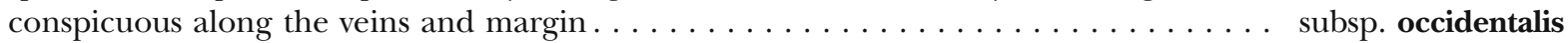

58. Barleria salicifolia S.Moore (1880: 268); Clarke (1899: 162), pro parte; Hiern (1900: 817), pro parte excl. Welwitsch 5119; Klopper et al. (2006: 5), excl. syn.; Makholela (2008: 22). Type: Angola, Pungo Andongo ad Lombe [and] Candumba, fl. 1857, Welwitsch 5102 (lectotype BM! [BM000896256, selected here; isolectotypes LISU! [LISU223413, LISU223414]). Additional syntype: Angola, Pungo Andongo, Quibinda [and] Condo, in bud, 1857, Welwitsch 5103 (BM! [BM000896255]).

Suffruticose herb with erect stems from a woody rootstock, to $75 \mathrm{~cm}$ tall; stems at first densely covered in mixed golden-brown and whitish dendritic hairs, the latter with long, wispy ascending arms, later glabrescent. Leaves on petiole to $10 \mathrm{~mm}$ long or distal leaves subsessile; blade discolourous, drying dark brown above, pale grey beneath, markedly heterophyllous, basal-most leaves elliptic, to $11.5 \times 5 \mathrm{~cm}$ (l:w ratio $2.3-3.4: 1$ ), gradually narrowing up the stem, upper leaves linear-lanceolate, $9.5-13 \times 1.2-2.1 \mathrm{~cm}$ (l:w ratio 6.2 - 7.9: 1), base cuneate, margin entire, apex acute, upper surface at first with white stellate hairs but soon glabrescent, lower surface with dense wispy white stellate hairs throughout; lateral veins $5-6$ pairs, slightly impressed above, these and reticulate tertiary veins prominent beneath. Inflorescences termi- nal on main and short lateral branches, capitate, to c. $2.5 \mathrm{~cm}$ in diam.; outermost bracts ovate to ovateelliptic, $20-24 \times 11-14 \mathrm{~mm}$, base rounded to obtuse, apex attenuate to obtuse, external surface with dense white stellate hairs at least when young, many hairs with a long wispy arm, hairs along midrib sometimes golden, these more persistent, pinnate-reticulate venation prominent; bracteoles held erect and clasping the calyx, brown and somewhat scarious, obovate to oblanceolate, $20-22 \times 3.5-7 \mathrm{~mm}$, with pale-buff long-armed stellate hairs along margin and midrib, sparse elsewhere. Calyx drying brown, somewhat scarious; abaxial lobe oblong-elliptic, c. $19 \times 9 \mathrm{~mm}$, base cuneate, margin entire, apex with two bluntly triangular lobes c. $1.5-2 \mathrm{~mm}$ long, external surface with dense long ascending golden hairs, mostly simple but some along margin and towards apex with a stellate base; posterior lobe elliptic, c. $17.5 \times 7 \mathrm{~mm}$, apex attenuate, external surface with long golden hairs largely restricted to margin; lateral lobes linearlanceolate, c. $11.5 \mathrm{~mm}$ long. Corolla colour unknown, c. $32 \mathrm{~mm}$ long, glabrous externally; tube c. $16 \mathrm{~mm}$ long, cylindrical but broadening somewhat towards mouth; lobes obovate, c. 13 - 15.5 mm long. Stamens inserted c. $7 \mathrm{~mm}$ from base of corolla tube; filaments $8.5-9.5 \mathrm{~mm}$ long, pubescent in proximal half; anthers shortly exserted, $3 \mathrm{~mm}$ long; lateral staminodes 1.2 - 


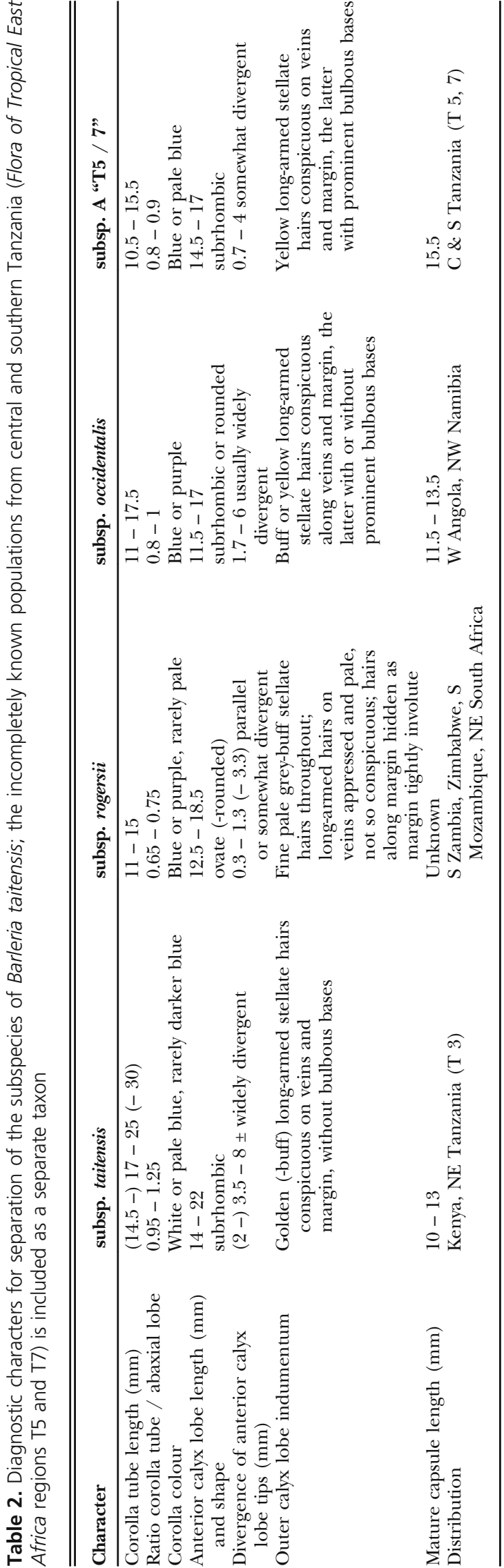

$1.4 \mathrm{~mm}$ long, pubescent, antherodes vestigial, c. $0.3 \mathrm{~mm}$ long. Pistil and capsule not seen.

DISTRIBUTION. This species is endemic to northern Angola (Malanje Prov.); Map 9.

HABITAT \& ECOLOGY. The habitat for this species was not recorded by Welwitsch.

CONSERVATION STATUS. This species is known only from the two syntype collections from 1857, when Welwitsch recorded it from two areas in the river valleys of Malanje Province. This area of Angola has not been well botanised since the early expeditions of Welwitsch, hence the full range and abundance of this species is not known. Further, the exact localities of these collections have not been pinpointed and the habitat for this species is not known. Therefore, a full threat assessment is not possible and it must currently be assessed as Data Deficient - DD, although there has certainly been some extensive habitat modification within its range as evidenced by Google Earth imagery.

NOTES. The wispy white stellate indumentum of the abaxial surface of the leaves and young bracts, contrasting markedly with the long golden, predominantly simple hairs on the calyces, are highly distinctive in this species, as is the marked heterophylly, with the distal leaf pairs being linear-lanceolate.

59. Barleria stellato-tomentosa S.Moore (1880: 268); Clarke (1899: 161); Hiern (1900: 816); Benoist (1950: 18); Klopper et al. (2006: 4); Makholela (2008: 22). Type: Angola, Pungo Andongo, prope Lombe, fl. March 1857, Welwitsch 5165 (lectotype BM! [BM000931110], selected here; isolectotypes K! [K000394508], LISU! [LISU223410]). Additional syntype: Angola, Pungo Andongo, in bud, without date, Welwitsch 5095 (BM! [BM000896254], K! [K000394509], LISU! [LISU223411]).

Suffruticose herb with few - several erect stems from a woody rootstock, $30-70 \mathrm{~cm}$ tall; stems covered in golden-brown dendritic hairs, these either elongate and with only a short arm or more squat and with a long ascending arm. Leaves subsessile or petiole to $9 \mathrm{~mm}$ long; blade discolourous, dark above where usually drying dark grey-brown, pale green beneath, somewhat heterophyllous, blades towards stem base elliptic, $5.7-8.8 \times 2.4-3.8 \mathrm{~cm}$ (1:w ratio $1.8-2.4: 1$ ), those in upper portion of stems narrowly oblongelliptic, lanceolate or somewhat oblanceolate, $4.2-7.6$ $\times 1-2.4 \mathrm{~cm}$ (l:w ratio $2.7-4.9$ : 1 ), base cuneate or obtuse, margin entire, apex acute to rounded, apiculate, upper surface with short- to long-armed stellate hairs, at first numerous but can be caducous, lower surface with numerous short- to long-armed stellate hairs throughout at least when young and with short 
dendritic hairs especially along main veins and margin, hairs at first golden-brown, stellate hairs becoming paler buff-coloured with maturity; lateral veins $4-6$ pairs, slightly impressed above, these and reticulate tertiary veins prominent beneath. Inflorescences terminal, subglobose, $2-3 \mathrm{~cm}$ in diam., sessile and subtended by reduced leaves; bracts and bracteoles with markedly purple distal portion, contrasting with pale base and veins, outermost bracts broadly ovate to suborbicular, $11.5-22 \times 10-17.5 \mathrm{~mm}$, base rounded, apex rounded to acute, external surface with sparse to more dense golden-brown dendritic hairs and with prominent pinnate-reticulate venation; bracts within the head becoming scarious and gradually reducing in size and width, resembling bracteoles; bracteoles held erect, scarious, obovate to oblanceolate, $16-23 \times 1.5-8.5 \mathrm{~mm}$, midrib and margin often with dense long-armed stellate to dendritic hairs. Calyx scarious, drying pale brown with darker purple apices or purple restricted to apical margin; anterior lobe oblong-obovate, $14-16.5 \times 7-7.5 \mathrm{~mm}$, base cuneateattenuate, margin entire except for bulbous bases of marginal hairs, apex with two broadly triangular lobes $1.2-5.5 \mathrm{~mm}$ long, external surface with dense pale buff-coloured long-armed stellate hairs throughout; posterior lobe as anterior lobe but obovate-rhombic to oblong-obovate, apex acute; lateral lobes linear-lanceolate, $7.5-12.5 \mathrm{~mm}$ long, golden-sericeous, only those hairs along midrib with a stellate or dendritic base. Corolla violet-blue or white (see note), $34-39 \mathrm{~mm}$ long, with stellate hairs towards apex of lateral lobes externally or these sparse; tube $19-23.5 \mathrm{~mm}$ long, cylindrical; limb subregular; lobes broadly obovate c. $13.5-18 \mathrm{~mm}$ long, apices rounded. Stamens inserted in proximal half of corolla tube; filaments c. $12 \mathrm{~mm}$ long, pubescent proximally; anthers shortly exserted, c. $3.5 \mathrm{~mm}$ long; lateral staminodes c. $2 \mathrm{~mm}$ long, pubescent, antherodes $0.4 \mathrm{~mm}$ long. Pistil glabrous except for dense tuft of minute papillose hairs at attachment point of style; stigma linear, c. $1.2 \mathrm{~mm}$ long. Capsule and seeds not seen.

DISTRIBUTION. This species is endemic to northern Angola (Cuanza Sul and Malanje Provs.); Map 10.

ADDITIONAL COLLECTION STUDIED. ANGOLA. Cuanza Sul, Mussende, prox. R. Cuanza, fl. Aug. 1930, Gossweiler 9290 (BM!, K!); Malanje, Quimbango, margens do R. Quimbango, fl. 10 June 1970, Barbosa et al. 12020 (LISC!).

HABITAT \& ECOLOGY. Barleria stellato-tomentosa is recorded from miombo (Isoberlinia angolensis (Welw. ex Benth.) Hoyle \& Brenan) woodland, open thickets on clay soils and at the ecotone between riverine forest/woodland and wooded grassland, at $900-1000$ m elevation.

CONSERVATION STATUS. Based upon current knowledge, this species has a highly restricted range with an EOO of 16,405 $\mathrm{km}^{2}$, and is known from only four localities. The southeastern locality at Quimbango is within the Luando Integral Nature Reserve, an area of $8,280 \mathrm{~km}^{2}$ designated in 1955 in order to protect the giant sable antelope, the national symbol of Angola. This Reserve was effectively managed for the antelope prior to the Angolan civil war, but active conservation ceased during the war and game poaching has become a major problem (Vaz Pinto 2019). The park has a sizable human population, estimated at 18,000 in 1971 (Vaz Pinto 2019), and the area around Quimbango has been impacted by agricultural activity, but there is still extensive natural habitat away from this town. The other three collecting localities are historical and are not within protected areas. Of these, the Lombe area has been most heavily transformed, with extensive agricultural activity and settlement. Based upon curent data, it is provisionally assessed as Vulnerable - VU B1ab(iii). However, botanical exploration within this species' range is incomplete, and more information on its the current range, abundance and threats are desirable.

NOTES. Barleria stellato-tomentosa and B. subglobosa (species 60 below) are doubtless closely related and may prove to be conspecific once further material becomes available but are kept separate here based on the limited material currently to hand. In the dry state, they are easily separated by the differing bract coloration, with $B$. stellato-tomentosa having conspicuous dark purple apices to the bracts giving the whole

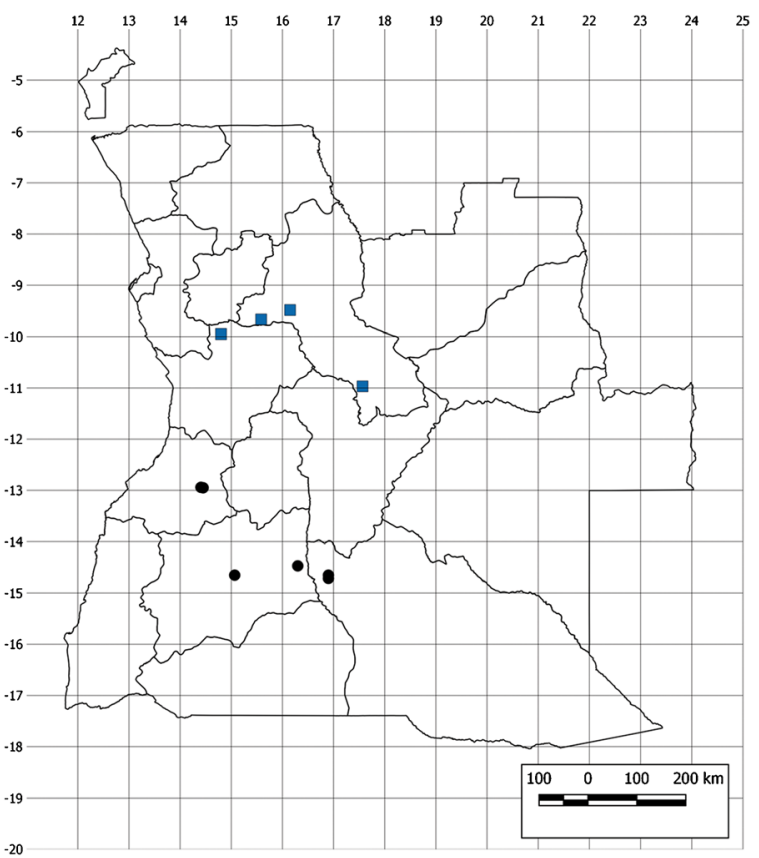

Map 10. Distribution of Barleria stellato-tomentosa (blue squares) and $B$. subglobosa (black circles). 
inflorescences a dark appearance whilst in B. subglobosa the inflorescence is golden-brown or golden-green in the dry state. That said, Barbosa et al. (12020) has less markedly coloured bracts than the other material of B. stellato-tomentosa. The distributions of these two species are separated by the central highlands of Angola.

On Gossweiler 9290, the corolla is recorded as being "ochra [sic.] yellow", but F. Welwitsch (his 5165) recorded the flowers as violet-blue, a more usual colour for species in sect. Stellatohirta. The flowers on Gossweiler 9290 are small and some are withered - it is possible that the colour description is based on withered corollas that can take on an orange-brown hue.

60. Barleria subglobosa S.Moore (1911: 307; 1930: 135); Klopper et al. (2006: 5); Makholela (2008: 22). Type: Angola, near Forte Conselheiro Borgia, at Cutchi, fl. \& fr. 4 May 1906, Gossweiler 3139 (holotype BM! [BM000896252]; isotypes BR* [BR0000006915124], ?K! [K001009573] — see note).

Suffruticose herb or subshrub, sometimes rhizomotous, with few - several erect stems from a woody rootstock, $20-90 \mathrm{~cm}$ tall; stems densely covered in golden-brown long-armed dendritic hairs, the arm ascending, and interspersed paler stellate hairs. Leaves on petiole 4 $18 \mathrm{~mm}$ long; blade discolourous, dark above where usually drying dark brown, pale green beneath, somewhat heterophyllous, most leaves narrowly oblong-elliptic or lanceolate, $6-10.8 \times 1.7-3.5 \mathrm{~cm}$ (1:w ratio 3.1 - 5.2: 1) but basal-most leaves more elliptic, shorter and with 1:w ratio typically 2: 1, base cuneate, margin entire, apex acute or obtuse, upper surface with long-armed stellate hairs, at first numerous but can eventually be caducous, lower surface with numerous long-armed stellate to dendritic hairs throughout at least when young and persisting along main veins and margin, hairs at first golden-brown, the stellate hairs becoming paler buff-coloured with maturity; lateral veins $5-7$ pairs, slightly impressed above, these and reticulate tertiary veins prominent beneath. Inflorescences terminal, subglobose or becoming conical in fruit, $2-4.5 \times 2-3.7 \mathrm{~cm}$; outermost bracts ovate to suborbicular, $15-29 \times 8-22 \mathrm{~mm}$, base rounded, apex rounded to acute, external surface with dense goldenbrown dendritic hairs and with prominent pinnatereticulate venation; bracts within the head gradually reducing in size and width, resembling bracteoles; bracteoles held erect and clasping the calyx, obovate to oblanceolate, $17-23 \times 4-9.5 \mathrm{~mm}$, margins often with bulbous based dendritic hairs. Calyx drying pale brown with darker green-brown or pinkish apices, somewhat accrescent; abaxial lobe oblong-obovate, 15.5-22.5 ×6$11 \mathrm{~mm}$, base cuneate-attenuate, margin entire, apex with two broadly triangular lobes $2.5-8.5 \mathrm{~mm}$ long, external surface with numerous golden-brown long-armed dendritic hairs especially along veins and margin, sometimes sparse towards base, palmate main veins prominent; posterior lobe as anterior lobe but elliptic-rhombic to obovate-rhombic, apex acute, external surface often with hairs restricted to margin and apex; lateral lobes linearlanceolate, 12 - $14.5 \mathrm{~mm}$ long, held tightly against pistil, golden-sericeous, only those hairs along midrib with a dendritic base. Corolla blue, purple or lilac, $28-39 \mathrm{~mm}$ long, glabrous externally or with very few hairs at apex of lateral lobes; tube 17 - $21.5 \mathrm{~mm}$ long, cylindrical or somewhat broadened towards mouth; limb subregular; lobes broadly obovate, abaxial and lateral lobes c. $12-17$ $\times(6-) 9-11.5 \mathrm{~mm}$, apices rounded; adaxial lobes marginally narrower. Stamens inserted c. 10 $11 \mathrm{~mm}$ from base of corolla tube; filaments 11 $14 \mathrm{~mm}$ long, pubescent in proximal half; anthers shortly exserted, 2.5 - $2.8 \mathrm{~mm}$ long; lateral staminodes $1.2-1.6 \mathrm{~mm}$ long, pilose, antherodes vestigial, to $0.2 \mathrm{~mm}$ long. Pistil glabrous except for dense tuft of minute crisped pale hairs at attachment point of style; stigma linear, $1.9-2.5 \mathrm{~mm}$ long. Capsule 13.5 - $14.5 \mathrm{~mm}$ long including beak $1.5-2.5 \mathrm{~mm}$, glabrous; seeds $7-7.5 \times 5.5-6.2$ $\mathrm{mm}$.

DISTRIBUTION. This species is endemic to southwestern Angola (Benguela, Cuando Cubango and Huíla Provs.); Map 10.

ADDITIONAL COLLECTIONS STUDIED. ANGOLA. Benguela, Cubal, Capacca (Membassoco), fl. \& fr. April 1941, Faulkner A.405 (BM!, K!, PRE!); Menongue, andados c. $7 \mathrm{~km}$ de Cuchi para Lievera, fl. 1 April 1960, Mendes 3371 (K!, LISC!, LUBA!); Huíla, Ganguelas, Vila Artur de Paiva [Kuvango], vale do Cubango, fl. 7 April 1960, Mendes 3471 (K!, LISC!); Huíla, Capelongo, Lusseque, fl. 19 June 1965, de Menezes 1683 (LUBA!); Benguela, alto da Capaca, na estrada Cubal-Ganda, fl. May 1970, Amaral 27 (LUBA!).

HABITAT \& ECOLOGY. Barleria subglobosa is recorded from dry miombo (Julbernardia) woodland and from bushland on sandy soils, at 1000 - 1450 m elevation.

CONSERVATION STATUS. Based upon current evidence, this species has a highly restricted range in southwestern Angola with an EOO $19,753 \mathrm{~km}^{2}$. None of its known localities are protected, and extensive areas within its EOO have been highly impacted by dense settlement and agricultural activities. Indeed, northern Huíla and northwestern Cuando Cubango Provinces experienced some of the highest rates and most widespread loss of "forest cover" in Angola between 2000 and 2015 (Mendelsohn 2019, Figs 8.1 and 8.8). With regard to the four known locations for this species, the area of Capacca (Capaca) near Cubal is intensively farmed except for the steep slopes of the large inselberg to the north of the Cubal - Ganda road. Similarly, the locations at Cuchi and Capelongo 
are now transformed by settlement and agriculture. With a continuing decline in quality and extent of habitat, it is provisionally assessed as Vulnerable - VU Blab(iii). However, parts of this species' range have been unexplored botanically away from the few main transport routes, and more information on the range and abundance of this species is desirable.

NOTES. There is very limited flowering material of this species available; most of the floral measurements are based on the two Mendes collections but the lower size ranges for the lobes are based on Moore's (1911) description in the protologue.

There is a specimen of Barleria subglobosa at $\mathrm{K}$ collected by John Gossweiler, labelled as Gossweiler 3131, but lacking any further collecting details. We consider it likely that this is a mis-numbered duplicate of the type specimen (Gossweiler 3139).

61. Barleria buddleoides S.Moore (1902c: 307; 1930: 135); Balarin et al. (1999: 178, 196); Klopper et al. (2006: 3); Makholela (2008: 21). Type: Angola, between Kassinga and Kubango, fl. 6 Oct. 1899, Baum 238 (holotype BM! [BM000931099]; isotypes $\mathrm{BR}^{*}$ [BR0000005106554], E*, ?K! [K000913673] — see note, M! [M0109643]).

Barleria salicifolia sensu Balkwill \& Balkwill (1998: fig. 12b).

Suffruticose herb or subshrub, $45-90 \mathrm{~cm}$ tall with erect or ascending stems from a woody rootstock; stems densely covered in short golden dendritic hairs, some with a short antrorse arm. Leaves subsessile or on petiole to $6 \mathrm{~mm}$ long; blade coriaceous, markedly discolourous, drying brown to green above, pale yellow-cream beneath, narrowly oblong, oblong-elliptic or somewhat oblanceolate, $4.3-7.5 \times 0.9-2 \mathrm{~cm}$ (l:w ratio $3.4-6.3$ : 1 ), base cuneate, margin entire, apex acute to rounded, upper surface at first with wispy white stellate hairs but soon glabrescent, lower surface entirely covered by white to cream-yellow stellate or shortly dendritic hairs, those on main veins can be brighter yellow and often long-armed; lateral veins $5-7$ pairs, these and reticulate tertiary veins \pm prominent beneath. Inflorescences terminal on main and short lateral branches, subglobose or somewhat conical, $1.5-4 \mathrm{~cm}$ in diam.; bracts and bracteoles brown-scarious, outermost bracts broadly ovate to elliptic-obovate, $9-25$ $\times 7-22 \mathrm{~mm}$, base rounded or subcordate to acute, apex obtuse to acute, external surface with pale-buff to yellow stellate hairs mainly along midrib and towards margins and apex, hairs with or without a long arm, pinnatereticulate venation prominent; bracteoles obovate to oblanceolate, $11-26.5 \times 3-11 \mathrm{~mm}$, with numerous long-armed stellate hairs thoughout, hairs pale-buff to golden-yellow or sometimes mixed. Calyx at first pale green with purplish apices but soon brown-scarious; abaxial lobe oblong-elliptic, oblong-lanceolate or oblong-obovate, $12.5-25 \times 5.5-9 \mathrm{~mm}$, base cuneate, margin entire except for bulbous-based hairs forming minute teeth, apex with two triangular lobes 2.7 $3.5 \mathrm{~mm}$ long, external surface with numerous longarmed stellate hairs, these golden to whitish, sometimes mixed with whitish hairs towards base and/or margin; posterior lobe as anterior lobe but can be slightly longer, to $27.5 \mathrm{~mm}$ long, apex acute to attenuate; lateral lobes linear-lanceolate, 10 $16 \mathrm{~mm}$ long. Corolla white or cream-coloured, 40 $70 \mathrm{~mm}$ long, glabrous externally or with very few stellate hairs on lateral lobes; tube $24-36.5 \mathrm{~mm}$ long, cylindrical but broadening towards mouth, curved; limb in " $4+1$ " configuration, abaxial lobe offset by $2.5-5 \mathrm{~mm}$, obovate or elliptic, c. $12-26$ $\times 8.5$ - $20 \mathrm{~mm}$, apex emarginate or rounded; lateral lobes obovate-orbicular, c. $12-28 \times 12-25$ $\mathrm{mm}$, apices emarginate; adaxial lobes somewhat narrower. Stamens inserted in proximal half of corolla tube; filaments c. $24-30 \mathrm{~mm}$ long; anthers exserted, 4.7 - $5.7 \mathrm{~mm}$ long; staminodes not seen. Pistil glabrous; stigma linear, 1.7 - $2.5 \mathrm{~mm}$ long. Capsule not seen.

DISTRIBUTION. This species is endemic to southern Angola (Cuando Cubango, Cunene and Huíla Provs.); Map 9.

COLLECTIONS STUDIED. ANGOLA. Between Catoco and Cavange, fl. 27 Aug. 1905, Gossweiler 1892 (BM!, LISC!); between Menongue and Cuelei, fl. Aug. 1925, Pocock 604 (PRE!); Huíla, Cassinga, Peco, c. 80 km N do Caiundo, na margem direita do R. Cubango, fl. 24 Sept. 1971, Santos Eे Barrosa 2961 (LISC!, LUAI!); [without data], ?de Menezes 3929 (LUBA!).

HABITAT \& ECOLOGY. Barleria buddleoides is recorded from miombo (Julbernardia) woodland and dry forest including open and secondary woodland, where it is associated with other suffruticose species, suggesting that it favours periodic burning; it occurs at c. $1400-$ $1550 \mathrm{~m}$ elevation.

CONSERVATION STATUS. This species is, to date, known only from a very small range in the area west of Menongue and around and to the south of Capelongo, with an EOO $4,613 \mathrm{~km}^{2}$. Despite its large, showy flowers, it has only rarely been collected and this species has not been recollected during recent surveys of the miombo woodlands of this region within the past decade, although these have been far from exhaustive. The northwestern part of its EOO in the vicinity of Capelongo has been highly impacted by intensive agricultural activity and settlement, with very little intact natural vegetation as evidenced by Google Earth imagery. A significant reduction in "forest cover" between 2000 and 2015 is evident in this area and particularly around Menongue (Mendelsohn 2019, Fig. 8.1). Intact miombo woodland is more extensive in the south and east of its range away from the few main transport routes. Based upon current evidence, this 
species is provisionally assessed as Endangered - EN Blab(iii), but with more information desirable on its current range and abundance.

NOTES. Barleria buddleioides is easily recognised by its distinctive foliage, the slender leaves being coriaceous and markedly discolorous, with the undersurface completely covered in a dense pale stellate indumentum whilst the upper surface is glabrescent. From the limited material seen, the inflorescence and corolla size appear to be variable and the inflorescence indumentum also varies in colour and hair length. Santos 2961 and ?de Menezes 3929 represent a small-flowered form (lower corolla measurements) with correspondingly small inflorescences which have more elliptic outermost bracts and rather short, oblong-obovate calyces. The other collections seen, including the type, have much larger corollas and correspondingly large inflorescences with broadly obovate outermost bracts and with elongate oblongelliptic or -lanceolate calyces. Two taxa may be involved but we consider it more likely that these are just two extremes of a range of variation within a single taxon.

There is a Baum specimen of this species at Kew which is likely to be an isotype but it lacks further data including a collection number.

\section{Excluded taxon}

Barleria macrolemma Peyr. (in Wawra \& Peyritsch 1860: 574). Type: Angola, Benguela, Wawra s.n. (?W, n.v.).

NOTES. The type specimen of this early name in Angolan Barleria has not been found. However, from the protologue description, we suspect that B. macrolemma may be a species of Petalidium. Peyritsch refers to his plant having conspicuous valvate, pale and slightly translucent bracts that enclose the flower which has a subequally 4-lobed calyx; he likens the bracts to the outer calyx lobes of typical Barleria. This could certainly apply to Petalidium, and the two genera are sometimes confused for this reason. Wawra's plant was mainly in fruit and there is very little description of the flowers, although Peyritsch does mention that it has four fertile stamens which would fit for Petalidium, as would the 2-seeded capsule which is ovate and shape and with a short stipe.

\section{Discussion}

Species richness and endemism of Barleria in Angola and Namibia

Excluding incompletely known taxa, sixty-seven taxa in 59 species of Barleria are recorded in Angola and Namibia (Table 3). Surprisingly, despite having a land border of $1,427 \mathrm{~km}$ with contiguous habitats and two shared phytochoria - the Kaokoveld Centre of Endemism and the Zambesian Regional Centre of Endemism - only seven taxa of Barleria (c. 10\%) are shared between the two countries. This can be attributed in part to under-collecting in southernmost Angola; for example, B. damarensis, B. lancifolia, $B$. lugardii and B. matopensis are all recorded from very near to the Angolan border in northern Namibia and are likely to extend into neighbouring Angola. However, this low level of overlap is also a reflection of the markedly high rates of local endemism in Barleria and conversely few truly widespread taxa (Balkwill \& Balkwill 1998; Darbyshire \& Luke 2016; Darbyshire et al. 2019a, 2019b). Rates of endemism or nearendemism (i.e., species that are largly confined to one country but just extend beyond the political border) for Barleria are high in Namibia, at nearly $50 \%$, and even more so in Angola, at over $70 \%$. If the two countries are combined, then three quarters of taxa of Barleria are entirely or largely restricted to this region (Table 3). Similarly high rates of endemism have been noted in other genera of Acanthaceae in the region, including Monechma Hochst. (Munday 1983, 1995; Darbyshire et al. 2020a), Petalidium (Tripp et al. 2017) and, in the border region of southern Namibia and the Northern Cape of South Africa, Acanthopsis Harv. (Steyn et al. 2019). Angola and Namibia are also home to two endemic genera of Acanthaceae, Dinteracanthus Schinz and Mcdadea E.Tripp \& I.Darbysh., both within the tribe Ruellieae (Tripp \& Darbyshire 2017, 2020).

An analysis of patterns of species richness of Barleria in Angola and Namibia (Fig. 14) is

Table 3. Summary of richness and endemism of taxa of Barleria (i.e., species, subspecies and varieties) in Angola and Namibia. Undescribed, incompletely known taxa are excluded

\begin{tabular}{lcccc}
\hline \hline Country & Species (Taxa) & Endemic Species (Taxa) & $\begin{array}{c}\text { Near-endemic } \\
\text { Species (Taxa) }\end{array}$ & $\begin{array}{c}\text { \% of taxa endemic (plus } \\
\text { near-endemic) }\end{array}$ \\
\hline Angola & $38(41)$ & $25(28)$ & $1(1)$ & $68.3 \%(70.7 \%)$ \\
Namibia & $28(33)$ & $9(13)$ & $3(3)$ & $39.4 \%(48.5 \%)$ \\
Angola + Namibia & $59(67)$ & $37(47)$ & $3(3)^{*}$ & $70.1 \%(74.6 \%)$ \\
\hline
\end{tabular}

*the total near-endemic taxa for Angola + Namibia is three rather than four, because B. meeuseana is near-endemic to Namibia but is endemic to Angola + Namibia. 


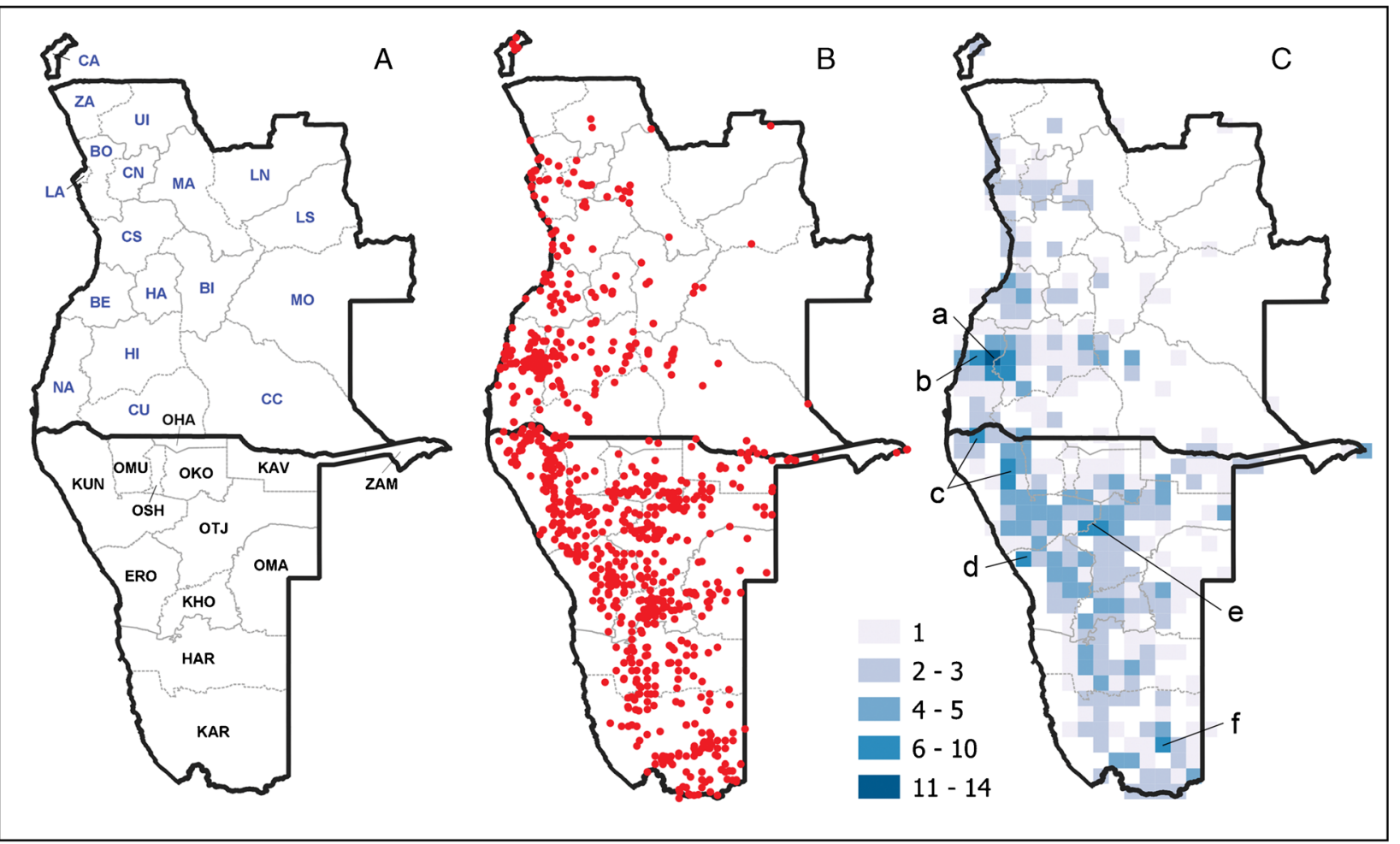

Fig. 14. Distribution of Barleria in Angola and Namibia. A Administrative regions of Angola and Namibia (see Table 4 for full names of Angolan Provinces and Namibian Regions); B georeferenced collections of Barleria seen by the authors (red circles); C taxon richness per half-degree-square for Barleria; squares with 6 or more taxa are highlighted, $a=$ Huila Plateau and Escarpment including Lubango Highlands, $b=$ Angolan Kaokoveld Desert, $c=$ Namibian Kaokoveld, $d=$ Brandberg and western vicinity, $e=$ Outjo-Otjiwarongo area, $f=$ southeast Karas region.

complicated by marked differences in collecting density between and within the two countries. Angola is, in general, much less thoroughly botanised than Namibia. In fact, it is the least intensively inventoried country in southern Africa for plants, with the north and east of the country being amongst the regions least well represented by botanical collections in continental Africa (Goyder et al. 2018; Goyder \& Gonçalves 2019). This undercollection is exacerbated in the study of Barleria by the loss of a significant portion of the historical Angolan Acanthaceae collections from both Angolan and Portuguese institutions during the civil war (see Introduction, Darbyshire et al. 2019a). Extant collections of Barleria in Angola are largely concentrated from the west, particularly along the coastal lowlands and on the Huíla Plateau in the vicinity of Lubango (Fig. 14B) where there has been much active botanical research.

\section{Angola}

Despite the limitations of under-collection and data gaps, some preliminary observations on the distributions of Barleria in Angola can be made. The deep aeolian Kalahari Sands that dominate the eastern half of the country (particularly Lunda Norte, Lunda Sul,
Moxico and Cuando Cubango Provinces - see Thomas \& Shaw 1991) are heavily leached and so of low fertility (Goyder \& Gonçalves 2019). This results in low species richness in most plant groups, particularly in those that favour a high soil nutrient content, including Acanthaceae (Darbyshire et al. 2020a). Hence, whilst this area is severely under-collected, it is very likely to host low diversity of Barleria, as our preliminary results suggest (Fig. 14C, Table 4). Only one endemic species of Barleria is known to occur in this area: the newly described $B$. thunbergiiflora. Goyder \& Gonçalves (2019) note a small but poorly understood endemic element to the flora of this region. In contrast, the more fertile soils of the central highlands and plateaus and the river valleys that drain them support a higher diversity of Barleria. Of particular note is the Huíla Plateau and Escarpment (a in Fig. 14C), a known centre of plant endemism (Exell \& Gonçalves 1973; Linder 2001; Figueiredo 2008). Huíla Province is noted as the administrative region with the highest taxon richness for Barleria (Table 4). The Lubango area is particularly noteworthy as the only half-degree-square to hold more than 10 Barleria taxa. The Lubango Highlands (Serra da Chela) potentially hold as many as 200 endemic plant species (Goyder \& Gonçalves 2019), and several endemic or range- 
Table 4. Numbers of taxa (species, subspecies and varieties) of Barleria per province of Angola and region of Namibia, including undescribed taxa. Province codes for Angola follow those used in Figueiredo \& Smith (2008)

\begin{tabular}{lclc}
\hline \hline $\begin{array}{l}\text { Province / Region (code } \\
\text { on Fig. 14) }\end{array}$ & Province / Region (code \\
on Fig. 14) & Number of taxa of Barleria \\
\hline Angola Provinces & 4 & Uíge (UI) & 2 \\
Bengo (BO) & 10 & Zaire (ZA) & 0 \\
Benguela (BE) & 3 & Namibia Regions & \\
Bié (BI) & 3 & Erongo (ERO) & 9 \\
Cabinda (CA) & 10 & Hardap (HAR) & 6 \\
Cuando Cubango (CC) & 3 & Karas (KAR) & 12 \\
Cuanza Norte (CN) & 11 & Kavango East (KAV) & 6 \\
Cuanza Sul (CS) & 9 & Kavango West (KAV) & 4 \\
Cunene (CU) & 5 & Khomas (KHO) & 6 \\
Huambo (HA) & 22 & Kunene (KUN) & 18 \\
Huíla (HI) & 3 & Ohangwena (OHA) & 1 \\
Luanda (LA) & 1 & Omaheke (OMA) & 5 \\
Lunda Norte (LN) & 1 & Omusati (OMU) & 5 \\
Lunda Sul (LS) & 7 & Oshana (OSH) & 7 \\
Malanje (MA) & 2 & Oshikoto (OKO) & 12 \\
Moxico (MO) & 14 & Otjozondjupa (OTJ) & 5 \\
Namibe (NA) & & Zambezi (ZAM) & \\
\hline
\end{tabular}

restricted species of Barleria occur here including $B$. antunesii, B. crabbeoides and B. newtonii. This area also holds the highest number of globally threatened taxa of Barleria per half-degree-square within the study region (three: B. crabbeoides, B. newtonii and

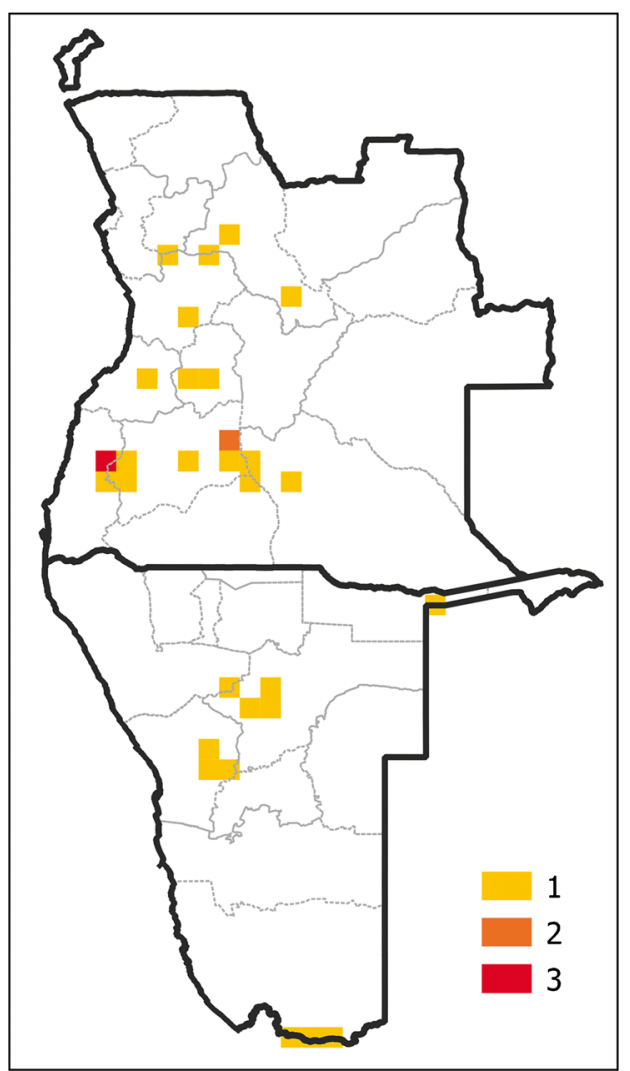

Fig. 15. Distribution of threatened species (Vulnerable, Endangered and Critically Endangered) of Barleria in Angola and Namibia; species per half-degree-square.
B. violascens var. humpatana; Fig. 15) and is notable for having high species richness across infrageneric taxa of Barleria (Fig. 16). Hence, whilst the importance of this region may be somewhat exaggerated by the intensive botanical exploration that has taken place, there is no doubt that this is a centre of diversity and endemism for Barleria as well as for floristic endemism more generally.

The desert lowlands between Moçâmedes and Lubango (b in Fig. 14G), which represent the northern-most extent of the Kaokoveld Centre of Endemism (see below), are also noteworthy for holding a small number of endemic and rangerestricted taxa of Barleria, including $B$. deserticola and B. gossweileri. This desert region has long been noted as an area of significant botanical interest (Teixeira 1968), with high numbers of endemic taxa. The transport corridors between Moçâmedes and Lubango are particularly well collected and significant taxon richness in Barleria is noted from this area; it is likely that neighbouring half-degree-squares will also hold a similarly high number of species once they are more thoroughly botanised. This desert region holds a number of other endemic Acanthaceae, including Justicia eriniae I.Darbysh., Petalidium glandulosum S.Moore, $P$. lepidagathis S.Moore, $P$. rupestre S.Moore as well as being the only known location (two known populations) for the monospecific genus Mcdadea: M. angolensis E.Tripp \& I.Darbysh. (Darbyshire et al. 2019a; Darbyshire \& Goyder 2019; Tripp \& Darbyshire 2020; E. A. Manzitto-Tripp \& K. Dexter, unpubl. data).

A recent analysis of the distribution of Angolan endemic species of Euphorbia, the largest endemic plant radiation in Angola, revealed similar patterns of species richness to that in Barleria, with the Lubango Highlands and the Angolan Kaokoveld Desert highlighted as areas 


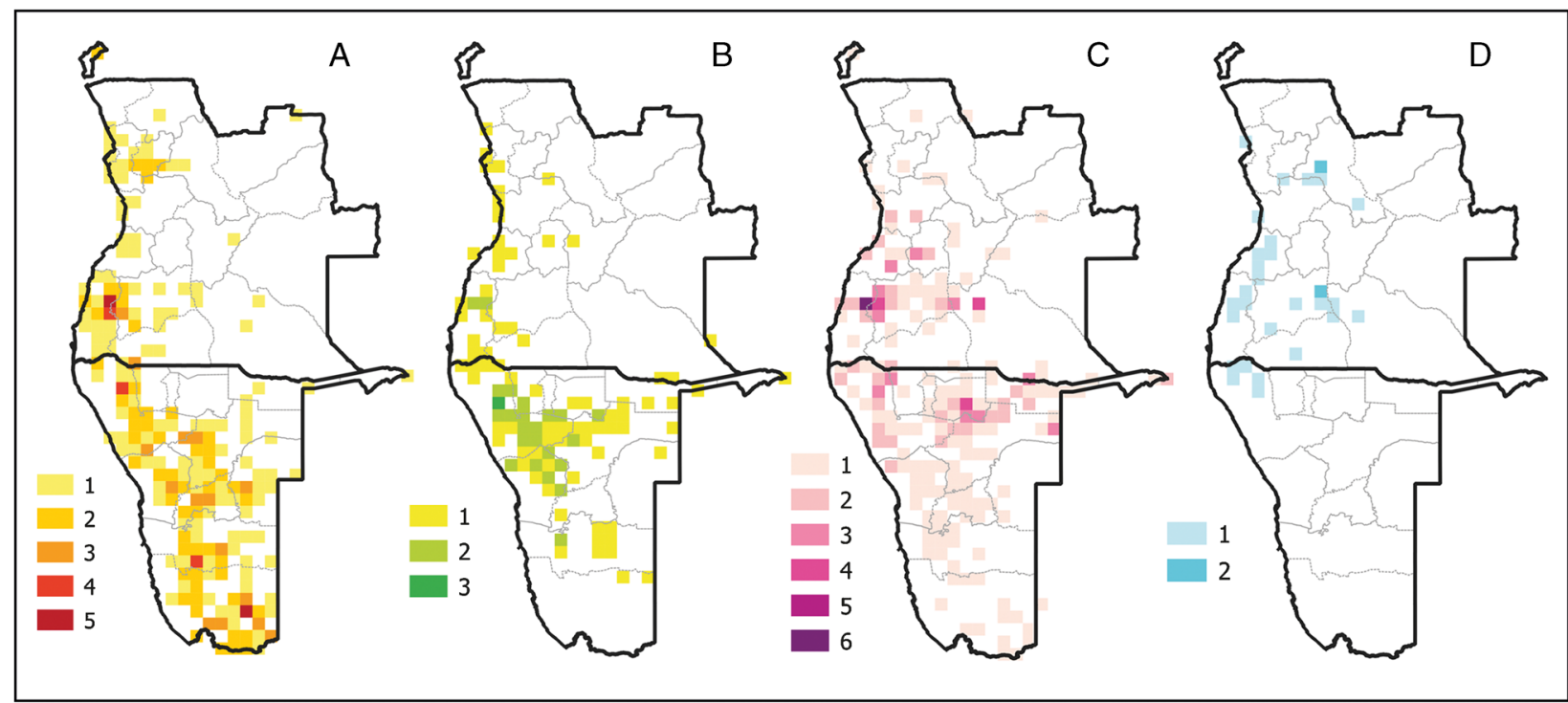

Fig. 16. Distribution of infrageneric taxa of Barleria in Angola and Namibia; taxon richness per half-degree-square. A subg. Barleria; B - D subg. Prionitis; B sect. Prionitis; C sect. Somalia; D sect. Stellatohirta.

with highest species richness and so of high conservation importance (Frazão et al. 2019). Parallel radiations within Acanthaceae, e.g., in the genus Petalidium, further exemplify the botanical importance of these two regions. The Lubango Highlands have also been noted as a critical area for diversity in the legume genus Vigna Savi, contributing significantly to the gene pool for Crop Wild Relatives of important crop species such as the cowpea, V. unguiculata (L.) Walp. (Catarino et al. 2021).

\section{Namibia}

Namibia has much more complete botanical coverage than Angola, and this may partially explain the appearance of generally higher species richness per half-degree-square than in Angola (Fig. 14C) despite its lower total number of species (Table 3). There are still many under-collected areas in Namibia, such as the more inaccessible mountains of the extreme northwest, and areas of the Namib Desert particularly between Gobabeb and Lüderitz. Of these, northwestern Namibia is likely to host as-yet undiscovered diversity of Acanthaceae whereas the lowland Namib, with its much more succulent flora having affinities to the Succulent Karoo of South Africa, is likely to be species poor for Acanthaceae (E. A. Manzitto-Tripp \& K. Dexter, pers. obs.). This is reflected in the low number of species of Barleria and other Acanthaceae taxa in the Sperrgebiet diamond mining restriction zone, recently declared the Tsau Khaeb National Park in the southwest of Namibia, which has received better botanical coverage than the areas north of Lüderitz (F. M. Chase, pers. obs.).

Despite these knowledge gaps, some clear distributional patterns are discernible. Of particular note, the western portions of Namibia, and in particular the Kaokoveld and the higher elevation areas of the Namib Desert, are clearly more rich in Barleria and other Acanthaceae than are the eastern Kalahari Desert and fringes. This, at least in part, reflects the high landscape and geological complexity and relatively high soil fertility in the west, all of which are favourable to Acanthaceae diversity in general (Tripp \& Luján 2018). This is in contrast to the relatively uncomplex, plain-like landscape and the deep, leached sands (arenosols) with low nutrient content in the Kalahari Basin (Mendelsohn et al. 2002). The Namibian Kaokoveld (c in Fig. 14C) is a complex arid region with much variation in relief and geology resulting in varied micro-habitats and xeric vegetation types. This area holds several endemic or range-restricted species of Barleria, including B. damarensis, B. grootbergensis and B. meeuseana P.G.Mey. In addition, as in the Lubango Highlands, this region has high richness across infrageneric taxa of Barleria (Fig. 16). The Kaokoveld is well-documented as a centre of plant diversity and endemism (Hilton-Taylor 1994; Maggs et al. 1998; van Wyk \& Smith 2001; Craven 2009), with high numbers of endemics noted in the Acanthaceae as well as in Apocynaceae, Burseraceae (with a major radiation of Commiphora Jacq.), Capparaceae, Cucurbitaceae, Fabaceae, Poaceae and Vitaceae (van Wyk \& Smith 2001). Brandberg in Erongo Region, the highest mountain in Namibia, is included as a southern outlier of the Kaokoveld Centre of Endemism by van Wyk \& Smith (2001). It is known for its point-endemism, including in Acanthaceae the striking Ruellia brandbergensis Kers and Peristrophe namibiensis Balkwill subsp. brandbergensis Balkwill (Balkwill et al. 1988; Tripp \& Dexter 2012). Whilst there 
are no endemics of Barleria on Brandberg itself, the mountains in the vicinity, particularly to the west $(d$ in Fig. 14C), are relatively species rich and this is a key area for two range-restricted species, B. merxmuelleri P.G.Mey. and B. solitaria P.G.Mey., both of which can be considered southern Kaokoveld endemics.

Elsewhere in Namibia, the area in the vicinity of Outjo and Otjiwarongo on the border of Kunene and Otjozondjupa Regions (e on Fig. 14C) is rich in species of Barleria. This is a particularly wellbotanised area, easily accessible via main transport routes, and so may be affected by collecting bias. Regardless, this area does include some rangerestricted species of Barleria including the apparently endemic B. violacea from Outjo, and B. jubata S.Moore, which is restricted to the sandstones of Waterberg and neighbouring hills.

In southern Namibia, the Gariep Centre of Plant Endemism, which is shared with the Northern Cape of South Africa and which includes the famous Richtersveld (van Wyk \& Smith 2001), is not as species rich for Barleria as is the Kaokoveld, but is notable for containing several endemics, including B. craveniae I.Darbysh. and B. papillosa T.Anderson, the latter of which is globally threatened (Fig. 15). The Gariep Centre, a part of the Succulent Karoo, is, like the Kaokoveld, notable for its landscape and geological complexity. Its endemic flora contains a high succulent component, most notably in the Aizoaceae: Mesembryanthemoideae, although nonsucculent endemics are also plentiful (van Wyk \& Smith 2001). The mountainous parts of this Centre still have much to discover; for example an as yet undescribed species of Petalidium is known from this region and the rare and striking succulent subshrub Sarcocaulon herrei L.Bolus (= Monsonia herrei (L.Bolus) F.Albers; Geraniaceae) was recently recorded for the first time in Namibia from here (Nanyeni \& Nzuma 2018). Higher species richness of Barleria per half-degree-square is noted further east in southeast Karas Region (f in Fig. 14C) in the Karas Dwarf Shrubland vegetation type of Mendelsohn et al. (2002), but this area does not hold any narrow-endemic species in the genus. This area is under-collected but is known to have an interesting flora, with much still to discover. For example, the striking geophyte Eriospermum paradoxum (Jacq.) Ker Gawl. (Asparagaceae) has recently been found in Namibia for the first time in the Warmbad area, a proposed Important Plant Area (F. M. Chase, pers. obs).

\section{Distribution of infraspecific taxa of Barleria in Angola and Namibia}

Distribution patterns vary significantly between the monophyletic subgenera and sections of Barleria (Fig. 16). Subg. Barleria is richest in the deserts and xeric shrublands of the Namib Desert and Kaokoveld Centre of Endemism and accounts for most of the endemism in Namibia (Fig. 16A). Sect. Somalia, on the other hand, becomes more diverse and abundant in the fire-prone miombo woodlands and savannas rich in geoxylic suffrutices in Western Angola and northeastern Namibia (Fig. 16C), the southwestern portion of the Zambesian Centre of Endemism. This is also reflected by differences in growth habit: the majority of species in subg. Barleria are shrublets whilst many of the species in sect. Somalia are suffruticose with a woody base and rootstock and with annual aboveground growth. It is notable, however, that species richness in both these sections peaks in the Lubango Highlands of Angola. Clearly, this area must be considered a conservation priority for Barleria and, given that the natural habitats of this area are highly threatened by human activities, the Lubango Highlands must be considered a high priority for formal protection and biodiversity management.

\section{Acknowledgments}

The Namibian component of this research, including fieldwork and research visits to WIND herbarium, was primarily supported by the Southern African Science Service Centre for Climate Change and Adaptive Land Management (SASSCAL) programme, Task 060 "Establish and Improve baseline inventories for spatial data and biodiversity - Flora of Namibia Project". We thank Mrs Esmerialda Strauss, Head of the National Botanical Research Institute (NBRI) of Namibia, for inviting and overseeing our participation in this programme and for kindly facilitating the research visits of I. Darbyshire and E. A. Manzitto-Tripp to Namibia between 2010 and 2015. Ezekeil Kwembeya of the University of Namibia (formerly of NBRI) is also thanked for his input and early facilitation of this research. Fieldwork in Namibia by E. Tripp and colleagues was supported by a U.S. National Science Foundation grant DEB-0919594 to E. Tripp \& L. McDade. Additional fieldwork in Namibia as well as fieldwork in Angola was supported by NSF grants DEB1354963 and DEB-1355138 to E. Tripp and L. McDade, and funding from the Systematics Association, the British Ecological Society, and the Moray Endowment Fund of the University of Edinburgh. We thank the Ministry of Environment and Tourism in Namibia for granting our research permits in that country, and the Ministry of Agriculture of Angola for granting research permits in that country. Fernanda Lages and Francisco Gonçalves of the Instituto Superior de Ciências de Educação, Huíla, are warmly thanked for their assistance in providing access to collections from the LUBA herbarium and for logisitical support for Angolan fieldwork by E. A. Manzitto-Tripp and K. Dexter. I. Darbyshire thanks de Beers Angola Prospecting Ltd. for providing logistic support during his 2013 visit to Angola, which included a visit to the LUAI herbarium. We are 
grateful to all our fieldwork collaborators. In particular, Kyle Dexter (University of Edinburgh) has been a key collaborator on many of the fieldtrips through Namibia and Angola and is thanked for his extensive contributions. Leevi Nanyeni of NBRI is thanked for his excellent contribution to the Namibian fieldwork; Leevi was also a great help with addressing various queries regarding specimens in the WIND herbarium. We would also like to thank the following curators and research staff for providing access to the herbarium collections of Barleria at their institutions: Robert Vogt (B), Ranee Prakash and Jacek Wajer (BM), Maria Romeiras and Maria Cristina Duarte (LISC), Ana Isabel Correia (LISU), Esperança da Costa (LUAI), Andreas Fleischmann and Hans-Joachim Esser (M), Alpheus Mothapo and Hester Steyn (PRE), Christopher Chapano and Anthony Mapaura (SRGH) and Hendrina Hasheela, David Aiyambo and Leevi Nanyeni (WIND). I.D. wishes to thank in particular Dr Hester Steyn of the South African Biodiversity Research Institute for facilitating his visit to the PRE herbarium in September 2019. We thank David Goyder of the Royal Botanic Gardens, Kew for seeking out Acanthaceae during his various expeditions to Angola over the past few years and for his helpful advice on the phytogeography and botanical history of that fascinating country. Patricia Craven has helpfully provided information on species distributions and collections of Barleria in Namibia. Equally, Willem Froneman of the South African National Biodiversity Institute (SANBI) has provided useful information on and photographs of the southern African species of Barleria. We are again highly grateful to Andrew Brown for the excellent illustrations of the newly described species. Finally, we thank Pedro Beja, Barbara Ditsch, Francisco Gonçalves, David Goyder, Fernanda Lages, Teresa Leyens and Warren McCleland for granting permission to use their photographs of Barleria species and Dr Stefan Dressler of the Forschungsinstitut Senckenberg for facilitating access to images of Barleria via the African Plants - a Photo Guide website.

Open Access This article is licensed under a Creative Commons Attribution 4.0 International License, which permits use, sharing, adaptation, distribution and reproduction in any medium or format, as long as you give appropriate credit to the original author(s) and the source, provide a link to the Creative Commons licence, and indicate if changes were made. The images or other third party material in this article are included in the article's Creative Commons licence, unless indicated otherwise in a credit line to the material. If material is not included in the article's Creative Commons licence and your intended use is not permitted by statutory regulation or exceeds the permitted use, you will need to obtain permission directly from the copyright holder. To view a copy of this licence, visit http://creativecommons.org/ licenses/by/4.0/.

\section{References}

Aguiar, F. Q. B. \& Diniz, A. C. (1972). Carta de Vegetação do Planalto Ocidental da Cela: Estudo Interpretativo. Série Científica $\mathrm{N}^{\circ}$ 26. Instituto de Investigação Agronómica de Angola, Nova Lisboa [Huambo].

Albuquerque, S., Brummitt, R. K. \& Figueiredo, E. (2009). Typification of names based on the Angolan collections of Friedrich Welwitsch. Taxon 58: $641-646$.

\& Correia, A. I. (2009). The Welwitsch collections; Iter Angolense (1853 - 1860) at LISU. In: X. van der Burgt, J. van der Maesen \& J.-M. Onana (eds), Systematics and Conservation of African Plants. Proceedings of the $18^{\text {th }}$ AETFAT Congress, Yaoundé, Cameroon, pp. 787 - 790. Royal Botanic Gardens, Kew.

Anderson, T. (1863). An enumeration of the species of Acanthaceae from the continent of Africa and the adjacent islands, J. Proc. Linn. Soc, Bot. 7: 13 - 54.

Balarin, M. G., Brink, E. \& Glen, H. F. (1999). Itinerary and specimen list of M. A. Pocock's botanical collecting expedition in Zambia and Angola in 1925. Bothalia 29: 169 - 201.

Balkwill, M. J. \& Balkwill, K. (1997). Delimitation and infra-generic classification of Barleria (Acanthaceae). Kew Bull. 52: 535 - 573.

\& _ (1998). A preliminary analysis of distribution patterns in a large, pantropical genus, Barleria L. (Acanthaceae). J. Biogeogr. 25: 95 - 110. , Getliffe-Norris, F. \& Balkwill, M.-J. (1988). Taxonomic studies in the Acanthaceae: The Peristrophe grandibracteata complex. S. African J. Bot. 54: $47-54$.

Benoist, R. (1950). Quelques Acanthacées des colonies Portugaises Africanes. Bol. Soc. Brot. Sér. 2, 24: 5 39.

Brummitt, R. K. \& Seyani, J. H. (1978). Two new species of Barleria (Acanthaceae) from tropical Africa. Kew Bull. 32: 721 - 726.

Catarino, S., Rangel, J., Darbyshire, I., Costa, E., Duarte, M. C. \& Romeiras, M. M. (2021). Conservation priorities for African Vigna species: Unveiling Angola's diversity hotspots. Glob. Ecol. Conserv. 25: e01415. https://doi.org/10.1016/j.gecco.2020.e01415.

Chisingui, A. V., Gonçalves, F. M. P., Tchamba, J. J., Camônga Luis, J., Rafael, M. F. F. \& Alexandre, J. L. M. (2018). Vegetation survey of the woodlands of Huíla Province. In: Climate Change and Adaptive Land Management in Southern Africa - assessments, 
changes, challenges, and solutions, pp. 426 - 437. Klaus Hess Publishers, Göttingen and Windhoek.

Clarke, C. B. (1884). Barleria. In: J. D. Hooker (ed.), Flora of British India 4: 482 - 490. L. Reeve \& Co., London.

(1899). Barleria. In: W. T. Thiselton-Dyer (ed.), Flora of Tropical Africa. Vol. 5: 140 - 169. L. Reeve \& Co., London.

(1901). Barleria. In: W. T. Thiselton-Dyer (ed.), Flora Capensis. Vol. 5 (Pt. 1): 44 - 55. L. Reeve \& Co., London.

Comito, R. P. (2019). A RADseq phylogeny of Barleria (Acanthaceae) resolves fine-scale relationships. Unpubl. M.Sc. Thesis, California State University, Long Beach.

Compton, R. H. (1976). The Flora of Swaziland. J. S. African Bot., Suppl. Vol. 11.

Craven, P. (ed.) (1999). A checklist of Namibian plant species. South African Botanical Diversity Network Report No. 7, SABONET, Windhoek.

(ed.) (2009). Phytogeographic study of the Kaokoveld Centre of Endemism. Ph.D. thesis, University of Stellenbosch. https://scholar.sun.ac.za/handle/ 10019.1/1325.

Dalzell, N. A. (1850). Contributions to the botany of Western India [in part]. Hooker's J. Bot. Kew Gard. Misc. 2: 336 - 344.

Darbyshire, I. (2008). New species in Barleria sect. Stellatohirta (Acanthaceae) from Africa. Kew Bull. 63: $261-268$.

(2009). A reassessment of the status of Barleria sect. Cavirostrata (Acanthaceae) in tropical Africa, with a new species, $B$. richardsiae, described from the Tanzania-Zambia border region. Kew Bull. 63: $601-611$.

(2010). Barleria. In: H. J. Beentje (ed.), Flora of Tropical East Africa. Acanthaceae (Part 2), pp. $325-$ 442. Royal Botanic Gardens, Kew.

(2015). Barleria. In: J. R. Timberlake \& E. S. Martins (eds), Flora Zambesiaca Vol. 8 (6): 37 - 122. Royal Botanic Gardens, Kew.

Fisher, A., Kiel, C. A. \& McDade, L. A. (2019b). Phylogenetic relationships among species of Barleria (Acanthaceae, Lamiales): molecular data reveal complex patterns of morphological evolution and support a revised classification. Taxon 68: $92-111$.

\& Goyder, D. (2019). Notes on Justicia sect. Monechma (Acanthaceae) in Angola, including two new species. Blumea 64: 97 - 107.

, Kiel, C. A., Astroth, C. M., Dexter, K. G., Chase, F. M. \& Tripp, E. A. (2020a). Phylogenomic study of Monechma reveals two divergent plant lineages that are ecologically important in the African savanna and succulent biomes. Diversity 12 (6): 237 (25 pp.).

\& Luke, Q. (2016). Barleria mirabilis (Acanthaceae): a remarkable new tree species from west Tanzania. Kew Bull. 71-13: 1 - 6.
\& Ndangalasi, H. J. (2009). Three new species of Barleria sect. Somalia (Acanthaceae) from the miombo woodlands of western Tanzania. J. E. Afr. Nat. Hist. Soc. Natl. Mus. 97: 123 - 134.

, Tripp, E. A. \& Chase, F. M. (2019a). A taxonomic revision of Acanthaceae tribe Barlerieae in Angola and Namibia. Part 1. Kew Bull. 74-5: 1 - 85.

Tripp, E. A., Crawford, F. M. \& Barker, A. (2020b). Barleria crabbeoides. The IUCN Red List of Threatened Species 2020: e.T154071884A154074759. https:// doi.org/10.2305/IUCN.UK.20203.RLTS.T154071884A154074759.en. [accessed 5 March 2021]

\& Dexter, K. G. (2012). A new species and a revised record in Namibian Barleria (Acanthaceae). Kew Bull. 67: 759 - 766.

Da Silva, D. F., Cahali, A. E., Gomes, F. A., Tchamba, J. J. \& Gonçalves, F. M. (2020). Caracterização da diversidade de espécies do Parque Nacional do Bicuar e implicações para a gestão e conservação da biodiversidade / Characterization of species diversity in the Bicuar National Park and implications for the management and conservation of biodiversity. Revista Internacional de Educação, Saúde e Ambiente 2020, Vol. 3 (1): 46 - 58.

De Wildeman, É. (1903). Etudes sur la Flore du Katanga. Acanthaceae. Ann. Mus. Congo Belge, Bot. sér. 4 (3): 134 - 160.

Dold, T. \& Kelly, J. (2018). Bushmen, Botany and Baking Bread. Mary Pocock's record of a journey with Dorothea Bleek across Angola in 1925. NISC, Grahamstown.

Dressler, S., Schmidt, M. \& Zizka, G. (2014+) [continuously updated]. African Plants - a photo guide. Forschungsinstitut Senckenberg, Frankfurt/Main, Germany. Available at: www.africanplants.senckenberg.de. [accessed 26 Feb. 2020]

Engler, A. (1888). Plantae Marlothianae. Ein Beitrag zur Kenntnis der Flora Südafrikas. Bot. Jahrb. Syst. 10: $242-285$.

Exell, A. W. \& Gonçalves, M. L. (1973). A statistical analysis of a sample of the flora of Angola. Garcia de Orta, Sér. Bot. 1: 105 - 128.

Figueiredo, E. (2008). The Rubiaceae of Angola. Bot. J. Linn. Soc. 156: 537 - 638.

\& Smith, G. F. (2008). Plants of Angola / Plantas de Angola. Strelitzia 22.

Frazão, R., Catarino, S., Goyder, D., Darbyshire, I., Magalhães, M. F. \& Romeiras, M. M. (2019). Species richness and distribution of the largest plant radiation of Angola: Euphorbia (Euphorbiaceae). Biodivers. Conserv. 29: 187 - 206.

Godlee, J. L., Gonçalves, F. M., Tchamba, J. J., Chisingui, A. V., Muledi, J. I., Shutcha, M. N., Ryan, C. M., Brade, T. K. \& Dexter, K. G. (2020). Diversity and structure of an arid woodland in southwest Angola, with comparison to the wider miombo ecoregion. Diversity 12 (4): 140 (20 pages). 
Goyder, D. J., Barker, N., Bester, S. P., Frisby, A., Janks, M. \& Gonçalves, F. M. P. (2018). The Cuito catchment of the Okavango system: a vascular plant checklist for the Angolan headwaters. PhytoKeys 113: $1-31$.

\& Gonçalves, F. M. P. (2019). The Flora of Angola: Collectors, Richness and Endemism. In: B. J. Huntley, V. Russo, F. Lages \& N. Ferrand (eds), Biodiversity of Angola. Science and Conservation: A Modern Synthesis, pp. 79 - 96. Springer, Cham.

Heine, H. (1966). Flore du Gabon 13. Acanthacées. Muséum National d'Histoire Naturelle, Paris.

Hiern, W. P. H. (1900). Catalogue of the African plants collected by Friedrich Welwitsch in 1853 - 1861. Dicotyledons, part IV Lentibulariaceae to Ceratophylleae. British Museum (Natural History), London.

Hilton-Taylor, C. (1994). The Kaokoveld. pp. 201 203 in: S. D. Davis, V. H. Heywood \& A. C. Hamilton (eds), Centres of plant diversity. A guide and strategy for their conservation. Vol. 1. IUCN Publications Unit, Cambridge.

Hooker, J. D. (1870). Barleria mackenii. Mr. McKen's Barleria. Bot. Mag. 96: t. 5866.

Huntley, B. J., Beja, P., Vaz Pinto, P., Russo, V., Veríssimo, L. \& Morais, M. (2019b). Biodiversity Conservation: History, Protected Areas and Hotspots. In: B. J. Huntley, V. Russo, F. Lages \& N. Ferrand (eds), Biodiversity of Angola. Science and Conservation: A Modern Synthesis, pp. 495 - 512. Springer, Cham.

, Russo, V., Lages, F. \& Ferrand, N. (eds) (2019a). Biodiversity of Angola. Science and Conservation: A Modern Synthesis. Springer, Cham.

IUCN (2012). IUCN Red List Categories and Criteria. Version 3.1. Second Edition. IUCN Species Survival Commission, Gland \& Cambridge.

IUCN Standards and Petitions Committee (2019). Guidelines for Using the IUCN Red List Categories and Criteria. Version 14. Prepared by the Standards and Petitions Committee. Available at: http:// w w w . i u c n red lis t . org / d o c u m en t s / RedListGuidelines.pdf [accessed 20 April 2020]

Klaassen, E. \& Kwembeya, E. (eds) (2013). A checklist of Namibian indigenous and naturalised plants. Occasional Contributions No. 5, National Botanical Research Institute, Windhoek.

Klopper, R. R., Chatelain, C., Bänninger, V., Habashi, C., Steyn, H. M., de Wet, B. C., Arnold, T. H., Gautier, L., Smith, G. E. \& Spichiger, R. (2006). Checklist of the flowering plants of sub-Saharan Africa. An index of accepted names and synonyms. South African Botanical Diversity Network Report No. 42, SABONET, Pretoria.

Lindau, G. (1894). Acanthaceae africanae II. Bot. Jahrb. Syst. 20: $1-76$.

(1895a). Acanthaceae. In: A. Engler \& K. Prantl (eds), Nat. Pflanzenfam. 4 (IIIB): 274 - 354. W. Engelmann, Leipzig. (1895b). Acanthaceae africanae III. Bot. Jahrb. Syst. 22: 112 - 127.

(1896). Contribuzioni alla conoscenza della flora dell'Africa orientale. V. Acanthaceae somalenses a DD. L. Bricchetti-Robecchi et Dr. Riva in Harar et in Somalia lectae. Ann. Ist. Bot. Roma 6: $67-83$.

Linder, H. P. (2001). Plant diversity and endemism in sub-Saharan tropical Africa. J. Biogeogr. 28: 169 - 182.

, de Klerk, H. M., Born, J., Burgess, N. D., Fjeldså, J. \& Rahbek, C. (2012). The partitioning of Africa: statistically defined biogeographical regions in subSaharan Africa. J. Biogeogr. 39: 1189 - 1205.

Maggs, G. L., Craven, P. \& Kolberg, H. H. (1998). Plant species richness, endemism, and genetic resources in Namibia. Biodivers. Conserv. 7: $435-$ 446.

Makholela, T. (2008). Acanthaceae. In: E. Figueiredo \& G. F. Smith (eds), Plants of Angola / Plantas de Angola. Strelitzia 22: 21 - 25.

Mendelsohn, J. M. (2019). Landscape changes in Angola. In: B. J. Huntley, V. Russo, F. Lages \& N. Ferrand (eds), Biodiversity of Angola. Science and Conservation: A Modern Synthesis, pp. 123 - 137. Springer, Cham.

Jarvis, A., Roberts, C. \& Robertson, T. (2002). Atlas of Namibia. A portrait of the land and its people. Ministry of Environment \& Tourism and David Philip, Cape Town.

\& Mendelsohn, S. (2018). Sudoeste de Angola: Um retrato da terra e da vida / South West Angola: a portrait of land and life. Onde a Ciência é Arte, Natural History and Science Museum. Arte e Ciência, Porto.

Meyer, P. G. (1957). Beitrag zur kenntris der Acanthaceen SüdwestAfrikas. Mitt. Bot. Staatssamml. München 2: 368 - 385.

(1968). 130. Acanthaceae. In H. Merxmüller (ed.), Prodromus einer Flora von Südwestafrika. J. Cramer, Lehre.

Milne-Redhead, E. (1940). Acanthaceae. In: [Various Authors] Tropical African plants XVIII [cont.]. Bull. Misc. Inform., Kew 1940: 64 - 65.

Moore, S. le (1880). Enumeratio Acanthacearum Herbarii Welwitschiani Angolensis. J. Bot. 18: 193 199, 225 - 233, 265 - 270, 307 - 314, $340-342 \& 362$ 366.

(1902a). Alabastra Diversa. Part X. Two imperfectly known species of Barleria. J. Bot. 40: 407 - 408 . (1902b). Mr T. Kässner's British East African Plants. J. Bot. 40: 339 - 346.

(1902c). Alabastra Diversa. Part IX. New Acanthaceae from tropical Africa. J. Bot. 40: 305-310. (1907a). Alabastra Diversa. Part XIV. New or little-known African Gamopetalae. J. Bot. 45: 41 - 53 \& $87-98$.

(1907b). Alabastra Diversa. Part XV. 1. New or rare Acanthaceae from German South-West Africa. J. Bot. 45: 226 - 233. 
(1911). Alabastra Diversa. Part XXI. Acanthaceae Africanae Novae. J. Bot. 49: 293 - 298 \& 305 - 313. (1918). Alabastra Diversa. Part XXVIII. Plantae Rogersianae III. J. Bot. 56: 4 - 11 \& 36 - 40.

(1930). Mr John Gossweiler's plants from Angola and Portuguese Congo. Acanthaceae. J. Bot. 68, Suppl. II: 126 - 139 .

Munday, J. (1983). The distribution of Monechma (Acanthaceae) species in southern Africa. Bothalia 14: $575-578$.

(1995). Monechma. In: O. A. Leistner (ed.), Flora of Southern Africa Vol. 30 (3): 47 - 61. National Botanical Institute, Pretoria.

Nanyeni, L. \& Nzuma, T. M. (2018). New record of Monsonia herrei for Namibia. Bothalia 48: a2342.

Obermeyer, A. A. (1933). A revision of the South African species of Barleria. Ann. Transvaal Mus. 15: $123-180$.

Oliver, D. (1886). Somalia diffusa. Hooker's Icon. Pl. 16: t.1528.

Palacios, G., Lara-Gomez, M., Márquez, A., Vaca, J. L., Ariza, D. Lacerda, V. \& Navarro-Cerrillo, R. M. (2015). Spatial dynamic and quantification of deforestation and degradation in miombo forest of Huambo Province (Angola) during the period 2002 - 2015. SASSCAL Project Proceedings, Huambo, Angola. Available at: http:/ /data.sasscal.org/ metadata/view.php?view=doc_documents\&id=2966 [accessed 15 April 2019]

Pickering, H. \& Roe, E. (2009). Wild Flowers of the Victoria Falls Area. Helen Pickering [self-published], London.

Schinz, H. (1916). Beiträge zur kenntnis der afrikanischen flora (XXVII). Vierteljahrsschr. Naturf. Ges. Zürich 61: 431 - 461.

Shendage, S. M. \& Yadav, S. R. (2010). Revision of the genus Barleria (Acanthaceae) in India. Rheedea 20: 81 - 130.

Sosef, M. S. M. (2006). Acanthaceae. pp. 35 - 43 in: M. S. M. Sosef et al. (eds), Check-list des plantes vasculaires du Gabon / Checklist of Gabonese vascular plants. Scripta Bot. Belg. 35.

Steyn, H. M., von Staden, L., Bellstedt, D. U. \& van Wyk, A. E. (2019). Notes on the phytogeography and conservation status of the genus Acanthopsis (Acantheae, Acanthaceae). Phytotaxa 415: 157 - 178.

Suessenguth, K. \& Merxmüller, H. (1955). Taxa praecipae Africana. Mitt. Bot. Staatssamml. München 12: 67 - 83.

Thomas, D. S. G. \& Shaw, P. A. (1991). The Kalahari environment. Cambridge University Press, Cambridge.

Tripp, E. A. \& Darbyshire, I. (2017). Phylogenetic relationships among Old World Ruellia L.: a new classification and reinstatement of the genus Dinteracanthus Schinz. Syst. Bot. 42: 470 - 483.

\& __ (2020). Mcdadea: A new genus of Acanthaceae endemic to the Namib Desert of Southwestern Angola. Syst. Bot. 45: 200 - 211. https://doi.org/10.1600/ 036364420X15801369352478

\& Dexter, K. G. (2012). Taxonomic novelties in Namibian Ruellia (Acanthaceae). Syst. Bot. 37: 1023 1030.

\& Luján, M. (2018). Venezuelan Ruellia (Acanthaceae): A Monograph. Mem. New York Bot. Gard. 119: 1 - 76.

, Tsai, Y.-H. E., Zhuang, Y. \& Dexter, K. (2017). RADseq dataset with $90 \%$ missing data fully resolves recent radiation of Petalidium (Acanthaceae) in the ultra-arid deserts of Namibia. Ecol. Evol. 7: 7920 7936.

Turland, N. J., Wiersema, J. H., Barrie, F. R., Greuter, W., Hawksworth, D. L., Herendeen, P. S., Knapp, S., Kusber, W.-H., Li, D.-Z., Marhold, K., May, T. W., McNeill, J., Monro, A. M., Prado, J., Price, M. J. \& Smith, G. F. (eds) (2018). International Code of Nomenclature for algae, fungi, and plants (Shenzhen Code) adopted by the Nineteenth International Botanical Congress Shenzhen, China, July 2017. Regnum Veg. 159. Koeltz, Glashütten.

Van Wyk, A. E. \& Smith, G. F. (2001). Regions of Floristic Endemism in Southern Africa. A review with emphasis on succulents. Umdaus Press, Hatfield.

Vaz Pinto, P. (2019). The Giant Sable Antelope: Angola's National Icon. In: B. J. Huntley, V. Russo, F. Lages \& N. Ferrand (eds), Biodiversity of Angola. Science and Conservation: A Modern Synthesis, pp. 471 - 491. Springer, Cham.

Wawra, H. \& Peyritsch, J. (1860). Sertum benguelense. Sitzungsber. Acad. Wien, Math.-Nat. 38: 543 - 586.

Welman, W. G. (2003). Acanthaceae. In: G. Germishuizen \& N. L. Meyer (eds), Plants of southern Africa: an annotated checklist. Strelitzia 14: $92-106$.

White, F. (1983). Vegetation of Africa. A Descriptive Memoir to Accompany the UNESCO/AETFAT/UNSO Vegetation Map of Africa. UNESCO, Paris.

\section{Publisher's Note}

Springer Nature remains neutral with regard to jurisdictional claims in published maps and institutional affiliations. 